Danmarks Geologiske Undersøgelse.

II. Række. Nr. 74.

\title{
Nogle Forekomster
}

af

\section{Arktisk Strukturmark (Brodelboden)}

bevarede i danske Istidsaflejringer.

\author{
Af \\ Aksel Nørvang.
}

Med 28 Figurer i Teksten og 1 Tavle.

With an English Summary.

I Kommission hos

C. A. Reitzels Forlag

Axel Sandal

København 1946.

Pris: $4 \mathrm{Kr}$. 
Danmarks Geologiske Undersøgelse.

II. Række. Nr. 74.

\title{
Nogle Forekomster
}

af

\section{Arktisk Strukturmark (Brodelboden)}

bevarede i danske Istidsaflejringer.

\author{
Af \\ Aksel Nørvang.
}

Med 28 Figurer i Teksten og 1 Tavle.

With an English Summary.

I Kommission hos

C. A. Reitzels Forlag

Axel Sandal

København 1946. 


\section{Indholdsfortegnelse.}

Side

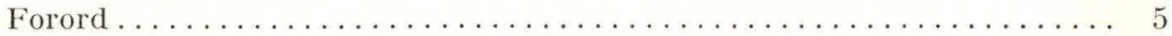

Tidligere Undersøgelser . . . . . . . . . . . . . . . . . . . 7

Beskrivelse af de vigtigste Lokaliteter . . . . . . . . . . . . 13

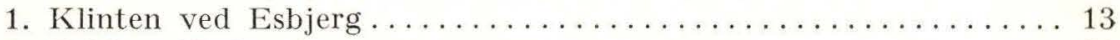

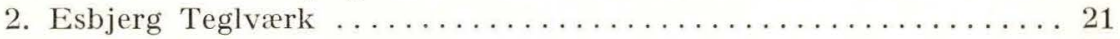

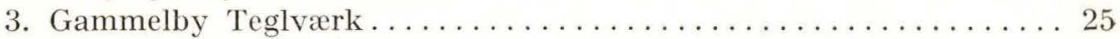

4. Lergrav ved Maade........................ 25

5. Teglværk i Bramming Stationsby ................ 26

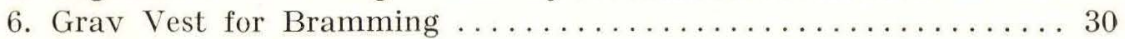

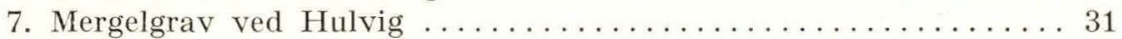

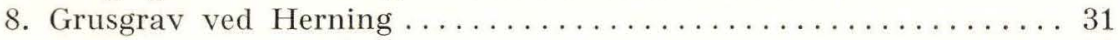

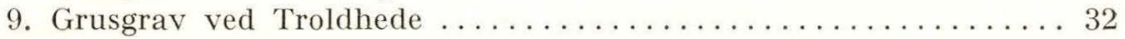

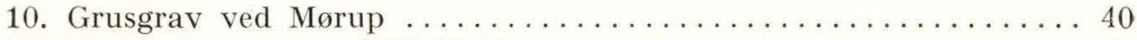

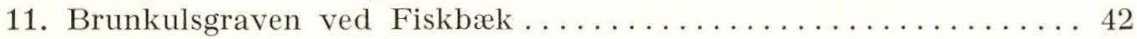

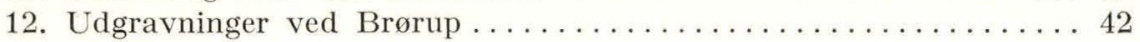

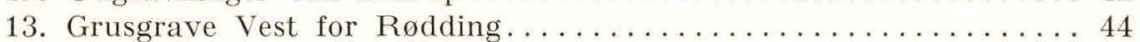

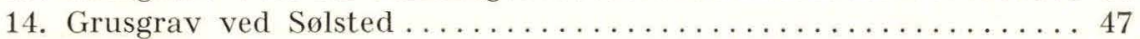

15. Grusgrav i Møgeltønder . . . . . . . . . . . . . . . . . . . 49

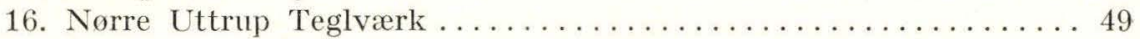

17. Grusgrav ved Hundshoved $\ldots \ldots \ldots \ldots \ldots \ldots \ldots \ldots \ldots \ldots \ldots \ldots \ldots \ldots$

18. Sandgrav ved Lundtofte, Nordsjælland . . . . . . . . . . . . 52

De danske Brodelhorisonter og den arktiske Strukturmark........ 54

De arktiske Frostfænomeners Betydning som Klimaindikatorer...... 58

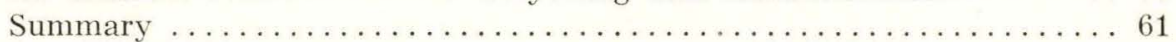

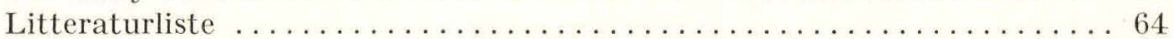




\section{Forord.}

Horeliggende Afhandling bestaar af Hovedafsnittet af min Besvarelse $\mathbb{C}$ af Universitetets Prisopgave for 1937. To mindre Afsnit er tidligere publiceret, nemlig Afsnittet om Frostspalterne i 1942 og Afsnittet om den amorfe Flydejord i 1943.

Jeg vil her benytte Lejligheden til at takke fung. Direktør for Danmarks Geologiske Undersøgelse, Statsgeolog, Dr. phil. Sigurd Hansen, der har gjort det muligt, at dette Arbejde, skønt det ikke er noget Institutionsarbejde, har kunnet blive optaget i D. G. U.'s Skrifter.

En særlig Tak skylder jeg »Student Christians Bohrs Mindelegat《 og »Japetus Steenstrups Legat《 uden hvis Støtte, jeg ikke vilde have været i Stand til at udføre Arbejdet. 


\section{Tidligere Undersøgelser.}

I 1912 forelagde E. Hons ved et Møde i Deutsche Geologische Gesellschaft nogle Iagttagelser over en Aflejring i Winterhude i den nordlige Del af Hamburg, hvori der fandtes nogle ejendommelige Lejringsforhold. Ved nogle Udgravninger var der her blottet et Profil visende Tørv og Sømergel, der opadtil var dækket af leret, stenet Sand. Mosen laa i Hovedsagen uforstyrret i det Bassin i Morænelandskabet, hvor Tørven oprindelig var aflejret; kun fandtes der oppe i de øverste to Meter stenet Sand ejendommelige Forstyrrelser, idet Sandet tilsyneladende var presset ned i Tørven i »Reder«, adskilte af smalle, nogenlunde lodret staaende Kamme af tørveagtigt Materiale. Forstyrrelserne fandtes kun ude i Midten af Mosen. Langs dens Bredder fandt man imidlertid visse Steder Lag af barnehovedstore Sten, af hvilke mange var vindslebne.

Hons hævdede, at Forstyrrelserne ikke kunde skyldes Istryk; dertil var de for ubetydelige, og i saa Tilfælde vilde det ogsaa være uforstaaeligt, at de ophørte ret pludseligt i et bestemt Niveau under Jordoverfladen. Desuden maatte man vente at finde Spor af, at Trykket havde været ensidigt. Han mente derfor, at Tørven maatte være alluvial. Det ovenliggende Sand skulde derefter være skyllet ud i Bækkenet af Regnvandet i postglacial Tid. De store Sten langs Mosens Bredder maatte endvidere være gledet ud i Bassinet fra de omliggende Bakkedrags Sider. Selve Forstyrrelserne i Sandet mente Horn maatte være en Følge af den Sammenpresning, Tørven var blevet underkastet ved Sandets Paalejring. En Forraadnelse af Tørven med samtidig Udvikling af Luftarter, der havde banet Vej op gennem Sandet, skulde efter hans Mening yderligere have begunstiget Sandets Nedsynkning i Tørven paa de mest eftergivelige Steder. Til denne Opfattelse sluttede sig under Diskussionen W. WoLfF, der fremhævede den Iagttagelse, at Stenenes Størrelse aftog jævnt fra Bredden og ind mod Bassinets Midte.

Ковrт udtalte sig imidlertid imod denne Opfattelse og mente, at det ovenliggende Sand maatte være glacigent, og i denne Antagelse fik han Støtte af GAGEL, der selv havde iagttaget lignende Forstyrrelser i Udgravninger til Kaiser-Wilhelmkanalen. Det moræneagtige Lag over Tørven 
maatte efter Koerts Mening opfattes som en Grundmoræne, der stedvis var omdannet til en Lokalmoræne af Tørv. En saa betydelig Virkning af Regnvandet, som antaget af Horn, stod efter Talerens Mening i Modstrid med, hvad man ellers kendte til Naturforholdene i postglacial Tid. Han forelagde tillige nogle Undersøgelser af BEYLE over Tørvens Indhold af Planterester. Da der heriblandt baade fandtes Rester af Picea og Brasenia, mente han med stor Sikkerhed at kunne sige, at Tørven var af interglacial Alder. Ved Undersøgelser af Faunaen i Sømergelen var MenzeL tillige naaet til det samme Resultat.

I hele 15 Aar kom disse ejendommelige Forstyrrelsers Aarsag og Dannelse til at staa som et uløst Problem. I 1927 udgav K. GRIPP imidlertid sine Undersøgelser over den recente Strukturmark paa Spitzbergen, og her i dette Arbejde udkaster han da den Tanke, at saadanne Teksturformer maatte kunde findes i Istidens Aflejringer. Han henleder i denne Forbindelse atter Opmærksomheden paa de mærkelige Lejringsforhold i Winterhude og andre Steder i Nordtyskland. Umiddelbart efter fremkommer WoLfF med en Række nye Profiler med lignende Forstyrrelser og han slutter sig ganske til GrIPps Antagelse. Samme Aar underkaster K. Keпнаск een af Wolffs Lokaliteter, nemlig Forekomsten ved Marga i Niederlausitzer Urstromtal, en nærmere Undersøgelse. Her findes ogsaa et Tørvelag overdækket af stenet Sand, hvorpaa der hviler fint Søsand. I denne Lagserie fandt han to Horisonter af saadanne Forstyrrelser.

Oprindelig havde KeILHack (1927) fundet en anden Forklaring paa disse mærkelige Fænomener, men efter at have stiftet Bekendtskab med GrIPPs Hypotese forklarer han imidlertid disse Forstyrrelser som Rester af diluviale »Brodelhorisonter«. Samtidig med KeILHACK udgiver Firbas og Grahman (1928) en indgaaende Undersøgelse af samme Lokalitet. Forfatterne fremhæver her den Lighed, der ses mellem Forstyrrelserne i denne Aflejring og Gripps Tegninger af Snit gennem »Brodelboden« paa Spitzbergen. De hævder imidlertid, at man kan finde fire eller fem forskellige Brodelhorisonter, der dog imidlertid ikke alle med Sikkerhed lader sig forfølge gennem Profilet. Ved Pollenanalyse mener Forfatterne endvidere at kunde paavise, at disse Forstyrrelser er dannet under Klimaforværringer.

Ved disse Undersøgelser var Interessen blevet vakt for Eftersøgningen af saadanne Fænomener, og i Løbet af de nærmest følgende Aar blev der offentliggjort en hel Række Iagttagelser over saadanne forstyrrede Lag. Blandt de mange interessante Arbejder maa nævnes Krekelers (1929) Undersøgelser af saadan fossil Brodelboden fra Udgravninger i Omegnen af Wiesbaden og Giessen. Om han i Virkeligheden har fundet en virkelig Brodelboden ved Wiesbaden, kan maaske betvivles. De afbildede Tegninger viser nok krøllede Lag, men ikke de ellers saa karakteristiske "Gryder", adskilte ved tynde Kamme. Tegningerne af Profil- 
væggene ved Giessen viser imidlertid interessante Ting. Her ses nemlig i et bestemt Niveau en Række af 1,5 til $2 \mathrm{~m}$ høje Gryder fyldte med Sand og indbyrdes adskilte ved smalle Kamme af Grus. De enkelte Sten i Kammene er tydeligt rejst paa Højkant. Dette er et Forhold af stor Interesse; i den arktiske Brodelboden er noget saadant netop karakteristisk for Stenene i Stenringene. Af stor Interesse er endvidere Becksmanns (1931) Beskrivelser af »Brodelboden« fra Røde Klev paa Sild. Her findes to Horisonter med tydelig Brodelboden. Den øverste Horisont er udviklet i Hedesandet og bestaar af kun smaa, men efter hans Fotografier at dømme, smukt udviklede Gryder. Den nederste og største Brodelhorisont, der findes nede i Moræneleret, er imidlertid den mest interessante. Her finder man nemlig tre Generationer af Gryder inden i hinanden. BecksMANN mener ikke med Sikkerhed at kunne udtale sig om Aarsagen til dette Fænomen, men nævner to Muligheder; enten en Andring til et varmere Klima, eller en Sænkning af Sommerens Middeltemperatur i den Tid, Brodelhorisonten er blevet dannet. I begge Tilfælde skulde der efter hans Mening kunne dannes mindre Gryder inden i de allerede dannede Gryder. Den nedre Brodelhorisont er dækket af Flydejord.

Foruden disse Afhandlinger har Wolffs (1930) og BAHrs (1932) Beskrivelser af saadan Strukturmark fra Sønderjylland og Holsten særlig Interesse for danske Forhold. Begge Forfattere har ogsaa her fundet "Reder« af fint Sand, adskilt ved »Mure« af andet Materiale. BAHR skelner saaledes mellem "Redernes Nedsynkningsmasser», bestaaende af rødligt, forvitret Materiale og "Stigmasserne« i Kammene, der bestaar af det samme Materiale som Lagene under Gryderne, og som derfor gør Indtryk af at være presset op imellem Gryderne. Paa Grund af dette Udseende af Brodelhorisonterne forkaster han GrIPPS Brodelhypotese som Forklaring af disse Fænomener. Det vertikalt rettede Pres, der i Følge hans Opfattelse maa være Aarsag til disse Oppresninger skulde da fremkomme, naar det optøede Lag over Tjælen frøs til fra Overfladen og nedefter. Han foreslaar derfor Benyttelsen af den af WoLfF (1930) indførte Betegnelse »Würgeboden" for saadanne Fænomener. Et andet interessant Eksempel paa »Brodelboden« er beskrevet fra Villingen i Baden af Gellert (1933). Han har iagttaget ca. $1 \mathrm{~m}$ høje "Brodeltöpfe« i diluviale Aflejringer over Plattenkalk. Den vigtigste Iagttagelse, GELLERT har gjort, er, at Teksturerne er udtrukken i Retning af Terrænets Fald.

I alle de ovennævnte Tilfælde har det drejet sig om Forstyrrelser af relativ betydelige Dimensioner, naar man tager Hensyn til Normalstørrelser af saadanne Fænomener, men foruden saadanne store Brodelhorisonter finder man ogsaa hyppigt Horisonter opbygget af langt mindre Gryder. Herhen maa henføres de Horisonter, som Bennhold (1929) beskriver fra Wernsdorff i Nærheden af Berlin, og Pfunts (1932) fra Glindow bei Werder i Mecklenburg. I begge Tilfælde maa Brodelhorison- 
terne være udviklet samtidig med Materialets Aflejring, eller i hvert Fald under en kun kortvarig Afbrydelse af Sedimentationen. Ved Werndorff synes Horisonten at være veludviklet med tydelige Gryder. Dette er imidlertid aabenbart ikke Tilfældet ved Glindow. Ifølge Pfunls Beskrivelse bestaar Horisonten her af ejendommelige, forgrenede Sandpølser der ligger indlejret i Mergelsand. PFuHL forklarer disse Pølser som et Eksempel paa Stenstriber. Det maa imidlertid indtil videre henstaa i det uvisse, om Stenstriber i Snit kan opvise saa ejendommelige Teksturer. Mens Bennhold ubetinget slutter sig til Gripps Brodelhypotese, mener PfunL, at Forskelle i Vægtfylde mellem de forskellige Lag kan have spillet en Rolle ved Frembringelsen af saadanne Teksturer. Nogle Iagttagelser af A. DüCKER (1933) har meget stor Interesse for Beviset for disse Fænomeners Identitet med de arktiske Brodelfænomener. Ved Undersøgelsen af en Stenslette Syd for Elmshorn, der dannede en temmelig flad Skaal opfyldt af Flyvesand, iagttog han paa Skaalens laveste Sted en smuk udviklet Brodelboden umiddelbart under Stensletten. Ved horisontal Afgravning af denne Stenslette viste det sig, at Stenene her var ordnet i regelmæssige Ringe, følgende »Oppresningerne« i Brodelhorisonten. Ved yderligere Afgravning iagttoges det, at "Oppresningerne" dannede et temmelig regelmæssigt Netværk, omgivende de lysere mere sandede Partier. Ved Afgravningen af Stensletten et andet Sted paavistes det, at Stenene her laa ordnet i regelmæssige Striber. I en Lergrav ved Biesendorf er der ogsaa iagttaget Teksturer, der tydes som Stenstriber (Wittmann 1936). Da der imidlertid ikke foreligger Fotografier, og Teksten paa dette Punkt er meget kortfattet, er det vanskeligt at danne sig nogen Begreb om Rigtigheden af denne Antagelse. Foruden disse ovenfor omtalte Forekomster angives endnu et Par, nemlig fra Sassnitz paa Rügen (Richter 1933) og fra Jasmund (Schultz 1931). Endvidere kender man Brodelboden fra Hannover (Beschoren 1931). Efter Fotografierne at dømme, er denne Brodelboden ikke saa typisk, som den i Winterhude og Ilse-Ost. Det samme maa siges om de Eksempler, der angives fra Holland. (Edelmann, Florschütz og Jeswiet 1936).

En Del ældre Beskrivelser af forstyrrede Lag er i den senere Tid blevet fortolket som Eksempler paa Brodelboden. Dette har blandt andet været Tilfældet med nogle Beretninger af CREDner (1880) og WAHNSChaffe (1882) (Ref. Pfuhl 1932). Credner beskriver Forstyrrelser, som han har iagttaget $\mathrm{i}$ det nordøstlige Sachsen. Her fandt han oligocænt Ler og Diluvialler presset op i Morænen i »skyformige Masser« eller uregelmæssige Klumper. I visse Tilfælde kan Beretningen om saadanne Fænomener lede Tanken hen paa Brodelboden. Beskrivelsen af Fænomenerne er imidlertid ogsaa her saa kortfattet, at man ikke med Sikkerhed tør sige, at de iagttagne Forstyrrelser overhovedet har haft noget at gøre med Flydejord. Det samme gælder Wahnschaffes Undersøgelser, men 
han giver dog Tegninger af Fænomenerne. Efter disse maa man imidlertid regne med, at WAHNSCHAFFES egen Forklaring er den rigtige, nemlig at disse Opstuvninger er opstaaet ved Istryk.

Et Profil fra Klinge ved Cottbus, der er blevet beskrevet af ScHroeder \& SToller (1905), er ogsaa blevet fortolket som Brodelboden (EdELMan, Florschütz \& Jeswiet 1936; Gripp 1927). Een af Figurerne i Afhandlingen, Fig. 2, viser en enkelt Oppresning af Tørv i det overliggende Sand. Forstyrrelserne i Profilet kan muligvis skyldes Solifluktion, men ogsaa i dette Tilfælde gælder det, at hverken Tegning eller Tekst giver noget sikkert Holdepunkt for en saadan Antagelse. De Stenringe, der er iagttaget af GELLERT \& SchüLLER (1929) i Riesengebirge stammer sikkert ikke fra Diluvialtiden. Hertil kan man endnu føje en Række Eksempler paa Fænomener, som ganske vist viser mange Træk, der er karakteristiske for Brodelfænomenerne, men som det paa Grundlag af Beskrivelserne er meget vanskeligt at danne sig noget Begreb om. En Del af disse er refereret af Kessuer (1925). Det drejer sig blandt andet om Forekomsten af flammeformede Oppresninger i Flydejord. Efter Tegningerne (RATHJEns 1920) er det ikke udelukket, at saadanne Oppresninger i Virkeligheden danner en Brodelhorisont. Det er dog ikke ganske afgjort; saadanne flammeformige Figurer kan ogsaa findes i Flydejord, hvor der antagelig ikke er sket nogen Brodelbevægelse. Af stor Interesse er de ca. $2 \mathrm{~m}$ dybe "geologiske Orgler", som BRÄUḦ̈USER har beskrevet fra Endersbach. Hans Beskrivelse og Tegninger tyder afgjort paa, at der her er fundet en ualmindelig smukt udviklet Brodelboden med meget store Gryder. Han bemærker saaledes, at de enkelte Sten i Stenkammene, der omgiver de cylinderformede Gryder, ligger parallelt med Grydernes Sider. BRÄUнÄUSER forklarer disse Gryder som Jættegryder; KessLen mener imidlertid, at Gryderne er dannet ved Nedsynkningen af de store Blokke, som man hyppigt finder paa Grydernes Bund.

I Frankrig har man længe haft Opmærksomheden henvendt paa den Indflydelse, Jordflydningen maa have haft paa Landskabsformerne. Man har tidligere bemærket, at man hyppigt finder paafaldende mange lodret stillede Sten i den øverste Del af Gruslejringer o. lign., hvilket man har antaget skyldes Solifluktion (Віgот 1928, 1930, 1931, 1935). I et enkelt Tilfælde (Bigot 1930) er der publiceret et Fotografi af en saadan Aflejring med lodret stillede Sten. Man ser tydeligt paa Billedet tre meget smukke Gryder, fyldt med stenfattigt Materiale og adskilte ved Kamme af Grus, hvori de fleste Sten er rejst paa Højkant. Et andet interessant Tilfælde er beskrevet fra Brignogan i Dep. Finistère (Yves Milon \& L. Berthois, 1930). Ude langs Stranden, hvor Havet havde bortskyllet de øverste Lag, iagttoges et ejendommeligt Netværk, hvis Masker var ca. $1 \mathrm{~m}$ i Diameter. De enkelte Polygoner var adskilte fra 
hverandre af lerede, $2-4 \mathrm{~cm}$ brede Kranse af grovere Materiale. Forfatterne fremhæver dette Fænomens slaaende Lighed med den arktiske Strukturmark.

Fra Danmark foreligger der kun yderst faa Iagttagelser over Brodelfænomenerne fra Istiden. Af størst Interesse er Jessens (1922) Beskrivelser fra Esbjærg-Klinten og Teglværksgravene tæt her ved. Alene ud fra den fortræffelige Beskrivelse og de udmærkede Fotografier kan man med Sikkerhed udtale, at de forstyrrede Lag, som Jessen paa det Tidspunkt mente skyldtes Istryk, i Virkeligheden er en smuk Brodelhorisont. Som det vil ses af de følgende Sider, har Undersøgelserne da ogsaa vist, at vi her finder een af de smukkeste og tydeligste Brodelhorisonter, der findes her i Landet.

Foruden Beretningen om denne Horisont ved Esbjærg tyder Beskrivelsen af Mosen i Brørup Mergelselskabs Grav i høj Grad paa, at man her har staaet over for en Brodelhorisont. Om Forholdene her i Sommeren 1913 skriver V. Mптнеrs følgende: ». . . Det øverste Lag af Ferskvandsaflejringen var brun Gytje. Det havde en Mægtighed af indtil $1 \mathrm{~m}$. Øverst var det pletvis noget sandet og indeholdt hist og her indpressede Sten. Sandpartierne foroven optraadte enten poseformede eller som Striber, og Gytjelagets Overkant var ret uregelmæssig, rimeligvis som Følge af det Pres, som Laget har været underkastet ved det overliggende, stenede Sandlags Aflejring. En ganske tilsvarende uregelmæssig Grænse finder man mellem Sandlaget og Leret udenfor Ferskvandslagets Omraade.De nederste Dele af Laget bestaar ofte af næsten rent Sand, men kan ogsaa pletvis være stærkt stenet. I de mest finkornede Partier er der hist og her nogen Lagdeling at se; hvor Laget derimod er stærkt stenet er der ingen Sortering at spore, og Stenene sidder ganske uregelbundne baade paa Højkant og i anden Stilling«. Mrthers mener, at dette Dæklag skal opfattes som net stenet og sandet, pletvis vandsorteret, Morænedække, afsat tæt ved Ydergrænsen for den Nedisning, som fulgte efter Dannelsen af de interglaciale Moser i Brørup-Egnen«. Denne Opfattelse sluttede V. Nordmann sig til, mens A. Jessen nærede Betænkeligheder ved at gaa ind paa denne Tankegang. (A. Jessen, V. Madsen, V. MuLThers \& V. Nordmann 1918). Til Slut skal omtales nogle Fotografier, som velvilligst er overladt mig af A. Rosenkrantz. To af disse stammer fra Stenlille Aas og viser nogle ejendommeligt krøllede Lag, der findes i et Lerlag i Aasen. De er tidligere iagttaget og beskrevet af S. A. ANDERSEN (1931). Der ses imidlertid ingen tydelige Gryder i disse Lag, og Forstyrrelserne ligner ikke de almindelige Brodelstrukturer. TH. SøRENSEN har imidlertid mundtlig meddelt mig, at han anser saadanne Teksturer for at være dannet ved en eller anden Form for Solifluktion. Et tredie Billede viser saakaldte »kontortede Lag« fra Udgravningerne til Københavns Frihavn. Man kan ikke nægte, at disse Forstyrrelser viser en stor 
Lighed med Brodelteksturerne fra Vestjylland. Desværre er det ikke længere muligt at undersøge Lokaliteten; det er nemlig meget paafaldende, hvis disse Fænomener, som hidtil fortrinsvis er fundet i Vestjylland uden for Grænsen for den sidste Nedisning ogsaa skulde findes i Jordbunden ved København.

\section{Beskrivelse af de vigtigste Lokaliteter.}

\section{Klinten ved Esbjærg.}

Som omtalt i det foregaaende Afsnit er Forekomsten af Brodelboden i Teglværksgravene og Klinten ved Esbjærg tidligere omtalt ret udførligt af A. JESSEN, der dog ikke paa det Tidspunkt erkendte disse forstyrrede Lag som Brodelboden. Klinten er nu meget nedskreden, og der findes for Øjeblikket kun tydelige Profiler i den Del af den, der ligger Sydøst for den store Teglværksgrav umiddelbart Øst for Byen. Den vestlige ca. $20 \mathrm{~m}$ lange Del af Klinten danner to Næser, der springer $3-4 \mathrm{~m}$ frem mod Sydvest. Det følgende ca. $45 \mathrm{~m}$ lange Klintparti mod Øst har et næsten retlinet, kun svagt bugtet Forløb. Klinten er ca. $3 \mathrm{~m}$ høj mod Vest, men bliver ca. ${ }^{1 / 4} \mathrm{~m}$ lavere i den østlige Ende af Profilet. Den derpaa følgende Del af Klinten er ganske tilskreden, og paa dette Stykke aftager dens Højde stærkt. Klinten fortsættes til sidst af en lav, kun knæhøj Skrænt til Gammelby Teglværks Udskibningskaj.

Som det vil ses af Tegningen (se Tvl.), danner Yoldia-Leret Klintens nederste Lag i Profilets nordvestlige Ende. Dets Overflade hælder dog temmelig stærkt mod Sydøst og forsvinder hurtigt under Havets Niveau. Sydøst for Næse II ser man ikke mere Leret stikke frem i Klintfoden. Umiddelbart over Leret ligger der to ca. $20 \mathrm{~cm}$ tykke Lag af Fingrus, adskilt af et Lag af Finsand af vekslende Mægtighed. Det nederste Lag Fingrus, der hviler direkte paa Yoldia-Leret, synes at følge dette i Dybet, mens Finsandslaget svulmer op mod Sydøst. I dette Finsand og i det øverste Lag Fingrus findes Brodelhorisonten udviklet. Den øverste Del af Klinten bestaar af et 0,5-1,0 m mægtigt Lag af stenet Sand, som for en stor Del er sammenkittet til en fast Rødal. Et ca. $20 \mathrm{~cm}$ tykt Pløjelag danner et øverste Dække over hele Klinten. Som man vil se af Tegningen, danner Blegsandet flere ejendommelige Nedposninger, særlig i den nordvestlige Del af Profilet. Nogle af disse skyldes muligvis Virkningen af dybtgaaende Planterødder (Ramann 1886). Dette er rimeligvis Tilfældet med de tre Nedposninger i Næse I paa begge Sider af Frostspalten, (se Trl.) og med Blegsandstappene i Gryderne Nr. 39 og Nr. 40. I den sidstnævnte ser man endog et sammenfiltret Rodnet, der 
følger Tappen. Lignende Tappe, til Tider ogsaa indeholdende Rodnet, er forøvrigt iagttaget flere Steder i Klinten, men de er i Almindelighed af ubetydelig Størrelse, hvorfor de ikke er medtaget paa Tegningen. Tappenes Indhold af ret friske Planterødder er imidlertid ikke noget afgørende Bevis for, at de er dannet af disse Rodnet; thi Planterødderne vil altid søge at følge saadanne Tappe, hvis de i Forvejen er dannede. Man ser f. Eks. hyppigt Rodnet følgende Frostspalterne. Disse Blegsandstappe er nemlig Planterøddernes eneste Mulighed for at trænge ned igennem den ret faste Al. Flere Steder ligger Stenene næsten alle parallelt med Tappenes Sider. Ligeledes gør Gryde Nr. 40 tydeligt Indtryk af at være delvis ødelagt af den Tap, der gaar ned i den. Saafremt disse Tappe er dannet af Planterødder, maa det have været meget kraftige Rødder, almindelige Urterødder formaar nemlig kun at ødelægge Sandets fine Lejring, men i Almindelighed ikke at ændre Stenenes Beliggenhed i Sandet. De to store uregelmæssige Partier af Blegsand, der ses mellem Næse I og Næse II er det imidlertid vanskeligt at finde nogen Forklaring paa. Man kan vanskeligt tænke sig, at saadanne Nedposninger kan være dannet af Trærødder.

Brodelhorisonten er næsten overalt ualmindeligt smukt udviklet med meget tydelige Gryder og er et af de smukkeste Eksempler paa Levninger af arktiske Froststrukturer, jeg har fundet her i Landet. Den er daarligst udviklet i den nordvestlige Del af det nuværende Profil. I Næse I findes dog Spor af nogle Gryder.

Gryderne Nr. 1, 2, 3, 4 og 5. Disse Gryder er ret utydelige. De er alle nedsænkede i det øverste af de to Gruslag, der ses over Yoldialeret, og som lader sig forfølge gennem et langt Stykke af Klinten. Deres Bredde er ret anselig; Nr. 1 er $75 \mathrm{~cm}$ bred; Nr. 2 og 3 er tilsammen 85 cm brede og udgør sandsynligvis tilsammen en enkelt Gryde; Nr. 4 er $135 \mathrm{~cm}$ bred; Nr. 5 er $140 \mathrm{~cm}$ bred. I den følgende Del af Klinten ses ikke noget Tegn paa Brodelbevægelse. Partiet fra Nr. 5's østlige Kam til Nr. 6's vestlige Kam kan dog muligvis regnes som en Gryde. I det hele taget er alle disse Gryder meget utypiske i deres Udseende. Den store Breddeforskel skyldes muligvis, at de, som det senere vil blive nærmere omtalt, er trugformede og skaaret i et skævt Snit af Profilvæggen paa dette Sted.

I Næse II's vestlige Væg, der stryger meget nær N-S, ser man en tydelig Stenkam, truffet i Længdesnit (Fig. 1). Den øverste, knap een Meter høje Del af Profilet viser her en forvirret Pakning af større og mindre Sten. Her nedenunder ser man skraalejret, gulligt Sand. Skraalagene hælder en halv Snes Grader mod Nord. I en Del af Profilet ser man umiddelbart under Stenkammen knæbøjede Lag (Fig. 2), der viser, at Kammen har bevæget sig i nordlig Retning i Forhold til det nedre Sand. Oven paa Klinten ser man imidlertid ikke noget Fald af Betydning i den Retning 


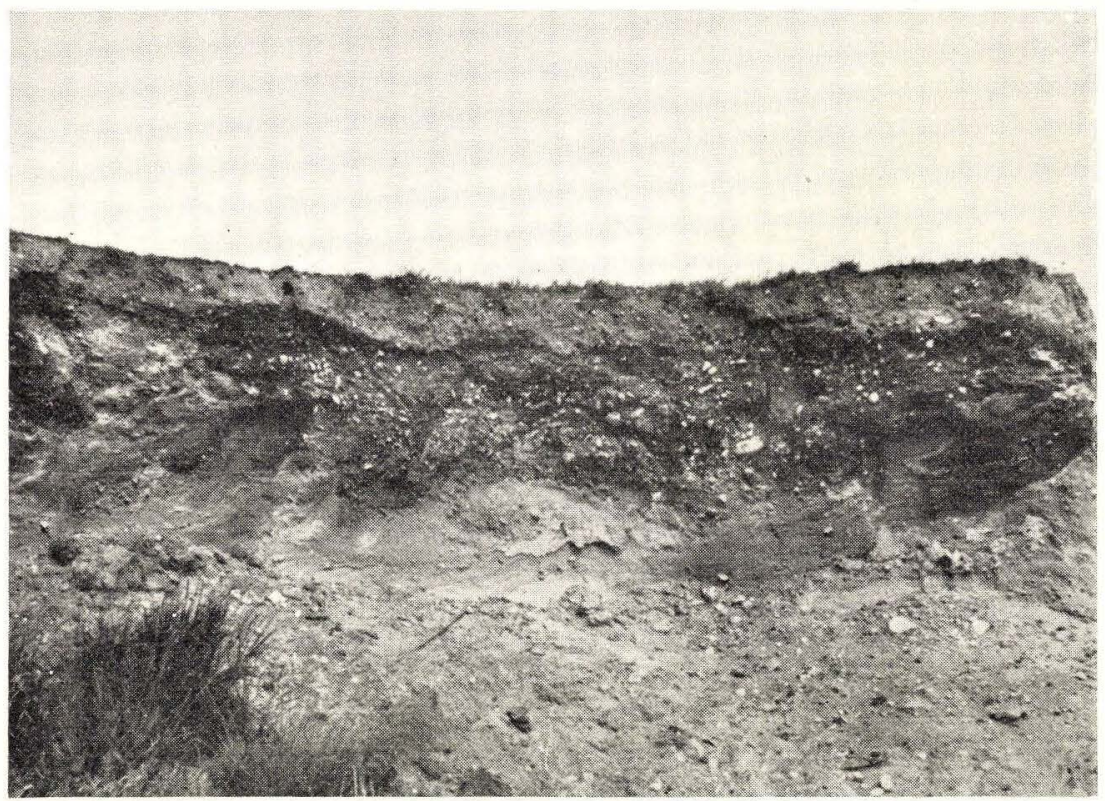

Fig. 1. Næse II's vestlige Væg. Den utypiske Gryde mellem Gryde Nr. 5 og Gryde Nr. 6. Stenkam i Længdesnit.

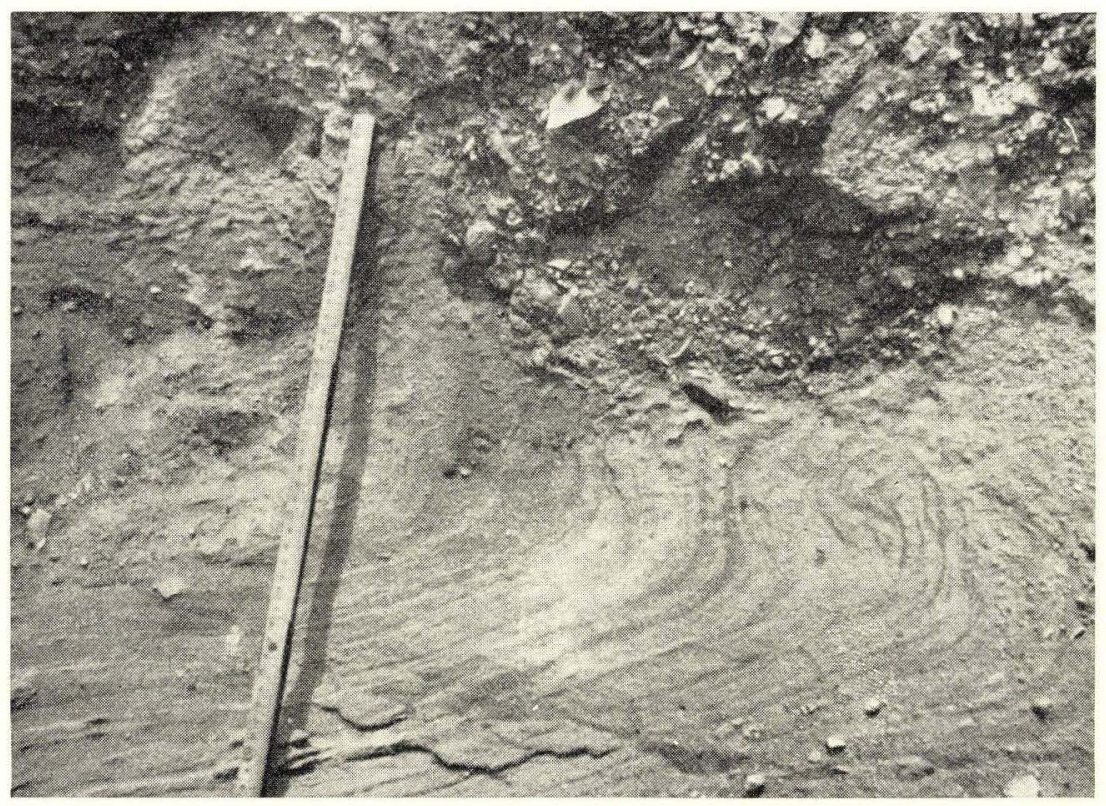

Fig. 2. Parti af Næse II's vestlige Væg. Lag knæbøjet ved Stenkammens Bevægelse i nordlig Retning. 
i Nutiden. Det viste sig at være meget vanskeligt at grave ind i Væggen paa dette Sted, fordi Materialet er saa stenet og yderligere er blevet kittet fast sammen af Alen. Det lykkedes imidlertid et enkelt Sted at foretage en mindre Udgravning og herved viste det sig, at det stenede Parti virkelig er en Kam, der løber parallelt med Væggen, hvad man ogsaa efter Forholdene paa Næsens anden Side maatte forvente. Bag den smalle Kam saas svagt stenet, gulligt Sand.

I Næsens sydeksponerede Væg, der skærer den vesteksponerede i en omtrent ret Vinkel, ser man tre ret tydelige Gryder.

Gryderne Nr.6, 7 og 8 er de vestligste Gryder, der fremtræder nogenlunde tydeligt. Kammene, der adskiller dem, er dog temmelig lave - ikke mer end ca. $40 \mathrm{~cm}$ høje. Nr. 6 er ca. $60 \mathrm{~cm}$ bred; Nr. 7 er $90 \mathrm{~cm}$ bred; Nr. 8 er $45 \mathrm{~cm}$ bred.

Gryderne Nr. 9, 10, 11, 12 og 13 er derimod meget utydelige, og Tegningen (Tvl. 1) er paa dette Sted temmelig skematiseret. Kammene mellem Gryderne er utydelige og kan kun findes, naar man forsøger at forbinde de forskellige løsrevne Partier af Grus med hinanden.

Den herefter følgende ca. $20 \mathrm{~m}$ lange Væg er saa nedskreden, at der ikke er nogen tydelige Gryder at se. I de sidste $5 \mathrm{~m}$ af Væggen ser man dog fire meget utydelige Gryder.

Gryderne Nr. 14, 15, 16 og 17 er alle nedarbejdede i Finsandet, hvorfra de adskiller sig ved en noget mere gullig Farvetone.

Gryderne Nr. 18 og 19 er to ret tydelige Gryder. De er begge ea. $80 \mathrm{~cm}$ brede og naar ca. $100 \mathrm{~cm}$ ned under Blegsandets Underkant. De er adskilt fra hinanden ved en ret utydelig ca. $60 \mathrm{~cm}$ høj og $15 \mathrm{~cm}$ bred Kam af Melsand.

Gryde Nr. 20. Mellem Nr. 19 og Nr. 21 ser man en lille Klat af sort ret groft Sand. Den er ca. $45 \mathrm{~cm}$ i Diameter og af uregelmæssig cirkulær Form. Dens Underkant ligger ca. $10 \mathrm{~cm}$ højere end de omgivende Gryders. Som Følge af Sammenkitningen af Sandkornene var det vanskeligt at grave i den, men det lykkedes alligevel at skrælle saa meget af Klintfladen af, at man kunde se, at den bliver større og dybere indadtil og i det hele taget indefter antager en mere normal Grydeform. Nr. 20 maa saaledes opfattes som et Trug, hvis Længdeakse stryger i en nord-sydlig Retning, og som her er snittet af Profilvæggen i sin yderste, sydlige Spids.

Derefter følger en ca. $10 \mathrm{~m}$ lang Væg, hvori man ser $8-9$ tydelige Gryder. De har alle en meget typisk og udpræget Form og fremtræder skarpt adskilte ved $5-10 \mathrm{~cm}$ brede og indtil $75 \mathrm{~cm}$ høje Kamme af gulligt Sand, der næsten er stenfrit. Et Lag af graabrunt, visse Steder næsten sort, og i Reglen temmeligt groft Sand, der indeholder en Mængde Smaasten paa Størrelse med Hasselnødder, beklæder Grydernes Inderflader. Dette Lag fremtræder særlig tydeligt i de seks vestlige Gryder, 
hvor det kan danne et indtil 5 cm tykt Lag i Grydernes Bund. De Sten, der har en tydelig Længdeakse, ligger alle, næsten uden Undtagelse, konformt med Grydernes Inderflade. De staar følgelig lodret langs Kammene og ligger paa Fladen i Grydernes Bund. Alle Gryderne er fyldt med rødgult Sand med enkelte spredte Sten. De er nedsænkede i næsten rent hvidt, gulspættet Melsand. Den vestligste af disse Gryder er betegnet som

Gryde Nr. 21. Den er $55 \mathrm{~cm}$ bred, og naar ca. $1 \mathrm{~m}$ ned under Blegsandets Undergrænse. I Grydens Indre ser man et Par hønseægstore Flintesten.

Gryderne Nr. 22 og 23 er to Tvillinggryder med fælles Underrand. De er adskilte fra hinanden ved en opadvendt Kile af det sorte Sand. Nr. 22 er $50 \mathrm{~cm}$ bred; Nr. 23 er $40 \mathrm{~cm}$ bred. Nr 22 indeholder i Midten et Parti af stærkt stenet Sand. Nr. 23's østlige Del er ogsaa temmelig stenet. Kammen, der adskiller de to Gryder, er ca. $30 \mathrm{~cm} \mathrm{høj.}$

Gryde Nr. 24 er en lille Gryde, der knap nok naar ned i samme Niveau som de omgivende større Gryder. (Fig. 3). Den er kun ca. $35 \mathrm{~cm}$ bred, og utydelig adskilt fra Nr. 23.

Gryde Nr. 25 er ogsaa kun en lille Gryde (Fig. 3); den har omtrent de samme Dimensioner som Nr. 24. Den er imidlertid meget tydeligt adskilt fra denne af en $18 \mathrm{~cm}$ bred og $33 \mathrm{~cm}$ høj Kam af rektangulært Tværsnit. Indeni denne Gryde ser man en mindre, sekundær Gryde, der er ret tydeligt markeret af et Stenlag, bestaaende af en enkelt Række Sten paa Størrelse med Hasselnødder. Ved Gravning ind i denne Gryde viste det sig, at begge de begrænsende Kamme fjerner sig fra hinanden indefter, idet de i horisontalt Snit viser sig som to Grene af en Parabel, hvis Spids er bortskaaret af Profilvæggen. Ligeledes ses det, at Grydens Bund sænker sig indefter, saaledes at den utvivlsomt et Stykke inde vil naa ned til samme Dybde som den noget dybere Nr. 26. Ved Udgravningen forsvandt Nr. 24 omtrent helt, saaledes at det sikkert vil vise sig, at Nr. 23 og Nr. 25 grænser op til hinanden et Stykke inde i Væggen. Det Snit igennem Brodelhorisonten, vi ser i Klinten, har følgelig truffet Sydsydvestenden af Nr. 25 og Nordnordøstenden af $\mathrm{Nr}$ 24, mens Nr. 21 og i hvert Fald ganske givet Nr. 26 er blevet snittet midt over. Den ret betydelige Bredde af den rektangulære Kam, der adskiller disse to Gryder, er kun tilsyneladende og skyldes det skæve Snit. I vinkelret Snit er den kun ca. $5 \mathrm{~cm}$ bred. Hvis man sammenligner Fotografiet (Fig. 3) med Tegningen af Klinten (se Tvl.), vil man bemærke, at Tegningen viser Forholdene som beskrevet ovenstaaende, mens Fotografiet viser Nr. 24 som en tydelig Gryde. Dette skyldes, at Opmaalingen af Klinten er foretaget i Sommeren 1938, mens Fotografiet er taget i Foraaret 1937. I Løbet af 1937/1938 har Havet nemlig skaaret sig noget mere ind i Væggen paa dette Sted.

Danmarks Geologiske Undersøgelse. II. R. Nr. 74. 
Gryde Nr. 26 er en forholdsvis stor Gryde (Fig 3 og 4), den naar ca. $20 \mathrm{~cm}$ dybere ned end de øvrige, der omgiver den; den er $105 \mathrm{~cm}$ bred. Fra Nr. 25 er den tydeligt adskilt ved en $5 \mathrm{~cm}$ bred og ca. $100 \mathrm{~cm}$ høj Kam af Finsand, der opadtil bliver temmelig stenet. Kammen viser i sin øverste Del en ret stærk Bøjning mod Øst. Grydens Inderflade er betydelig mere stenet end Inderfladerne af de ovenfor omtalte Gryder. I Grydens øverste Halvdel ses talrige nøddestore Sten, der næsten alle er rejst paa Højkant. Gryden er særlig interessant, fordi den er delt i to mindre, sekundære Gryder, hvilket man tydeligt ser af Lejringen i Grydens Sand. (Fig. 4).

Gryderne Nr. 27, 28 og 29 er nedsænkede i. Finsandet, de $\in \mathrm{r}$ tydelig adskilte fra dette $\mathrm{og}$ fra hverandre af et indtil $20 \mathrm{~cm}$ svært Stenlag. Selve Grydernes Indhold bestaar af fint Sand, der opefter bliver ret stærkt stenet. Nr. 27 er kun skilt fra Nr. 28 ved en opadvendt Kile af Grus, op i hvilken Melsandet ogsaa fortsætter sig et lille Stykke. Nr. 29 er omtrent fuldstændigt dækket af nedskredne Masser. Den er opadtil stærkt stenet.

Det følgende Stykke af Væggen er ret stærkt nedskredent, men ved en lille Udgravning lykkedes det at afdække syv Gryder.

Gryde Nr. 30 ligger i et noget højere Niveau end Nr. 29, som den synes at overdække med sin vestligste Rand.

Gryde Nr. 31 er ea. $70 \mathrm{~cm}$ bred og naar ned i samme Niveau som Nr. 29. Den er adskilt fra Nr. 30 ved en ret utydelig Kam af Grus.

Gryde Nr. 32 er kun adskilt fra Nr. 31 ved en opadvendt, ca. $20 \mathrm{~cm}$ høj og ved Grunden ca. $30 \mathrm{~cm}$ bred Kile af Grus. Baade Nr. 31 og Nr. 32 viser sig skarpt adskilt fra Melsandet ved et ca. $1 \mathrm{~cm}$ tykt Lag af groft Grus. Gryderne er begge fyldt med gulligt Sand, der opadtil bliver temmelig stenet.

Gryde Nr. 33 er tydelig adskilt fra Nr. 32 ved en ca. $55 \mathrm{~cm}$ høj og ved Grunden ca. $40 \mathrm{~cm}$ bred Kile af Melsand, beklædt med et ca. $1 \mathrm{~cm}$ tykt Lag af groft sort Sand, der indeholder enkelte Sten. Selve Gryden er fyldt med okkergult Sand, der i den østlige Del af Gryden antager en noget mere graalig Farvetone. Sandet indeholder enkelte smaa Sten paa Størrelse med Hasselnødder. Gryden er ca. $50 \mathrm{~cm}$ bred.

Gryde Nr. 34 er tydelig adskilt fra Nr. 33 ved en $25 \mathrm{~cm}$ høj og ca. $5 \mathrm{~cm}$ bred Kam af graaligt Finsand, der er beklædt med et tyndt Lag af sort Sand. Gryden er ikke mere end $35 \mathrm{~cm}$ bred og er fyldt med graabrunt Sand.

Gryde Nr. 35 er betydelig større end den foregaaende. Den er ca. $75 \mathrm{~cm}$ bred og ligesom Nr: 34 fyldt med graaligt Sand, der indeholder enkelte storre Sten. Den er adskilt fra Nr. 34 ved en $25 \mathrm{~cm}$ høj tilspidset, ved Grunden ca. $15 \mathrm{~cm}$ bred Kam af graaliggult Finsand. Den er beklædt 
23

24

25

26

27

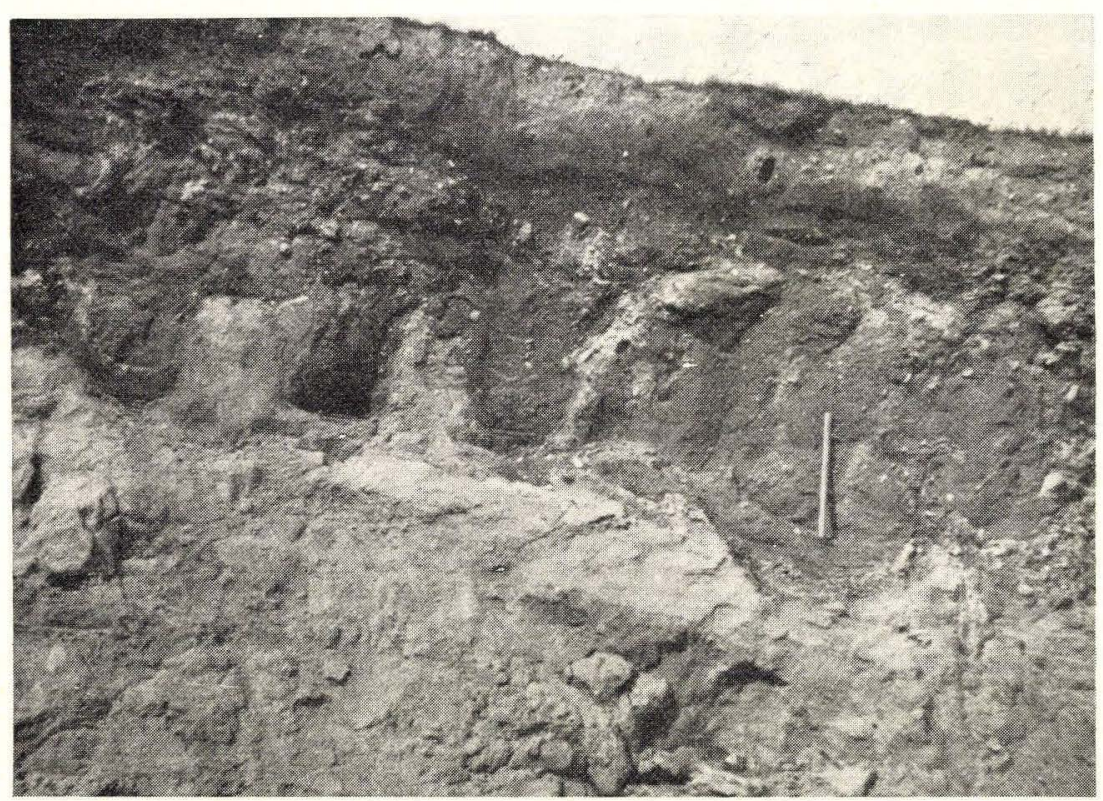

Fig. 3. Klinten Øst for Esbjærg. Gryderne Nr. 23, 24, 25, 26 og 27.

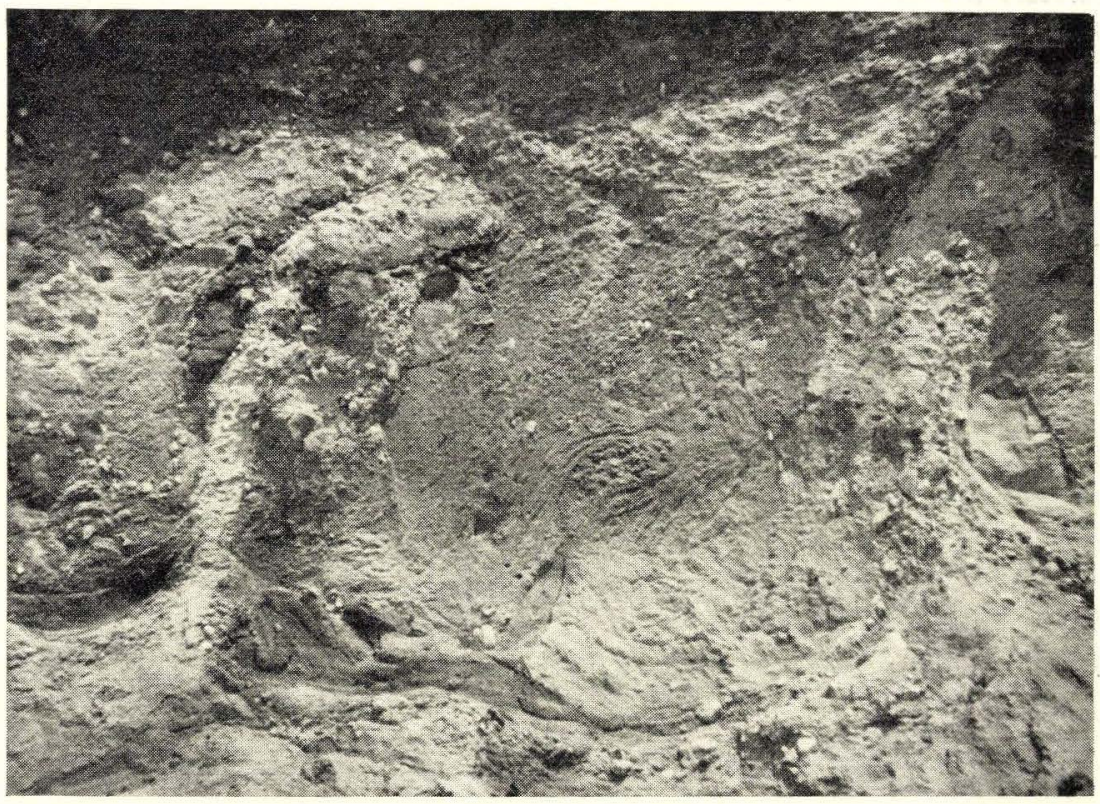

Fig. 4. Klinten Øst for Esbjærg. Gryde Nr. 26. 
med et ca. $1 \mathrm{~cm}$ tykt Lag af grovere sort Sand, der indeholder enkelte Sten paa Størrelse med Hasselnødder. Den er kun adskilt fra

Gryde Nr. 36 ved en stenet, ved Grunden melsandet, ca. $5 \mathrm{~cm}$ bred, men opefter ret utydelig Kam af Sten paa Størrelse med Hasselnødder. Gryden er ca. $55 \mathrm{~cm}$ bred.

Herefter følger en ca. $2 \mathrm{~m}$ bred Revle af Grus, bestaaende af Sten op til Knytnævestørrelse. Dette Grus hviler direkte paa Finsandet, som det grænser op til i samme Niveau som Brodelgryderne. Hist og her kan man skelne Teksturer, der tyder paa, at der her findes smaa Gryder, men nogen tydelige Gryder lader sig ikke udskille. Efter denne Stenrevle følger en ca. $12 \mathrm{~m}$ lang Væg, hvori der ses elleve for største Delen meget smukke Gryder.

Gryderne Nr. 37 og 38 er begge nedsænkede i et ca. $30 \mathrm{~cm}$ mægtigt Gruslag (Fig. 5). De er ca. $50 \mathrm{~cm}$ brede, naar ca. $100 \mathrm{~cm}$ ned under Blegsandets Undergrænse og er adskilte fra hinanden ved en ca. $30 \mathrm{~cm}$ høj Kam af Grus, der nederst har Form som en ca. $15 \mathrm{~cm}$ høj opadvendt Kile, men som opefter udvider sig til et paraplyformet Hovede, der er ca. $15 \mathrm{~cm}$ bredt og $5 \mathrm{~cm}$ højt. Hovedet er forbundet med Kilen ved et ca. $10 \mathrm{~cm}$ højt Skaft, der kun er et Par cm bredt og som tegner sig meget utydeligt. Ved at grave ind i Gryde Nr. 38 viste det sig, at man fik afdækket den sydlige Ende af en baadformet Nedsænkning, der stryger omtrent NNO-SSV. Ligesom det er Tilfældet med Nr. 25, fordyber Gryden sig indadtil, og Kammene viger bort fra hinanden, indefter i Væggen. Gravningerne i Nr. 37 gav et ganske lignende Resultat.

Gryde Nr. 39 er meget bred; ca. $120 \mathrm{~cm}$, og den naar ned i samme Niveau som de to foregaaende (Fig. 5). Den er adskilt fra Nr. 38 ved en $30 \mathrm{~cm}$ bred og $25 \mathrm{~cm}$ høj rektangulær Grusmasse, der i det østlige Hjørne løber ud i en $35 \mathrm{~cm}$ lang, omtren't lodret Kam. Gryden blev ikke nærmere undersøgt, da det viste sig meget vanskeligt at grave i den, paa Grund af den store Mængde Sten, den indeholder, og Sandets stærke Sammenkitning til en fast Rødal. I den østlige Del af Gryden ser man en tapformet Nedposning fra Blegsandet; (se Tvl.).

Gryde Nr. 40. Som Gryde Nr. 40 er betegnet en nu næsten ødelagt Gryde, der er adskilt fra Nr. 39 ved en $1 \mathrm{~m}$ høj Kam af Grus, der hælder $60^{\circ} \bmod$ Vest. Kammen er $15 \mathrm{~cm}$ bred. Ned midt i Gryden, der er $110 \mathrm{~cm}$ bred, rager en $1 \mathrm{~m}$ lang, svagt bøjet, tapformet, $15 \mathrm{~cm}$ bred Nedposning fra det øverste Blegsand. Man ser i Tappen de ret friske Rester af et Rodnet, der har fulgt den ned igennem Alen. Stenene i denne Blegsandtap er tydelig ordnet parallelt med Tappens Ydervægge. Selve Grydens østlige Del er opfyldt af ret store Sten, og heri ser man en ca. $25 \mathrm{~cm}$ bred sekundær Gryde. Det er derfor muligt, at Gryde Nr. 40 oprindeligt har bestaaet af to mindre Gryder, 
hvis Grænsekam er ødelagt af den Trærod, der har dannet Blegsandsnedposningen.

Gryderne Nr. 41, 42 og 43. Disse Gryder er kun daarligt adskilte fra hverandre af to opadvendte, kileformede Kamme af Grus. Nr. 41 er $80 \mathrm{~cm}$ bred; Nr. 42 er kun $25 \mathrm{~cm}$ bred; Nr. 43 er ca. $45 \mathrm{~cm}$ bred paa det bredeste Sted. Kilen, der adskiller Nr. 41 fra Nr. 42 er $20 \mathrm{~cm}$ høj og $15 \mathrm{~cm}$ bred ved Grunden. Kilen, der adskiller Nr. 42 fra Nr. 43 er ca. $25 \mathrm{~cm}$ høj og lige saa bred; den fortsættes op til Blegsandet af en utydelig Stenstribe. Alle tre Gryder er fyldt af gult, kun svagt stenet Sand.

Gryde Nr. 44 er meget tydelig skilt fra Nr. 43 ved en Kam, der foroven udvider sig bredt hovedformet. Gryden er ca. $55 \mathrm{~cm}$ bred. Den er tydelig adskilt fra Nr. 45 ved en Kam, der naar helt op til Blegsandets Underkant. Kammen bestaar af Grus og er ca. $20 \mathrm{~cm}$ bred; den sender talrige Protuberanser ind i Grydens Indre (Fig. 6).

Gryde Nr. 45. Ogsaa ind i denne Gryde sender den ovenfor omtalte Kam Protuberanser (Fig. 6). Gryden er meget tydelig og temmelig bred. Dens Bredde ligger imellem $75 \mathrm{og} 85 \mathrm{~cm}$. Den er ligesom Nr. 44 fyldt med gulligt Sand, der nederst indeholder meget faa Sten, men som opadtil bliver ret stærkt stenet.

Gryde Nr. 46 er adskilt fra Nr. 45 ved en Kam, der er ca. $45 \mathrm{~cm}$ bred, og som bestaar af Grus, beklædt med sort Sand. Kammen naar helt op til Blegsandets Underkant (Fig. 6). Gryden er temmelig stor, ca. $1 \mathrm{~m}$ bred og fyldt med gult, svagt stenet Sand.

Gryde Nr. 47 er ligeledes stor; den har omtrent samme Bredde som den foregaaende. Den er adskilt fra Nr. 46 ved en Kam, der er ca. $25 \mathrm{~cm}$ bred, og som naar helt op til Klintens Overkant, idet den lader sig spore igennem Blegsandet. Kammen har en ret betydelig Afbøjning i østlig Retning (Fig. 6).

Gryde Nr. 48 er ikke mer end $50 \mathrm{~cm}$ bred. Klinten danner her en flad Næse (Næse III) ved den Kam, der adskiller denne Gryde fra Nr. 47. Kammen er ret bred, ca. $45 \mathrm{~cm}$ paa det bredeste Sted og bestaar af smaastenet Grus. Gryden synes ogsaa mod Øst at være velafgrænset ved en Kam af Fingrus.

I den herefter følgende Del af Klinten kan man hist og her finde Spor af Gryder. Klinten er imidlertid paa dette Stykke saa stærkt tilregnet og nedskreden, at der skal foretages ret betydelige Udgravningsarbejder for at bringe dem for Dagen.

2. Esbjærg Teglværk.

I den østlige Del af den store Teglværksgrav lige Øst for Byen graves der endnu en Del Ler til Teglværket. Ved Afrømningsarbejdet faar man ofte Lejlighed til at iagttage ejendommelige Brodelteksturer i Leret. Disse Teksturer er imidlertid i Almindelighed ret uregelmæssige, men en 
37

38

39

40

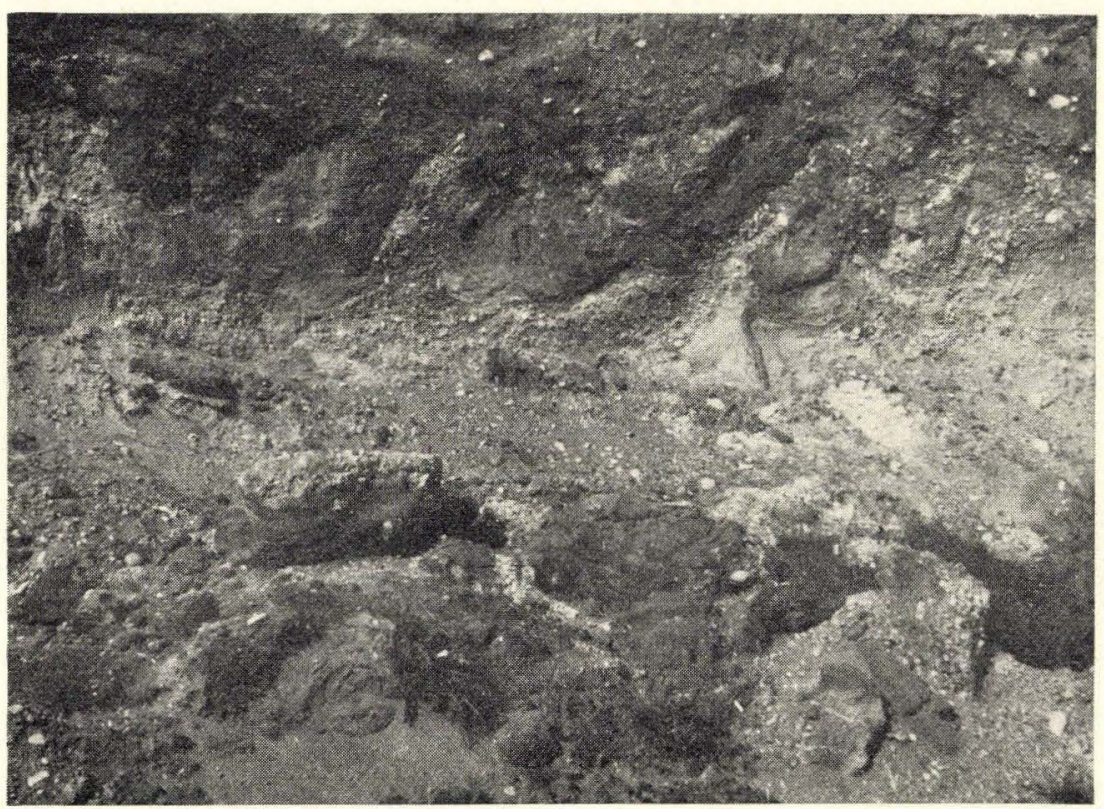

Fig. 5. Klinten Øst for Esbjærg. Gryderne Nr. 37, 38, 39 og 40.

45

46

47

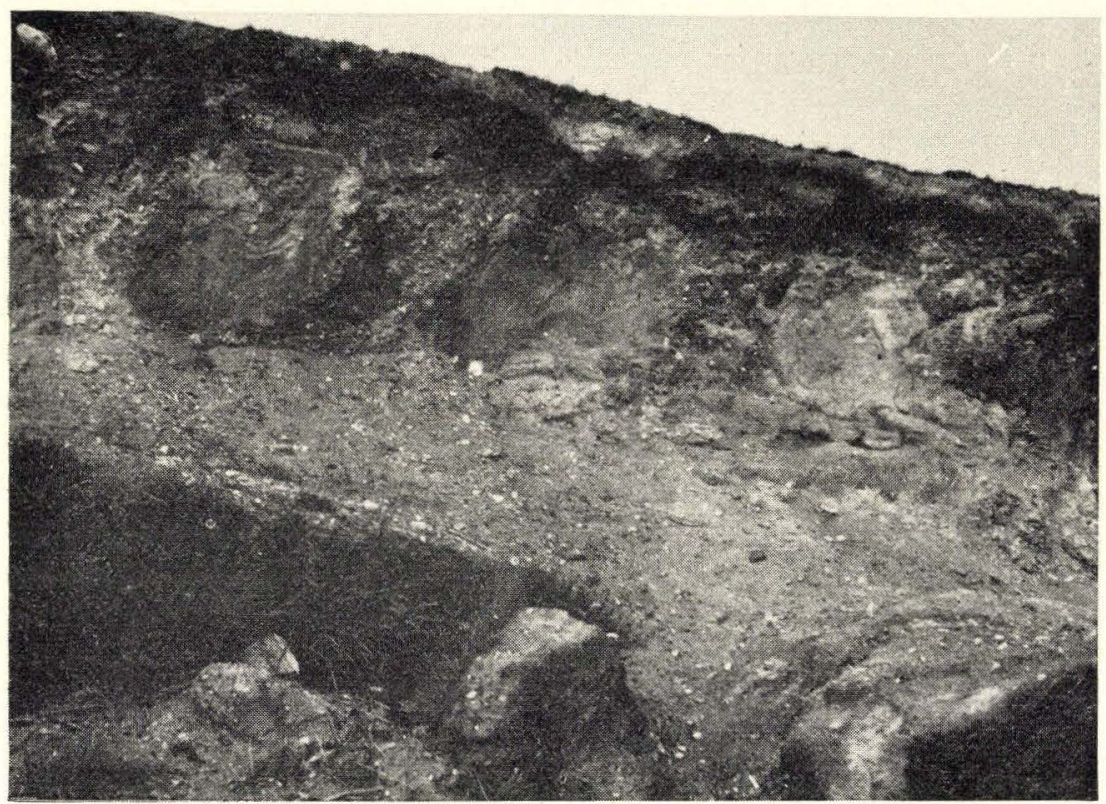

Fig. 6. Kklinten Øst for Esbjærg. Gryderne Nr. 45, 46 og 47. 
omhyggelig Undersøgelse af dem bringer næsten altid Brodelhorisonten for Dagen.

Ved mit Besøg i Oktober 1937 undersøgte jeg en ganske frisk Væg, dannet ved Afrømningsarbejder i Nærheden af det lille Hus, der ligger umiddelbart øst for Teglværkets store Tørrelader. Her fandtes, omtrent i Midten af denne ca. $1 \mathrm{~m}$ høje Væg, en Horisont af ovalt formede Sandboller, der var $10-20 \mathrm{~cm}$ høje og $30-40 \mathrm{~cm}$ lange. Leret, der laa over denne Horisont, lignede en Lokalmoræne. Det syntes væsentligst at bestaa af det stenfri Yoldialer, men indeholdt alligevel en Del mindre Sten. Allerede paa dette Tidspunkt mistænkte jeg disse Strukturer for at være et Solifluktionsfænomen; væsentlig fordi de syntes knyttet til en bestemt Horisont under Jordoverfladen, men ogsaa fordi de frembød en ret paafaldende Lighed med de poseformede Sandpartier, jeg kort Tid forinden havde iagttaget i Lergraven i Bramming, og som jeg paa det Tidspunkt var ret overbevist om dannede en Brodelhorisont. Det var imidlertid ikke dengang muligt at foretage nogen nøjere Undersøgelse af Skrænten, og da jeg atter besøgte Stedet i Juni 1938 var Væggen i Vinterens Løb fuldstændig skredet til. Ved en lille Udgravning, jeg lod foretage ca. $50 \mathrm{~m}$ syd for dette Sted, fandt jeg i samme Niveau lignende Sandpartier i Leret. Her viste de sig imidlertid at have en tydelig Grydeform. De var ligeledes paa dette Sted dækket af et ca. 0,50 m mægtigt Lerlag, indeholdende talrige Sten. Det ser efter dette ud til, at der oprindelig har været Brodelboden i den nordlige Del af Graven ogsaa, men at den er blevet ødelagt ved Jordflydning, hvorved det øverste morænelignende Ler er blevet placeret oven paa den tidligere Brodelboden.

Da jeg i 1938 atter besøgte Teglværksgraven, fandtes i dens sydvestlige Hjørne en ret uregelmæssig formet Næse, der sprang $20-25 \mathrm{~m}$ ind i Graven. Overjorden var paa dette Sted rømmet af, og her opdagede jeg paa det Stykke, der laa helt inde ved den ved Afrømningen fremkomne, men nu fuldstændig sammenfaldne Væg, at Terrassens Overflade var aaret af Lerstriber. Ved at forfølge disse Lerstriber, idet jeg skrabede Omraadet fri for $10-20 \mathrm{~cm}$ Fyld, viste det sig, at de dannede en aflang Ring, hvis største Akse strøg NNO-SSV. Lerstriberne forgrenede sig paa en saadan Maade, at man maa formode, at der op til denne Ring grænser andre af samme Størrelse. Inde i Ringen ligger der omtrent stenfrit, ret fint Sand, mens selve Ringens lerede Kanter er temmelig stenede. Ringen blev gennemgravet, og man saa da en smuk Gryde (Fig. 7), der ganske lignede de bedst udviklede af Gryderne, der ses i Klintprofilet. Her var Kammene imidlertid dannede af det marine Ler i Stedet for af Melsand som i Klinten. Paa Grund af Tipvognssporet var det ikke muligt at afdække de tilgrænsede Ringe paa dette Sted, jeg foretog en lille Udgravning i Terrassen et Par Meter Vest for Tipvognssporet. Det lyk- 


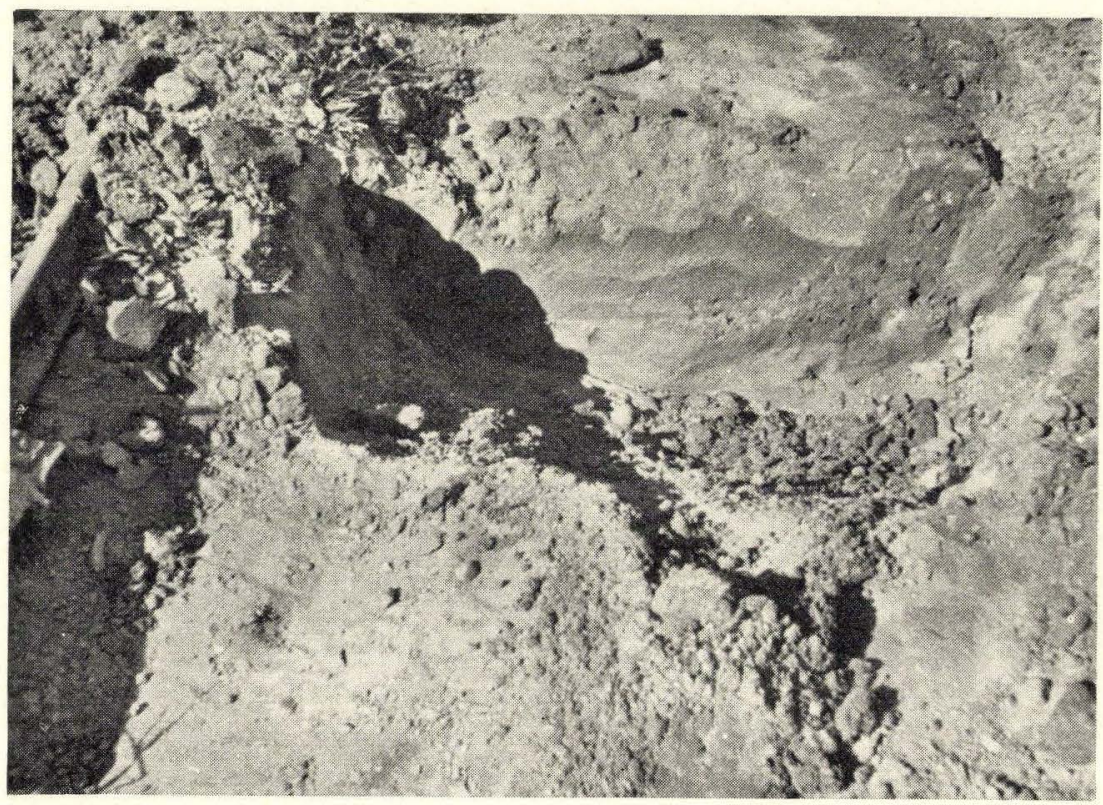

Fig. 7. Esbjærg Teglværk. Kam i vertikalt Snit. Man bemærker Grydestrukturen.

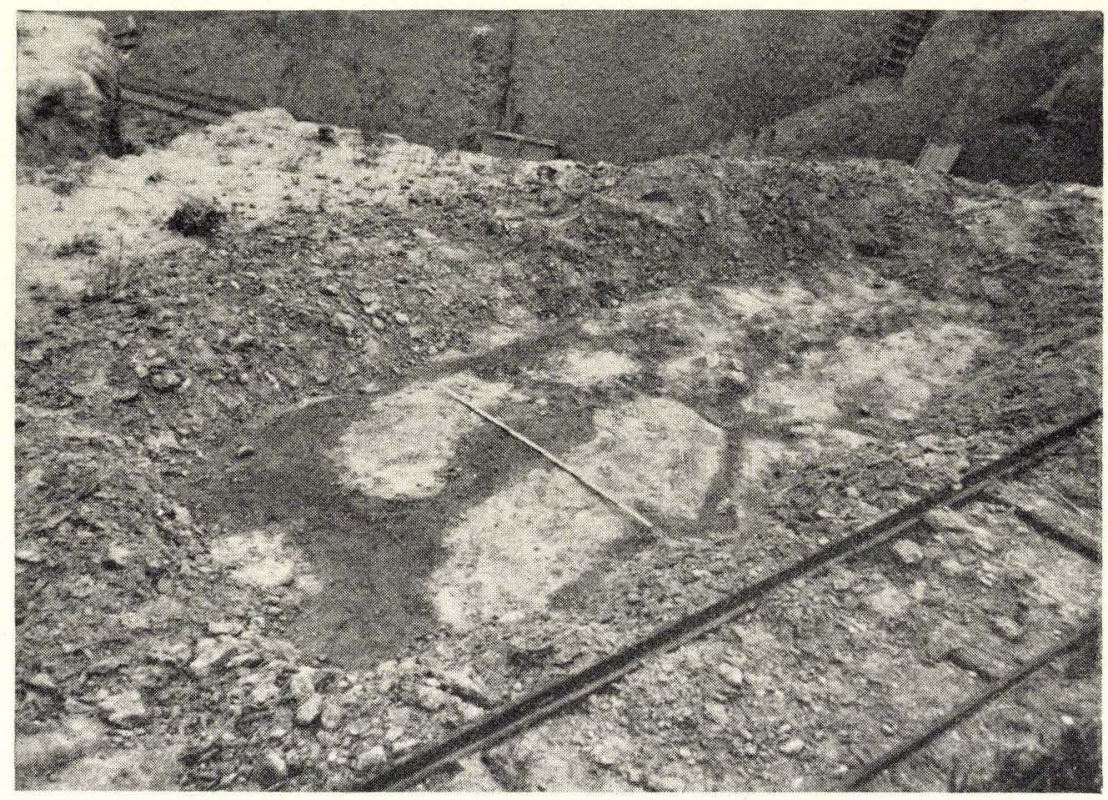

Fig. 8. Esbjærg Teglværk. Fortrukket Net. 
kedes her at afdække fire ovale Ringe, ca. $100 \mathrm{~cm}$ lange og $50 \mathrm{~cm}$ brede, tillige med mindre Partier af de tolv tilgrænsede Ringe (Fig. 8). Paa Grund af den dybtgaaende Afgravning syner Kammene mellem Ringene meget brede. Disse Kamme bestod ogsaa her af det marine Ler og var saa stenede, at de var vanskelige at afgrave og afglatte. Stenene laa særligt i Kanten af Lerkammene, og flere Steder kunde man iagttage, at de stod lodret.

3. Gammelby Teglværk.

Nogle faa hundrede Meter Øst for det gamle Teglværks nu forladte Grave umiddelbart ved Vejen til Darum er der anlagt et nyt lille Teglværk. Den i 1937 ca. to Aar gamle Grav Syd for Vejen ligger umiddelbart bag ved Teglværkets Sydside. Af Gravens Vægge er Vestvæggen, hvori der for Øjeblikket graves, den eneste, der er tilstrækkelig frisk til at fremvise noget af Interesse. Man ser her under $10-20 \mathrm{~cm}$ Muld en ca. $1 \mathrm{~m}$ mægtig Horisont af Rødler, der graves til Brænding af røde Tegl, saaledes at det nedenunder liggende Blaaler, der ikke bortgraves saa hurtigt, danner en ca. $10 \mathrm{~m}$ bred Terrasse i Graven. I Rødleret finder man temmelig mange Sten, der ser ud til at være nedpressede i Leret. De fleste af dem er nemlig tydelig rejst paa Højkant. I en Zone omtrent i Midten af det $1 \mathrm{~m}$ høje og omkring $100 \mathrm{~m}$ lange Profil i Rødleret ligger en Del Sandpartier af en temmelig uregelmæssig Form. Man ser dog sjældent Partier, der er mer end $30-40 \mathrm{~cm}$ lange og ca. $20 \mathrm{~cm}$ høje. Hvis man graver ind i Væggen, vil man imidlertid snart opdage, at vi ogsaa her staar over for en ganske smukt udviklet Brodelboden, af ganske samme Udseende som den i Graven umiddelbart Øst for Esbjerg. Ringene er her ca. $40 \mathrm{~cm}$ i Diameter, og Strukturmarken er altsaa ogsaa, ligesom det var Tilfældet i den tidligere omtalte Grav ved Esbjerg, ødelagt i sin øverste Del af senere Solifluktion. Brodelhorisonten lader sig følge igennem hele den $100 \mathrm{~m}$ lange Væg. Denne Grav er iøvrigt særlig interessant paa Grund af Frostspalterne, der ogsaa gennemsætter Brodelhorisonten. De er omtalt i en tidligere Afhandling (Norvang 1942).

\section{Lergrav ved Maade.}

Ca. $1 \mathrm{~km}$ Sydøst for Gammelby ligger der et ret stort Teglværk nede ved Stranden. De gamle Grave umiddelbart ved Teglværket er nu forladte og vandfyldte, og man graver nu i to nye Grave, hvoraf den fjerneste ligger ret langt øst for Teglværket, lige Syd for Maade. Her i denne Grav arbejdes for Tiden (1938) med Gravemaskine, saaledes at Leret skrælles af foroven og nedefter. Der er herved fremkommet en Slags Sydvæg, der er meget skraa, idet den hælder omkring $30^{\circ} \bmod$ Nord. Væggen er ca. $150 \mathrm{~m}$ lang. Som Følge af den ejendommelige Gravemaade ser man Strukturmarken midtvejs i Profilet som en enkelt Række ret uregel- 


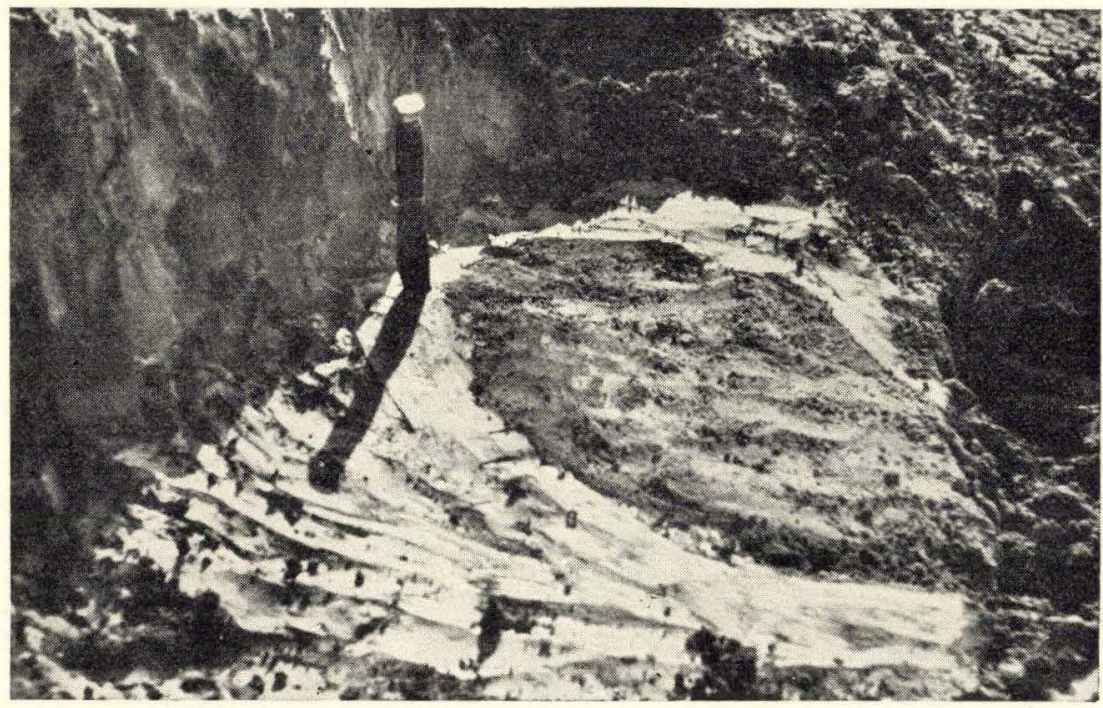

Fig. 9. Lergrav ved Maade. Horisontalt Indsnit i Væggen. Man bemærker den smukke Ringform.

mæssige Ringe. En af disse Ringe blev udgravet og afglattet (se Fig. 9). For at faa Strukturen til at fremtræde tydeligt paa Fotografiet, har jeg benyttet en særlig Fremgangsmaade. Hele Overfladen er afglattet saa jævnt som muligt. De lerede Kamme faar derved en blank og spejlende Overflade, mens Sandet, paa Grund af den større Kornstørrelse, tilbagekaster Lyset diffust. Billedet blev derefter taget i Modlys ved meget skraa Belysning henimod Solnedgang. Den regelmæssig reflekterende Leroverflade fremtræder derfor meget lys, mens det diffust reflekterende Sand tegner sig væsentlig mørkere. Denne Fremgangsmaade vil sikkert med Held kunne anvendes i lignende Tilfælde, hvor man ønsker at fotografere Grænselinien mellem et Sand- og et Lerlag, især hvor Lagene har nogenlunde samme Farve, og derfor ikke vil fremtræde tydeligt ved Fotografering paa almindelig Maade.

\section{Teglværk i Bramming Stationsby.}

Umiddelbart ved Teglværket, et Stykke Øst for Stationen i Udkanten af Byen, ligger der en Lergrav. Der graves for Tiden kun i den vestlige Del af den, hvor man ved mit Besøg i 1937 var i Færd med at bortgrave en Næse, der springer ind i Graven fra Nord, og som begrænses af to Vægge, der skærer hinanden i en Vinkel paa omtrent $45^{\circ}$. Næsens vestlige Begrænsning dannes da af en Væg, der i Forhold til Graven er en Østvæg; Væggen paa Næsens anden Side bliver saaledes en Nordvestvæg. Væggene er begge 3-4 m høje; Østvæggen er ca. $50 \mathrm{~m}$ lang; Nordvestvæggen er ca. $20 \mathrm{~m}$ lang. I Bunden af Graven 


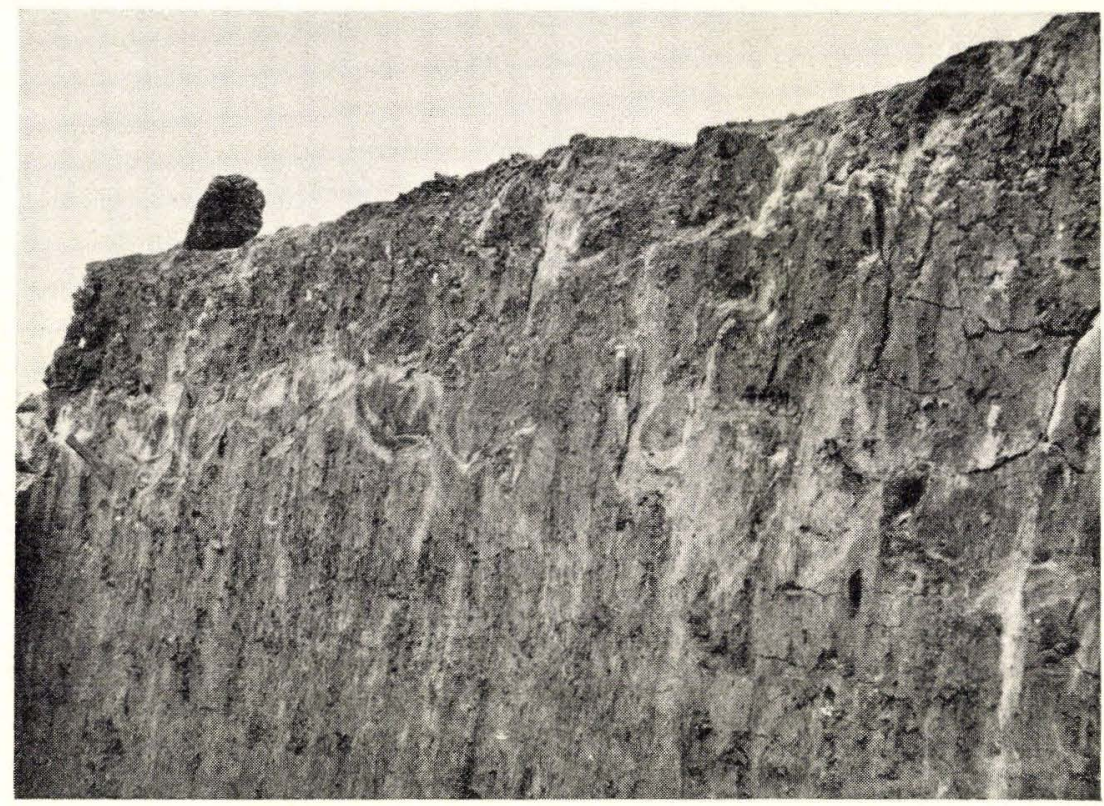

Fig. 10. Teglværket i Bramming. I den øverste Del af Væggen ser man Brodelhorisonten.

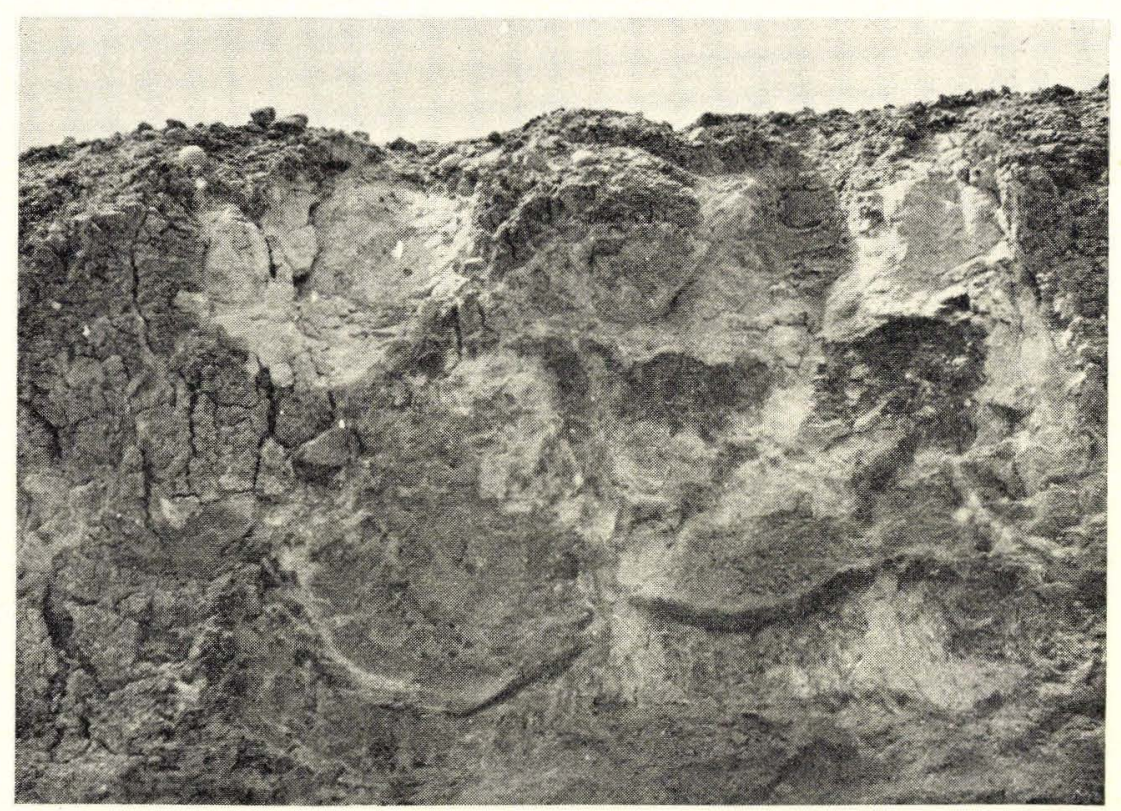

Fig. 11. Teglværket i Bramming. Parti af Brodelhorisonten. Man ser flere Generationer af Gryder, udviklet oven i hinanden. 
finder man helt sort Ler, der gør et overordentlig fedt Indtryk, naar man forsøger at grave i det. Ser man imidlertid nærmere paa det, vil man opdage, at det er fuldt af smaa Kvartskorn paa Størrelse med smaa Erter. Efter Sigende er der fundet Rødder i dette sorte Ler, mer end $3 \mathrm{~m}$ under Jordoverfladen. Opefter gaar det sorte Ler jævnt over i gulbrunt eller graat Ler, der er spættet af okkerrøde Pletter. Dette gulbrune Ler er ligeledes meget fedt, men indeholder trods dette temmelig mange Sten, der ligger spredt i Leret. Der findes dog utvivlsomt flest i den øverste Del af Leret over Brodelhorisonten. I dette øverste Afsnit af Leret er der ogsaa fundet to smukt vindslebne Kvartsiter. Hist og her i Leret finder man op til $2 \mathrm{~m}$ brede, ret uregelmæssige Sandpartier, der lader sig følge igennem hele Væggen. Den øverste Meter af det gulbrune Ler, umiddelbart under Mulden, indeholder talrige linse- eller poseformede Sandpartier (Fig. 10). Disse Sandlinser og -poser ligger mange Steder saa tæt ved hinanden, at Leret kun danner smalle Kamme, der adskiller Sandpartierne. Dette er særlig Tilfældet i de udpræget poseformede Sandpartier. Kammen har sædvanligvis i saa Tilfælde en Bredde af ca. $1 \mathrm{~cm}$. I denne Posehorisont er Leret betydelig mere stenet, og man iagttager ofte, at Stenenes Længdeakser ligger konformt med Posernes Inderflader, saaledes at Stenene altsaa staar paa Højkant i Kammene. Dette kan være Tilfældet med selv ret store Sten. Et enkelt Sted ser man endog en Sten paa Størrelse med et Barnehovede, der ligger indordnet paa denne Maade. Brodelhorisonten lader sig følge hele Vejen igennem begge Vægge. De øvrige Vægge i Graven er fuldstændig tilskredne og bevoksede. Brodelhorisontens Mægtighed er ret varierende, men overskrider i Almindelighed ikke en Meter. Ved nøjere Eftersyn vil man iagttage, at der flere Steder optræder flere Brodelhorisonter med Brodelkedler af omtrent samme Diameter oven i hinanden (Fig. 11). Brodelbevægelsen er altsaa sket samtidig med en Aflejring af den øverste Del af Leret, der bortset fra den noget rigeligere Forekomst af mindre Sten, kun i ringe Grad adskiller sig fra det underliggende Ler. Dette er Grunden til, at Strukturmarken her, ligesom visse Steder i Esbjerg Teglværks Grav, viser Poseformer i Stedet for de mere karakteristiske Gryder.

Nogle Steder ser man, at Brodelhorisonten bestaar af Sandlinser, der ligger paa Fladen i Leret. Leret over disse Sandlinser er tit saa stenet, at det gør et ganske moræneagtigt Indtryk. Ved at præparere nogle af disse Sandlinser frem, viste de sig at være fremkommet ved, at Profilvæggen har snittet poseformede Sandpartier ret yderligt. Vi finder altsaa her i Graven Forhold, der ganske svarer til Forholdene i Teglværksgraven i Esbjergs umiddelbare Nærhed. Kun er Fænomenerne her i Graven en Smule mere forstyrrede ved senere Solifluktion, idet der er akkumuleret saa meget Flydejord over den først dannede Strukturmark, at der visse Steder er uddannet en ny oven over den gamle. Ved hori- 

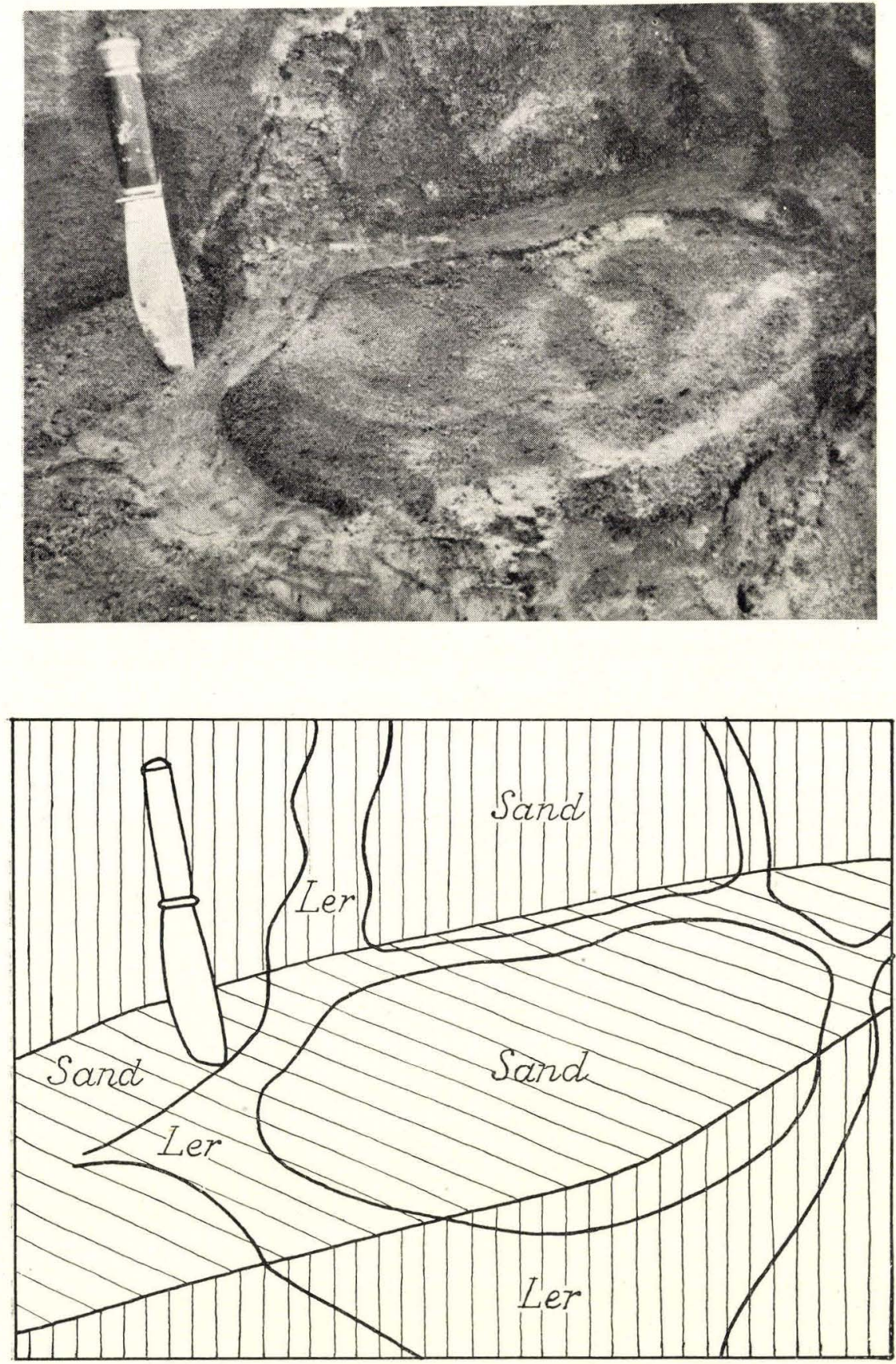

Fig. 12. Teglværk i Bramming. Vertikale Vægge lodret skraverede; horisontal Flade skraat skraveret. Bemærk Opdelingen i ringformede Partier, adskilte ved lerede og stenede Kamme. 
sontal Afgravning viste det sig, at Kammene dannede Ringe (Fig. 12), der omgav de sandede Partier. Stenene i Brodelhorisonten ligger ogsaa her i Lag, der beklæder Kammene. Man ser ingen Varvighed eller tydelig Lagdeling i Leret. Derimod ser man hyppigt mørkere, ret uregelmæssige Slirer og hist og her stærkt krøllede, ja endog lodretstillede Sandlag.

\section{Grav Vest for Bramming.}

I en lille Sandgrav ca. $1 \mathrm{~km}$ Nordvest for Bramming finder man ogsaa et Profil gennem en Brodelboden, der dog her fremtræder meget utydeligt. Væggen i Graven er en Nordvæg; den er ca. 2 m høj og $30 \mathrm{~m}$ lang. Nederst i Væggen ser man et $1 \mathrm{~m}$ mægtigt Lag af utydeligt lagdelt Sand med talrige spredte Sten og tynde Lag af Fingrus. Sandet er stribet af brede Ruststriber, der nogenlunde følger Lagfladerne. Opefter afsluttes denne Aflejring diskordant af et ca. $1 \mathrm{~cm}$ tykt Lerlag, der guirlandeformet kan følges gennem hele Aflejringen. Flere Steder danner Lerlaget $10-15 \mathrm{~cm}$ høje Kamme, der begrænser de 20-40 $\mathrm{cm}$ brede Gryder (Fig. 13). Herover ligger der et $0,75-1,00 \mathrm{~m}$ tykt Lag af leret Sand med spredte Sten, der gør et meget morænelignende Indtryk. Stenene er for Størstedelen temmelig smaa; de overskrider næppe Dueægstørrelse, og er som Helhed betydelig mindre, paa Størrelse med Hasselnødder. Det var paa Grund af Arbejdet i Graven ikke muligt at undersøge de enkelte Gryder i Væggen nøjere.

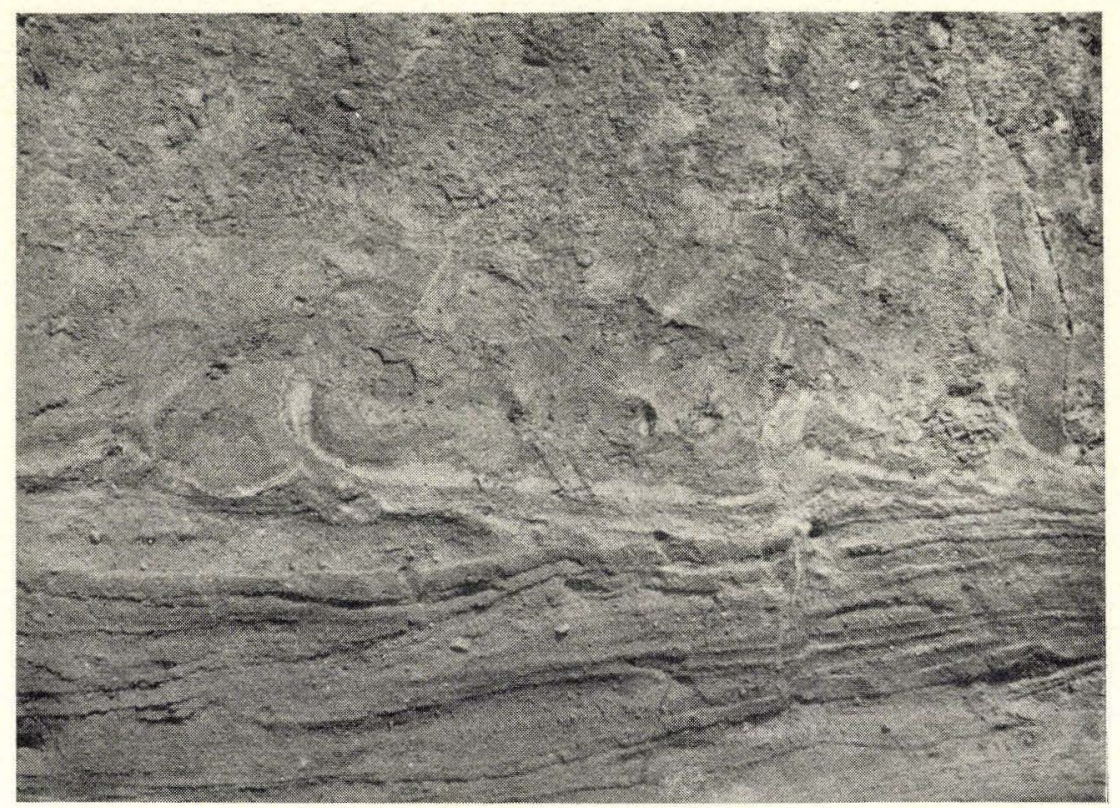

Fig. 13. Grav Vest for Bramming. Utydelig Brodelhorisont. 
7. Mergelgrav ved Hulvig.

Ved Hulvig ca. $15 \mathrm{~km}$ Nordøst for Varde fandtes en lille Mergelgrav. Man ser i en Vestvæg Gryder i stenet Sand over fedt Ler og rødligt, hvidspættet Sand. Teksturerne var ret utydelige og saas kun paa de Steder af Væggen, hvor de var blevet fremhævet ved Podsoleringen, idet Kammene var omdannet til en fast Sortal.

\section{Grusgrave ved Herning.}

Umiddelbart Sydvest for Herning By lige tæt Sydvest og Syd for Gasværket findes tre ret store Grusgrave. I den sydligste graves der for Tiden i en næsten halvcirkelformet Udskæring i Sydvæggen. I denne, ganske vist for største Delen tilskredne Væg, finder man ret groft, smukt lagdelt Sand, der hist og her indeholder mindre, linseformede Partier af Grus. Oven over dette Sand ligger et ca. $1 \mathrm{~m}$ mægtigt Lag af stenet Sand uden Lagdeling. Grænsen mellem dette Sand og det lagdelte Sand er skarp og tydelig. Det lagdelte Sand danner ligesom korte Tappe op i det ulejrede Sand, og i disse Tappe er Sandets Lagdeling ganske uforstyrret. Lagene afskæres derved diskordant af det ulejrede Sand, og det lagdelte Sand maa være dannet ved en Omlejring af det lagdelte Sand; thi ved nøje Eftersyn kan man se, at det ulejrede Sand danner en Horisont af mer eller mindre utydelige Brodelgryder, og »Skaarene« $\mathrm{i}$ Grænsefladen er i Virkeligheden kun Bunden af disse Gryder, der næsten alle har en Diameter af ca. $50 \mathrm{~cm}$. Staar man i Bunden af Graven, vil man desuden bemærke, at de fleste Sten i det ulejrede Sand staar paa Højkant, saaledes som man i Almindelighed finder det i Brodelhorisonterne.

I den mellemste Grav, der ligger tæt op til den ovenfor omtalte, graves der for Øjeblikket kun i Gravens Bund, hvorfor Væggene er meget nedskredne. I den vestlige Del af Sydvæggen ses imidlertid et ret ubetydeligt Profil, i den øverste Del af Væggen, er der ret tydelige Gryder. En enkelt af dem blev undersøgt nøjere. Ved at grave horisontalt ind i den øverste Del af Gryden kunde man se, at Gryden er snittet af Profilvæggen i sin østlige Ende. I de utydelige Gryder i den sydlige Grav kan man ikke finde nogen tydelig Kornstørrelseforskel mellem Sandet i Gryderne og i Kammene, men her i denne Grav indeholder Gryderne betydelig finere Sand end Kammene. At Gryderne iøvrigt fremtræder saa tydeligt her, skyldes, at Sandet i dem er rødfarvet af Rustdannelser. I den sydlige Grav er Gryderne kun antydet ved Ruststriber. Ingen af de her omtalte Profiler er imidlertid saa gode, at man føler sig overbevist om at staa over for en virkelig Brodelhorisont. Ostligst i den nordligste af de tre Grave ses imidlertid et smukt Profil, der afgør Problemet. Man ser her en lille Indgravning i Østvæggen, hvorved der fremkommer tre Vægge; 
en Nordvæg, ca. $3 \mathrm{~m}$ høj og $3 \mathrm{~m}$ lang; en Østvæg og en Sydvæg af omtrent de samme Dimensioner. Nordvæggen, der er gravet igennem en tidligere, nu igen opfyldt, Udgravning, fremviser følgelig intet af Interesse. I Sydvæggen og Østvæggen ser man imidlertid otte Brodelgryder, der hver er $50-100 \mathrm{~cm}$ brede og adskilte af smalle Kamme, hvori man ser mange lodret stillede Sten. Gryderne er fyldt med groft Sand, der indeholder en hel Del Smaasten paa Størrelse med Nipsenaalehoveder. Kammene bestaar af stærkt leret Materiale, hvad der særlig ses tydeligt i Sydvæggen. I denne Væg er de $5-10 \mathrm{~cm}$ brede og indtil $75 \mathrm{~cm}$ høje, hvorimod de i Østvæggen kun naar en Højde af ca. $30 \mathrm{~cm}$. Kammene bestaar af nævestore Sten, og hist og her ser man endda Sten paa Størrelse med et Barnehovede. Selv saa store Sten kan være rejst paa Højkant. Opadtil gaar Gryderne over i stenet Sand, der umiddelbart under det ca. $30 \mathrm{~cm}$ tykke Pløjelag indeholder en smuk Stenhorisont, hvis Sten i enkelte Tilfælde er større end en knyttet Næve. Nederst i Profilet under Brodelhorisonten ser man ca. $1 \mathrm{~m}$ lagdelt Grus.

I en lille Grav, der ligger noget Syd for disse tre Grave helt nede ved Jernbanen, ser man ligeledes en utydelig Brodelhorisont. Graven er imidlertid nu saa stærkt tilskreden, at det er umuligt at foretage nogen nøjere Undersøgelse af den.

\section{Grusgrav ved Troldhede.}

Ca. $1 \mathrm{~km}$ Nordnordvest for Troldhede Stationsby, omtrent paa Vondaaens Sydskrænt, Syd til Sydvest for de gamle Brunkulsgrave, ligger der en 2-300 m lang og ca. $15 \mathrm{~m}$ bred Grav i Hedegrus (Fig. 14). Gravens Længdeakse stryger omtrent NV-SO. I Sydvestvæggens Hedegrus og Sand ses flere Steder en smuk Skraalejring, der viser, at Smeltevandet, der har aflejret dette Materiale, er løbet i sydøstlig Retning. Godt $100 \mathrm{~m}$ Øst for Vejen, der løber umiddelbart forbi Gravens Nordvestende, er der i den ellers ret tilskredne Væg et smukt ca. $30 \mathrm{~m}$ langt og godt $2 \mathrm{~m}$ højt Profil. Man ser nederst i Profilet smukt lejret Fingrus. Laget har en Mægtighed af mindst $1 \mathrm{~m}$. Derover ligger der et mod Sydvest udkilende Lag af leret, stenet Sand. Dette morænelignende Lag har et ejendommeligt smaabænket Udseende, og man lægger især Mærke til, at alle de smaa Sten i det ligger paa Fladen, saaledes at Leret fuldstændig ligner en Grundmoræne. Lerets finbænkede, næsten bladede Karakter skyldes sikkert et ret betydeligt Indhold af Glimmer. Her i dette graa, faste, moræneagtige Ler findes en Brodelhorisont. Over Laget ligger der et ca. $10 \mathrm{~cm}$ tykt Lag af stenet Dæksand uden tydelig Tekstur. Dette Dæklag ligner ganske det stenede Sand, man ser i Gryderne, naar man ser bort fra, at Sandet i Bunden af Gryderne ofte kan vise en ejendommelig Lagdeling, idet Lagene ligger konformt med Grydens Inderflade. Oven 


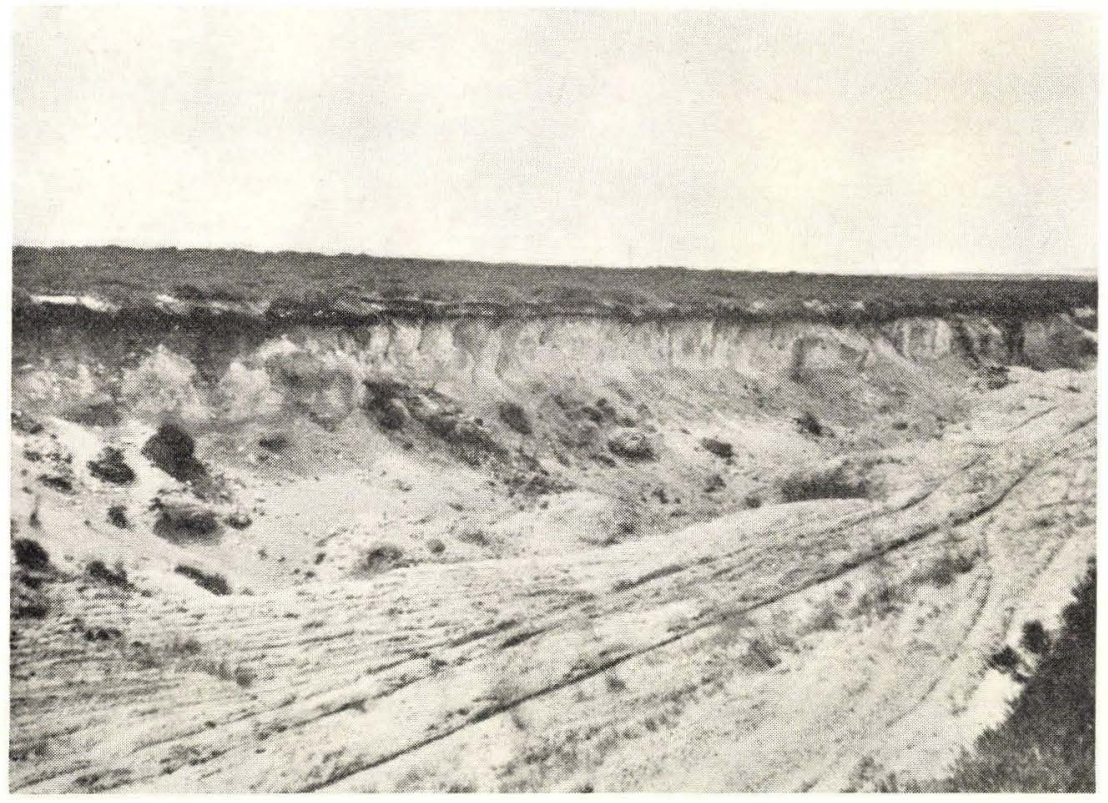

Fig. 14. Grusgrav ved Troldhede. Man ser Væggen med Brodelhorisonten.

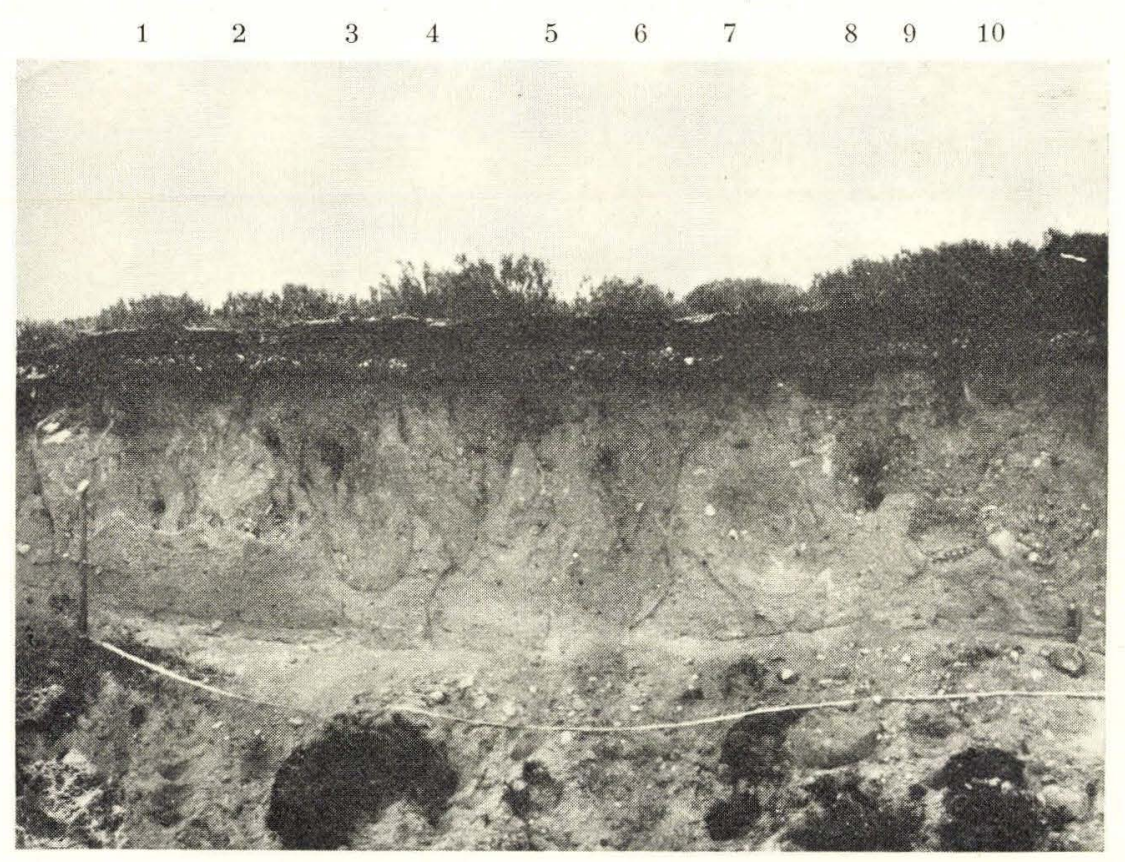

Fig. 15. Grusgrav ved Troldhede. Gryderne Nr. $1-10$.

Danmarks Geologiske Undersøgelse. II. R. Nr. 74. 
paa dette Sand hviler der et ca. $2 \mathrm{~cm}$ tykt Lag af sort Al. Herover findes et tyndt Lag af mørkt Blegsand, der ca. $1 \mathrm{~cm}$ over Alen indeholder et Stenlag. Allerøverst ser man en tynd Lyngskjold.

I den 5-6 $\mathrm{m}$ lange, nordøstlige Del af Væggen ser man ingen tydelige Gryder, men derimod nogle enkeltvis liggende, smalle Nedposninger fra det stenede Sand. Ved mine Besøg i Graven lagde jeg ingen særlig Vægt paa denne ganske utypiske Udformning af Horisonten i dens Udkant, men efter senere at have set ganske lignende Fænomener i Nørre Uttrup Teglværks Grav — som er nærmere beskrevet S. 49 - har jeg faaet det Indtryk, at denne Udformning er karakteristisk for Yderpartierne af Brodelhorisonten.

Den første tydelige Gryde, man ser, naar man gaar fra Nordøst mod Sydvest langs Profilet, er betegnet som Nr. 1.

Gryde Nr. 1 er $65 \mathrm{~cm}$ dyb og ca. $30 \mathrm{~cm}$ bred paa det bredeste Sted (Fig. 15). Paa dette Sted er Gryden delt i en øvre og: en nedre Del ved en horisontal, ca. $5 \mathrm{~cm}$ tyk Lerflage, der adskiller et nederste, stenet Parti fra selve Hovedgryden, som er fyldt med rødligt Sand. Langs Grydens Vægge ser man talrige Smaasten paa Størrelse med Dueæg; de staar alle paa Højkant. I den nedre Del af Gryden under Lerflagen ser man, at Stenene her ligger konformt med Grydens Inderflade. Gryden blev udgravet, og det viste sig herved, at den fortsæetter som et Trug mer end $0,50 \mathrm{~m}$ ind i Væggen. Den stryger ca. $\mathrm{N} 20^{\circ} \varnothing$., parallelt med Vondaaens Sydskrænts Hældningsretning.

Gryde Nr. 2 er ca. $40 \mathrm{~cm}$ bred og $50 \mathrm{~cm}$ dyb. Den viser sig kun som et guirlandeformet Stenlag (Fig. $15 \mathrm{og}$ 16). Selve Gryden er nemlig fyldt af moræneagtigt Ler af ganske det samme Udseende som det, man finder under og imellem Gryderne.

Gryderne Nr. 3 og 4 er begge fyldt med rødligt Sand og er adskilte fra hinanden ved en ca. $30 \mathrm{~cm}$ høj Kile af det graa, morænelignende Sand (Fig. $15 \mathrm{og} \mathrm{16)}$. Nr. 3 er ca. $85 \mathrm{~cm}$ dyb og knapt $50 \mathrm{~cm}$ bred paa det bredeste Sted. Man ser flere Steder enkelte kantstillede Sten langs Grydernes Sider. Der blev foretaget en mindre Indgravning i Gryden og herved iagttoges det, at Kammen, der adskiller de to Gryder, fortsætter i en Bue ind i Væggen, til den løber sammen med Kammen mellem Nr. 2 og Nr. 3. Det var ikke muligt at finde Tegn paa nogen Forgrening af Kammen. Visse Partier af Kammen er saa stenede, at den er vanskelig at grave i. Nr. 4 er en ret smal Gryde. Den naar ned i samme Dybde som Nr. 3, men er kun $20 \mathrm{~cm}$ bred. Ved at grave ind i Nr. 4, kunde det paavises, at den bliver bredere indefter. Mens Nr. 3, som ovenfor omtalt, er skaaret af Profilvæggen i sin Sydspids, saa er Nr. 4 altsaa snittet i sin Nordende. Fra den nordøstlige Del af Gryden fortsætter en ca. $1 \mathrm{~cm}$ bred, sandfyldt, ret uregelmæssig Spalte ned i det underliggende, moræreagtige Sand. 
Gryde Nr. 5 ses som en afrundet Klat Grus i Profilvæggen (Fig. 15 og 16). Den er ca. $20 \mathrm{~cm}$ i Diameter og ligger i et noget højere Niveau end de omgivende Gryder. Ved et enkelt Spadestik lod den øverste Halvdel af Gruspartiet sig let fjerne. Her har Profilvæggen altsaa snittet en trugformet Gryde i dens yderste Sydspids.

Gryde Nr. 6 er ca. $100 \mathrm{~m}$ dyb og $40 \mathrm{~cm}$ bred (Fig. $15 \mathrm{og}$ 16). Den er en Smule forsnævret paa Midten af to Volde, der stikker ind i Gryden. De bestaar af det graa, moræneagtige Ler, men adskiller sig alligevel tydeligt fra det omgivende, graa Ler, idet de ikke viser den karakteristiske smaabladede Tekstur og har en noget mere rødlig Farvetone. Gryden er iøvrigt fyldt med det samme rødlige Sand som de foregaaende. Spredt i Sandet ser man en Del Sten. De findes særlig talrigt i den øverste Tredjedel af Gryden og er næsten alle tydelig vendt paa Højkant.

Gryde Nr. 7. Som Gryde Nr. 7 er betegnet en skaalformet Fordybning i Profilvæggen (Fig. 15). Den har oprindelig været fyldt med Sand eller andet løst Materiale, der nu er blæst væk, og har altsaa opriudelig set ud som en normal Gryde. Man ser endnu tydeligt, at den har været poseformet i Gennemsnit, og at dens nuværende Form skyldes det skæve Snit; idet den er temmelig dyb i sin nedre Del og bliver jævnt fladere opadtil. Her skæres Grydens bageste Begrænsning i en meget lille Vinkel af Profilvæggen.

Gryderne Nr. 8, 9, 10 og 11 danner tilsammen et ejendommeligt Kompleks (Fig. 15). Nr. 8 er kun en lille Gryde; den er ca. $40 \mathrm{~cm}$ dyb og $20 \mathrm{~cm}$ bred og er ikke tydelig skilt fra Nr. 9, der ligger i et noget højere Niveau. Som Følge heraf kommer den nedre Del af Nr. 8 til at grænse direkte op til Nr. 10's nederste Del, kun adskilt fra denne ved en ca. $15 \mathrm{~cm}$ høj og omtrent lige saa bred Kam af det graa Ler. Denne Kam løber i sit øverste sydvestlige Hjørne ud i en 30—40 cm lang, kun nogle faa Centimeter bred Bjælke, der bueformet løber opad mod Sydvest og derved danner Grænsen mellem Nr. 9, der er flad, skaalformet, og den temmelig dybe Gryde Nr. 10. Nr. 10 gaar ca. $25 \mathrm{~cm}$ ned under denne bueformede Kam. Gryden er $35 \mathrm{~cm}$ bred og fyldt med Grus, der i Midten indeholder en $7 \mathrm{~cm}$ høj og $15 \mathrm{~cm}$ lang Sandlinse. Stenene ligger tydelig parallelt med Grydens Inderflade. Gryde Nr. 10 er skilt fra Nr. 11 ved en barnehovedstor Kvarsit. Nr. 11 har omtrent de samme Dimensioner som Nr. 10 og er ligesom denne fyldt med groft Sand. Langs Nr. 11's Sider finder man kun enkelte, spredte Sten, som alle er rejst paa Højkant.

I den herpaa følgende $2 \mathrm{~m}$ lange Del af Væggen findes kun faa og utydelige Gryder.

Gryderne Nr. 12 og 13. Det er temmelig tvivlsomt, om disse to Nedposninger med Rette kan opfattes som Gryder. Som Nr. 12 er betegnet et afrundet Parti af Grus, der er godt $20 \mathrm{~cm}$ i Diameter. Den har nogenlunde det samme Udseende som de ovenfor beskrevne Gryder Nr. 5 og 


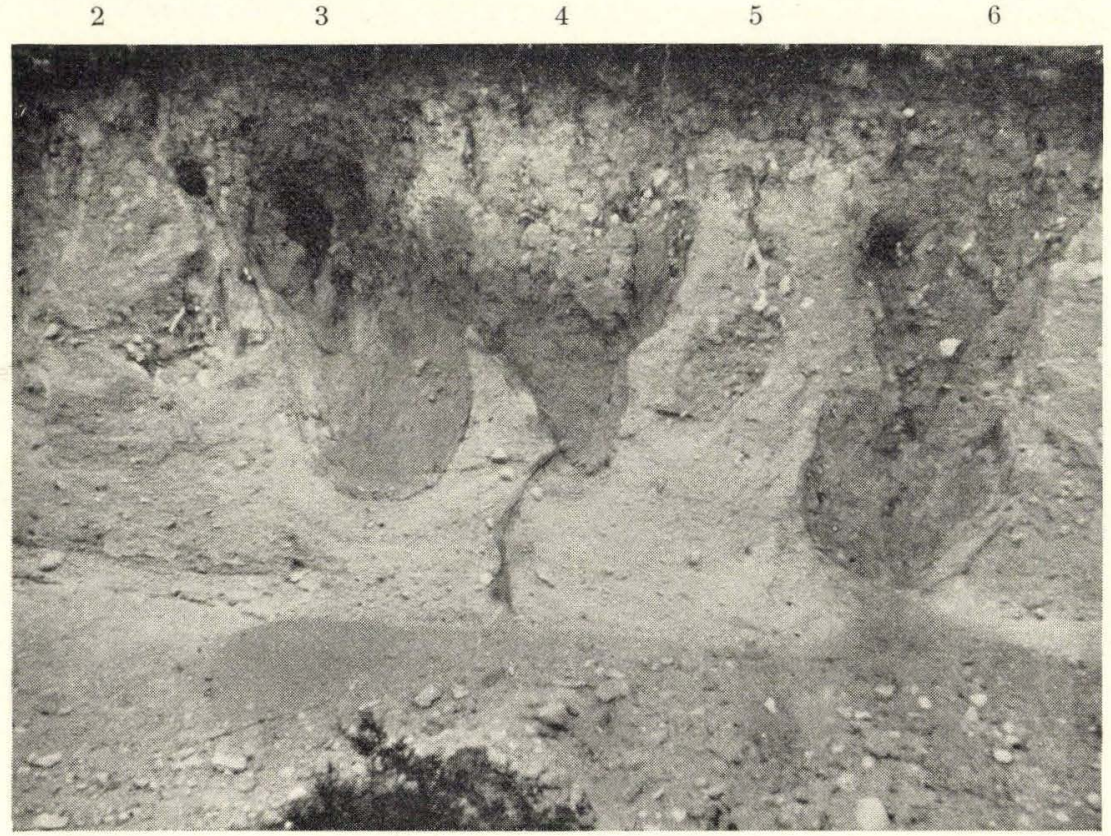

Fig. 16. Grusgrav ved Troldhede. Gryderne Nr. 2-7.

20

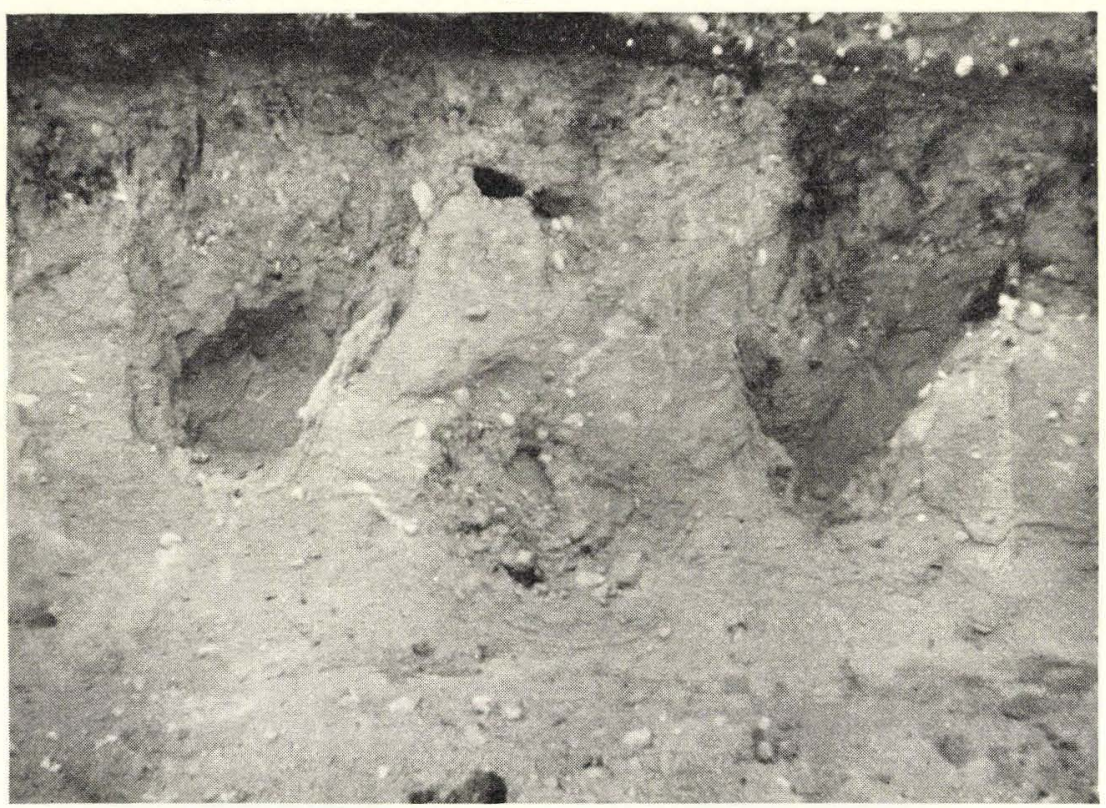

Fig. 17. Grusgrav ved Troldhede. Gryderne Nr. $20-22$. 
Nr. 7, men er noget mindre. Nr. 13 er derimod en ganske uregelmæssig Nedposning af det stenede Sand og viser ingen typiske Grydekarakterer. Den er ca. $50 \mathrm{~cm}$ dyb og $20 \mathrm{~cm}$ bred i sin nedre Del. Største Delen af Nedposningen er udfyldt af en stor, firkantet Kvarsitblok.

Gryde Nr. 14 er en ganske lille Gryde. Den er ca. $40 \mathrm{~cm}$ dyb og $15 \mathrm{~cm}$ bred; den er fyldt med stenet Sand.

Gryde Nr. 15 er en nogenlunde tydelig og typisk Gryde. Den er ca. $60 \mathrm{~cm}$ dyb og $30 \mathrm{~cm}$ bred. $30 \mathrm{~cm}$ nede er den delt i to af en tynd Bjælke af det moræneagtige Materiale. Den nordøstlige Del af Gryden er fyldt med Sand, der indeholder Sten større end Dueæg. De ligger alle parallelt med Grydens Sider. Den sydvestlige Del er fyldt med groft Sand uden Sten.

Gryde Nr. 16 er ogsaa en lille, temmelig utydelig Gryde, hvilket sikkert skyldes, at største Parten af den ligger oppe i det stenede Sand. Den er kun $40 \mathrm{~cm}$ dyb og $20 \mathrm{~cm}$ bred.

Gryderne Nr. 17 og 18 er derimod to smukke og typiske Gryder. De naar begge mer end $70 \mathrm{~cm}$ ned under Pløjelaget. Nr. 17 er knapt $30 \mathrm{~cm}$ bred. Nr. 18 er noget bredere, omkring $35 \mathrm{~cm}$ bred. De er begge fyldt med rødligt Sand og er adskilte fra hinanden ved en tydelig Kam, der bestaar af det graa, morænelignende, faste Sand. Den er mellem $20 \mathrm{og}$ $30 \mathrm{~cm}$ høj og ca. $5 \mathrm{~cm}$ bred. Gryderne blev tømte. Nr. 17 viste sig herved at gaa ca. $40 \mathrm{~cm}$ ind i Væggen. Nr. 18 blev tømt for Sand indtil $60 \mathrm{~cm}$ ind i Væggen, uden at man noget Steds saa den mindste Antydning af, at Sidekammene konvergerer. De stryger begge $\mathrm{S} 40^{\circ} \mathrm{V}$.

Gryde Nr. 19. Som Gryde Nr. 19 er betegnet et rundt Grusparti af ganske samme Udseende som Nr. 5, 7 og 12. Den er ca. $20 \mathrm{~cm}$ i Diameter. Den lod sig grave helt væk ved nogle faa Spadestik; gik altsaa kun ca. $10 \mathrm{~cm}$ ind i Væggen og maa ligesom de foregaaende opfattes som en Gryde, der er skaaret i sin sydlige Spids.

Gryde Nr. 20 er ca. $75 \mathrm{~cm}$ dyb og $45 \mathrm{~cm}$ bred (Fig. 17). Den er fyldt med rødligt Sand, der ude langs Kanterne bliver noget stenet af nøddestore Sten, hvis Længdeakser ligger parallelt med Grydens Inderflade. Gryden viste sig ved Udgravning at gaa $40 \mathrm{~cm}$ ind i Væggen, uden at man kunde iagttage nogen Indsnævring af den. Indefter bliver Kammene meget stenede.

Gryde Nr. 21. Som Gryde Nr. 21 er betegnet et ovalt Parti af Grus, der er ca. $35 \mathrm{~cm}$ højt og $45 \mathrm{~cm}$ bredt (Fig. 17). Stenene i Gruset ligger tydelig konformt med Partiets Grænseflade. Gryden lod sig følge $30 \mathrm{~cm}$ ind i Væggen, hvor den pludselig ophørte. Den maa derfor opfattes som en poseformig Gryde, skaaret af Profilvæggen i sin sydlige Ende.

Gryde Nr. 22 er ca. $70 \mathrm{~cm}$ dyb og $35 \mathrm{~cm}$ bred; den er fyldt med rødligt Sand (Fig. 17). I dens nordøstligste Hjørne ser man dog et lille Parti af Grus. Et Par Steder kan man se, at Stenene ligger parallelt med 
Grydens Sider. Der blev foretaget en Indgravning i Gryden, hvorved det viste sig, at den kunde forfølges mer end $80 \mathrm{~cm}$ ind i Væggen, uden at der viste sig noget Tegn paa, at den indsnævres indefter. Dens Akse stryger $\mathrm{N} 40^{\circ} \varnothing$.

Gryde Nr. 23 er en ganske lille Gryde. Den er $40 \mathrm{~cm}$ dyb og $20 \mathrm{~cm}$ bred, men har iøvrigt typisk Form.

Gryde Nr. 24 er en smuk og tydelig Gryde. Den er ca. $100 \mathrm{~cm}$ dyb og $35 \mathrm{~cm}$ bred. Formen er noget uregelmæssig, men alligevel ganske typisk. Den er ligesom de ovenfor omtalte Gryder fyldt med rødligt Sand, der dog i Midten indeholder et fingruset Parti. Stenene er for største Delen rejst paa Højkant baade i Grydens Midte og langs dens Sider.

Gryde Nr. 25. Som Gryde Nr. 25 er betegnet et lille, linseformet Sandparti, der ligger ca. $10 \mathrm{~cm}$ under Pløjelaget og har en Bredde af ca. $35 \mathrm{~cm}$ (Fig. 18). Ved Indgravning i dette Sandparti viste det sig, at det blev større indefter og hurtigt nærmede sig en mere typisk Grydeform, efterhaanden som man fjernede Lag efter Lag. Her ser man altsaa en Gryde, der er ramt af Profilvæggen i sin nordlige Ende.

Gryderne Nr. 26 og 27 er to smukke Tvillinggryder, der er adskilte ved en $35 \mathrm{~cm}$ høj og $10 \mathrm{~cm}$ bred, tilspidset Kam (Fig. 18). De naar begge ned i en Dybde af $80 \mathrm{~cm}$ under Blegsandet og er $25 \mathrm{~cm}$ brede. De er fyldt af næsten stenfrit Sand, hvori man ser en smuk Lagdeling parallel med Grydernes Sider.

Gryde Nr. 28 er en lille, meget ødelagt og temmelig utypisk Gryde, hvilket sandsynligvis skyldes Regnvandets Udskylning. Den er omtrent kileformet i Snit, og naar ca. $60 \mathrm{~cm}$ ned under Blegsandets Undergræense. Ved Indgravning i Gryden viste det sig, at den alligevel har en ganske typisk Form. Dens Bredde er efter Afgravningen ca. $20 \mathrm{~cm}$ umiddelbart over Bunden. Den tilsyneladende Kileform skyldes, at Regnvandet har udgravet en lille Rende i dens Bund.

Gryde Nr. 29 naar $75 \mathrm{~cm}$ ned under Blegsandets Underkant. Den er kun $30-35 \mathrm{~cm}$ bred, men har til trods for denne ringe Bredde en smuk typisk Form. Den er fyldt med Sand, der langs Grydens Kanter er stærkt stenet. Denne Gryde er en af de sidste typiske Gryder i Horisonten.

Længere mod Sydvest bliver det stenede Sand endnu mere stenet og gaar efterhaanden jævnt over i et Lag af ulejret Grus, samtidig med at Morænelerslaget bliver stadig tyndere og til sidst kiler fuldstændig ud. Ca. 5,50 m Sydvest for Gryde Nr. 29 ser man igen nogle faa Gryder i Horisonten. De er dog alle med en enkelt Undtagelse saa utydelige, at de ikke lader sig tælle og nummerere, endsige opmaale.

Gryde Nr. 30. Den ene af disse Gryder, der var nogenlunde tydelig, er betegnet som Nr. 30, selv om der imellem denne og Nr. 29 ligger et ubestemmeligt Antal utydelige Gryder. Den naar $90 \mathrm{~cm}$ ned under Blegsandets Underkant og er $50 \mathrm{~cm}$ bred. Den har en overordentlig smuk og 


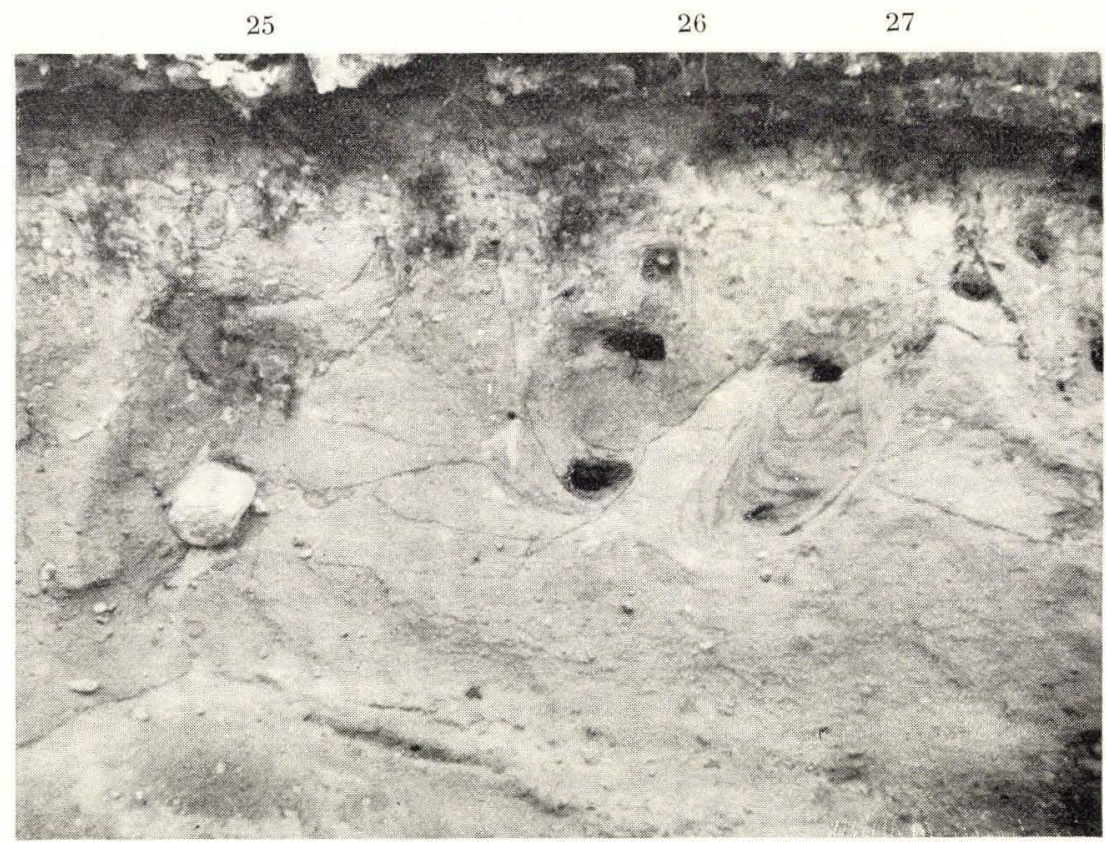

Fig. 18. Gryderne Nr. 25-27. Grusgrav ved Troldhede.

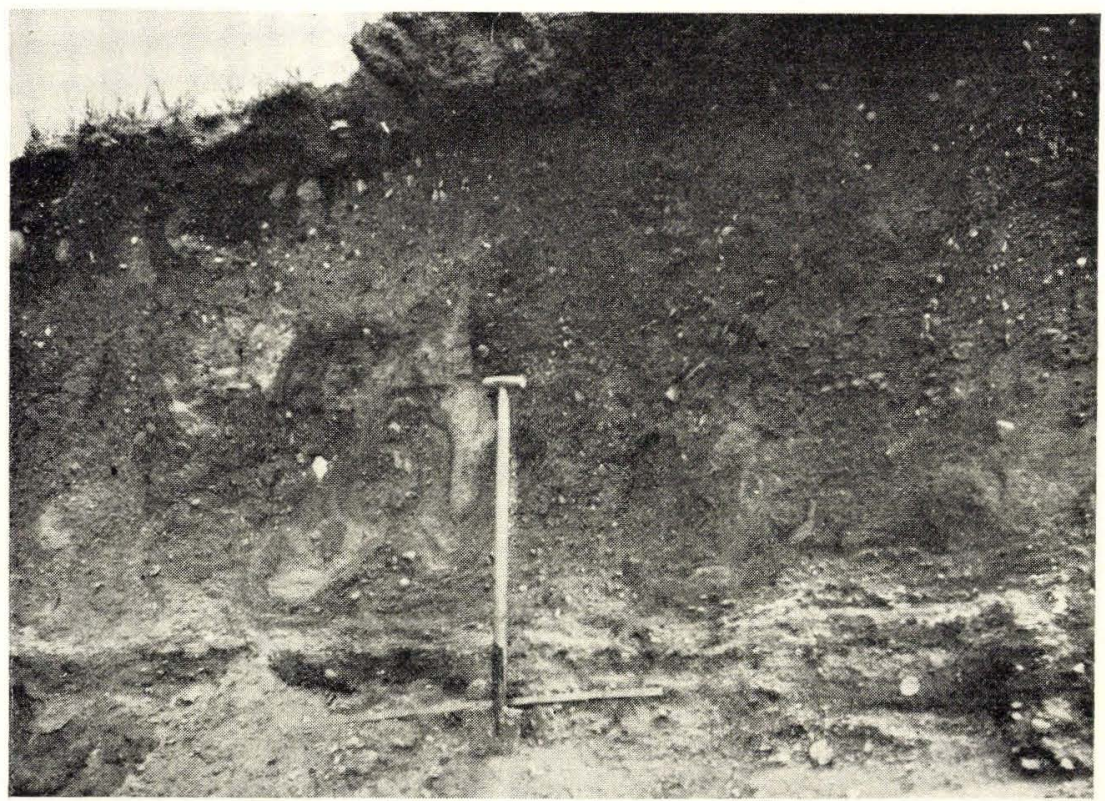

Fig. 19. Grusgrav ved Mørup. Nordvæg. Parti af Brodelhorisonten. 
typisk Grydeform, og er fyldt med det samme rødlige Sand som de andre Gryder. Langs dens Sider og Bund ser man mange Smaasten, der alle ligger parallelt med Grydens Sider.

$15 \mathrm{~m}$ fra Gryde Nr. 29 opmaaltes følgende Profil:

1. $0-0,05$ Lyngskjold.

2. $0,05-0,20$ mørkebrunt løst Sand.

3. $0,35-0,40$ Stenlag, indeholdende store Sten paa Størrelse med en Knytnæve. Hovedparten af Stenene er dog noget mindre. Der ses en Del Sten paa Størrelse med et Hønseæg.

4. 0,40-0,50 morænelignende, graat Sand.

5. $0,50-1,50$ Smeltevandsgrus.

Det morænelignende graa Sand maa opfattes som en Pseudomoræne, der er anbragt over Hedeslettegruset ved Jordflydning. Der er derefter uddannet en Strukturmark i dette graa Ler, der har været mere fugtigt end Hedegruset.

\section{Grusgrav ved Mørup.}

Lidt Nord for Mørup, hvor Terrænet skraaner jævnt ned mod Rind Aa, ligger der paa den østlige Side af Vejen mod Nord til Snejbjerg en Grusgrav, hvori man kan se en for Størstedelen ret utydelig, men dog sikkert erkendelig, Brodelhorisont.

Man ser i denne Grav to Vægge, en Nordvæg og en Østvæg, hvori der stadig bliver gravet, og som derfor ikke er tilskredne. Nordvæggen er $5-5,70 \mathrm{~m}$ høj og $80 \mathrm{~m}$ lang. Den er delt i to Vægge af en $20 \mathrm{~m}$ bred Næse, der springer ca. $3 \mathrm{~m}$ ind i Graven. Man ser i Væggen hovedsagelig Fingrus, hvori man af Skraalagene kan se, at den aflejrede Strøm er løbet mod Vest. Over dette Fingrus og skarpt afgrænset fra det ligger der ca. $1 \mathrm{~m}$ rødligt Sand, umiddelbart overdækket af et ca. $50 \mathrm{~cm}$ tykt blegsandet Muldlag. I dette rødlige, temmelig fine Sand, der er sammenkittet til en ret fast Al, findes Brodelhorisonten. Særlig ser man i den vestlige Side af Næsen fire smukke Gryder, som var saa tydelige, at de let lod sig opmaale (Fig. 19). Den Gryde, der er betegnet som Nr. 1 er den vestligste.

Gryde Nr. 1 er delt i tre mindre Gryder. Den vestligste

Sekundærgryde Nr. 1 er utydelig og utypisk. Den naar $1 \mathrm{~m}$ ned under Jordoverfladen og er paa det bredeste Sted ca. $40 \mathrm{~cm}$ bred. Den er fyldt med stenet Sand, der i Grydens vestligste nedre Del bliver ganske stenfrit.

Sekundærgryde Nr. 2 er mere typisk i sin Form. Den er fyldt med fint Sand, der er ganske stenfrit. Man ser tydeligt, at Stenene i Kammen ligger konformt med Grydens Inderflade. Gryden naar ned i en Dybde af 1,25 $\mathrm{m}$ under Jordoverfladen. Den er $40-45 \mathrm{~cm}$ bred paa det bredeste 
Sted. Den er adskilt fra Nr. 1 og Nr. 3 ved ret lave, ikke mer end $50-60 \mathrm{~cm}$ høje, Kamme. Kammen imellem Nr. 1 og Nr. 2 er ret bred, $25-30 \mathrm{~cm}$ paa det smalleste Sted. Kammen mellem Nr. 2 og Nr. 3 har en ejendommelig blomkaalagtig Form. Den er mer end $30 \mathrm{~cm}$ bred paa det bredeste Sted, ea. $30 \mathrm{~cm}$ over Gryde Nr. 2.s Underkant. Den blomkaalsformige Del af Kammen sidder paa en faa $\mathrm{cm}$ tyk og omkring $20 \mathrm{~cm}$ høj Stilk.

Sekundær Gryde Nr. 3 er ogsaa ganske typisk. Den naar lige saa dybt ned som Nr. 2, men er noget smallere, ikke mer end $30 \mathrm{~cm}$ paa det bredeste Sted. Dens Indre er fyldt med ret fint og ganske stenfrit Sand. Man ser tydeligt, at Stenene i de smaastenede Kamme, der omgiver Gryden, staar paa Højkant.

Gryde Nr. 2 er betydelig bredere end de foregaaende. Den naar $100 \mathrm{~cm}$ ned under Mulden, og er $120-130 \mathrm{~cm}$ bred paa det bredeste Sted. Den er fyldt med rødligt, omtrent stenfrit Sand. De faa Sten i Gryden er alle tydelig rejst paa Højkant. Grydens betydelige Størrelse maa sandsynligvis skyldes, at den i Virkeligheden har Form som et Trug, der er skaaret i et ret skævt Snit af Profilvæggen. Kammen mellem Nr. 3 og Nr. 4 danner Næsens Spids, og derfor har de følgende Gryder en mere typisk Form.

Gryde Nr. 3 har typisk Form og Størrelse. Den naar mer end $100 \mathrm{~cm}$ ned under Mulden og er ca. $50 \mathrm{~cm}$ bred paa det bredeste Sted. Den er fyldt med næsten stenfrit, rødt Finsand.

Gryde Nr. 4 er kun skilt fra Nr. 3 ved en $30 \mathrm{~cm}$ høj og ved Grunden ca. $25 \mathrm{~cm}$ bred opadvendt kileformet Kam, hvori alle Stenene er rejst paa Højkant.

Brodelhorisonten fortsætter til begge Sider med mer eller mindre tydelige Gryder, som vanskeligt lader sig undersøge paa Grund af Væggens Højde. De er desuden saa utydelige, at deres Antal ikke engang kan anslaas skønsmæssigt.

I den $6 \mathrm{~m}$ høje og 40-50 m lange Østvæg ser man i den nordlige Ende ca. $2 \mathrm{~m}$ krydslejret, stenfrit Sand (Flyvesand) over ca. $4 \mathrm{~m}$ Fingrus. Herover ligger der et $10-20 \mathrm{~cm}$ mægtigt Lag af Sand uden Lagdeling, overdækket af et ca. $20 \mathrm{~cm}$ tykt Pløjelag. Længere mod Syd i Væggen ses over Flyvesandet et ret tyndt Lag af stenet Sand (Flydejord), der kiler ud til begge Sider. Heri ser man ogsaa et ret betydeligt Antal af mer eller mindre utydelige Gryder adskilte af smalle Kamme. Længst mod Syd i Væggen opnaar dette Lag en Mrgtighed af omtrent 1,50 m paa Bekostning af det fint lagdelte Flyvesand, som det tilsyneladende overlejrer konkordant. Efter at dette moræneagtige Lag har opnaaet sin største Mrgtighed i den sydlige Del af Væggen, afsmalnes det brat, idet der oven over dette Lag pludselig optræder et øvre Lag af Flyvesand med temmelig uregelmæssig, men tydelig og uforstyrret Krydslejring. Man ser følgelig 
længst mod Syd i Profilet ingen tydelig Grænse mellem det øvre og det nedre Flyvesand. Fra den nedre Spids af Morænesandskilen løber der en lang "Hale« af moræneagtigt Materiale mod Syd og adskiller paa en flere Meter lang Strækning det øvre Flyvesand fra det nedre. Denne lange mod Syd jævnt afrundede Kile af moræneagtigt Materiale er $40-50 \mathrm{~cm}$ mægtigt i Gennemsnit. Man ser i den en ret tydelig Brodelboden med smaa, kun ca. $20 \mathrm{~cm}$ brede Gryder.

\section{Brunkulgraven ved Fiskbæk.}

I Gravens Sydvæg er der i et Lag af moræneagtigt Sand, umiddelbart over Kullene. Det er ca. 0,75 m mægtigt. Grænsen mellem dette graa Sand og Brunkullene er ikke særlig skarp; thi man finder Slirer af Kul i den nederste Del af Sandet og Smører af leret Sand i den øverste Del af Kullene. Det graa Sand afsluttes opadtil af et visse Steder indtil $5 \mathrm{~cm}$ mægtigt Stenlag, bestaaende af store og smaa Sten, der regelløst er blandet mellem hinanden. Blandt Stenene fandtes mange, smukt vindslebne Kvartsiter. Over dette Stenlag ligger der ca. $1 \mathrm{~m}$ meget fint, glimmerholdigt, lagdelt Flyvesand. Det stenede, svagt lerede, graa Sand er sandsynligvis en Pseudomoræne. Ca. $10 \mathrm{~m}$ Øst for dette Profil saas da ogsaa Spor af en Brodelhorisont, bestaaende af nogle faa, men visse Steder ret tydelige Gryder, der dog laa ret spredt uden at være adskilte ved tydelige Kamme. Ved Indgravning i een af dem fandtes en utydelig Ring.

\section{Udgravninger ved Brørup.}

I Slagtermester Holst's Fenne lige Vest for den gamle Mergelgrav (A. Jessen, V. Madsen, V. Milthers og V. Nordmann, 1918) lod jeg foretage en Udgravning. Den var $0,80 \mathrm{~m}$ bred og 1,00 m lang. Længdeaksen strøg $\mathrm{S} 40^{\circ} \mathrm{V}$. Ved Nedgravningen saas nogle utydelige Ringdannelser. Det viste sig imidlertid at være umuligt at afglatte Bunden af Udgravningen, saaledes at det blev muligt at iagttage dem nøjere; thi Leret, der findes i Kammene, hænger fast i Spaden og graves derfor lettere op, mens de derved fremkomne Huller hurtigt fyldes med Sand og Grus, der falder ned fra Udgravningens Sider. Jeg lod derfor grave dybere ned i Haab om, at der vilde vise sig tydelige Gryder i vertikalt Snit i Væggene. Der saas baade i Sydøstvæggen og Nordøstvæggen en tydelig Kam, der sandsynligvis begrænser Ringe i en Brodelhorisont. Herfor taler, foruden at disse Kamme ved Indgravning i Væggen virkelig viste sig at fortsætte ind i Væggen paa samme Maade som Kammene i de andre Brodelhorisonter, ogsaa de talrige kantstillede Sten, som man ser langs deres Sider. Kammene var imidlertid saa uregelmæssige, at det ikke var muligt, paa den korte Strækning de blev udgravet, at konstatere, om de danner Ringe eller Striber. Kammen i Sydøstvæggen var den 


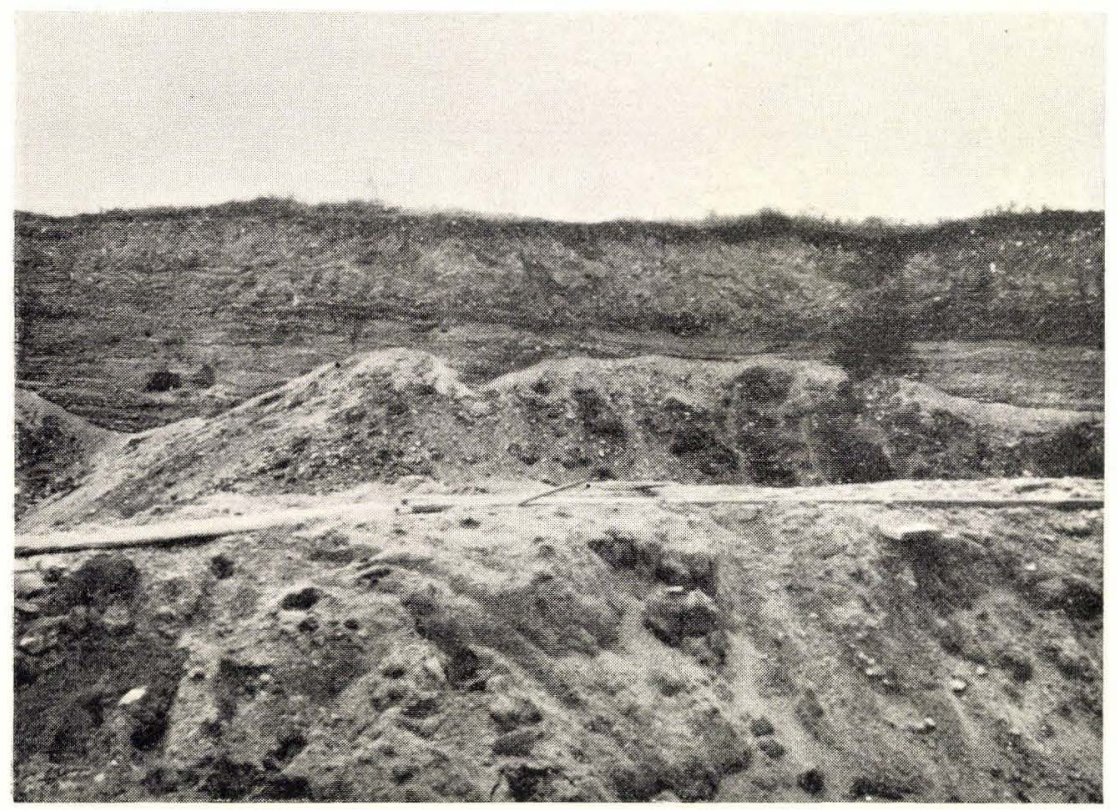

Fig. 20. Grusgrav ved Rødding. Nordvæg med Brodelhorisont.

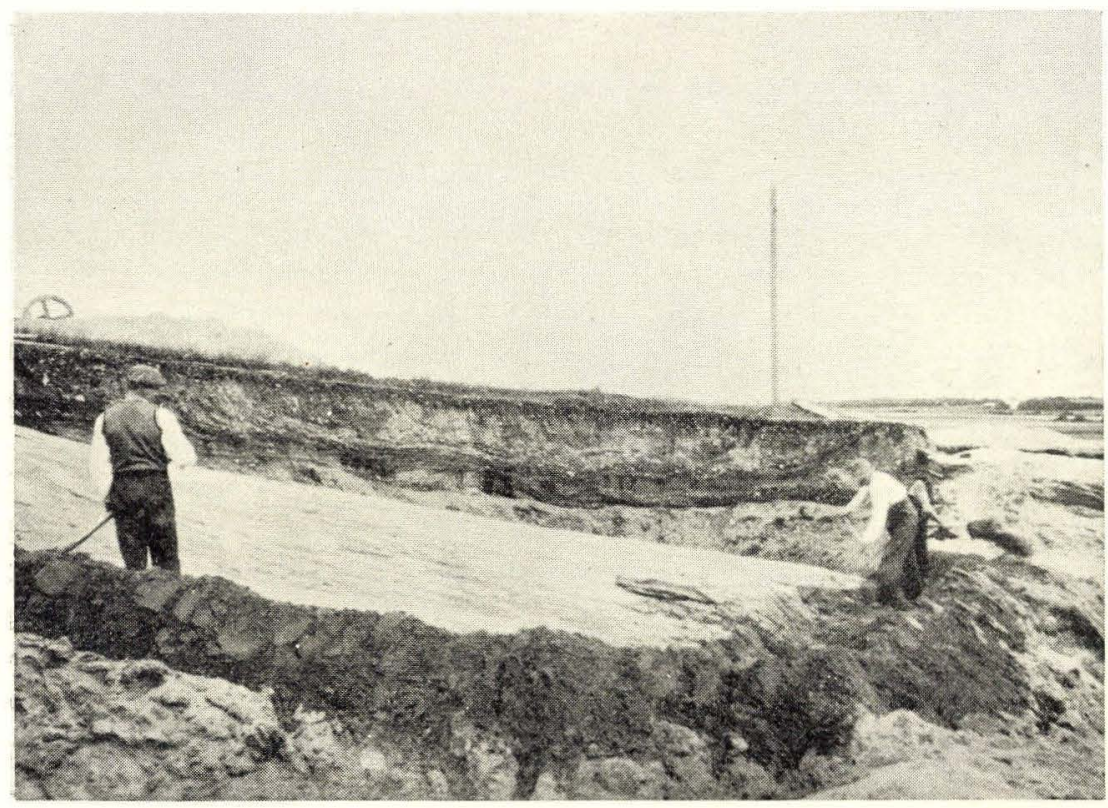

Fig. 21. Grusgrav ved Rødding. Øst- og Sydvæg. 
tydeligste; den lod sig imidlertid kun følge ca. $25 \mathrm{~cm}$ ind i Væggen. Den stryger paa denne Strækning $\mathrm{N} 50^{\circ} \varnothing$.

Ca. $60 \mathrm{~m}$ Vest for Udgravning I lod jeg foretage en anden Udgravning. Den var 1,10 m lang og lige saa bred. Den blev ført ned i en Dybde af 0,60 m. Under $25 \mathrm{~cm}$ Fyld saas fedt Ler, der sikkert oprindelig har været dækket af stenet Sand, der er fjernet ved Afrømningsarbejder i Mergelgraven. Der saas ogsaa her Strukturer, der ligner Brodelstrukturer. Den nordlige Væg i Udgravningen viste kun uregelmæssigt lejret Grus. Det havde i den øverste Halvdel en rødlig Farve. Den nedre Del af Væggen var straagul. I den østlige Væg ser man en Pose af gult Sand, nedsænket i det straagule Grus. Gryden viser Antydning til Deling i to mindre Gryder. Den nordliges Bund hæver sig stærkt indefter i Væggen og er altsaa Østende af en Gryde. Bunden af den sydlige af de to Gryder sænker sig indefter i Væggen og er altsaa den vestligste Ende af en Gryde. Lignende, men knap saa tydelige Gryder, ses baade i den sydlige og den vestlige $\mathrm{V} æ \mathrm{~g}$.

13. Grusgrav Vest for Rødding.

Vest for Rødding findes der tre Grusgrave, der ligger tæt ved Siden af hinanden, ea. $1 \mathrm{~km}$ fra Byen. Den østligste af Gravene er gravet ind i Hjortvad Aas Vestskrænt ea. 100 m Syd for Vejen, der fører fra Rødding til Hjortvad og Kalvslund. Graven er gravet i Smeltevandsgrus. Man ser i Graven en Nordvæg, der er 50—60 m lang og mer end $4 \mathrm{~m}$ høj og en Østvæg, der er ca. $30 \mathrm{~m}$ lang og $4 \mathrm{~m}$ høj i sin nordlige Del. Mod Syd bliver den, som Følge af at Graven er anlagt i en sydeksponeret Skrænt, noget lavere paa Grund af Overfladens Fald. Her drejer den jævnt om i en vestlig Retning, saaledes at der herved dannes en lille ca. $10 \mathrm{~m}$ lang og $2,5 \mathrm{~m}$ høj Sydvæg.

I Nordvæggen ligger der 1-1,5 m stærkt stenet Sand over Gruset, og i dette Sand ser man en Brodelhorisont (Fig. 20), der visse Steder er ganske smukt udviklet, uden at den dog i nogen Maade kan maale sig med de usædvanlig smukke Horisonter i Klinten ved Esbjerg og i Troldhede-Profilet.

I Østvæggen er denne Brodelhorisont temmelig utydelig; man ser kun enkelte Gryder af atypisk Form (Fig. $21 \mathrm{og} 22$ ). De er adskilte ved meget brede og uregelmæssige Kamme, der hælder noget imod Nord ned ad Skrænten. Derimod ser man nogle overordentlig smukke Gryder i den lille Sydvæg (Fig. 23).

Gry de Nr. 1 naar 50-60 cm ned under det øverste ca. $40 \mathrm{~cm}$ mægtige Lag af stenet Sand. Den er meget bred - 110-120 cm paa det bredeste Sted - men har alligevel en ganske typisk Form. Den er fyldt med smaastenet, gulligt Sand, der viser en smuk Lagdeling, konform med Grydens Inderflade. Sandet i Gryden er ret groft og indeholder kun faa Sten, der 


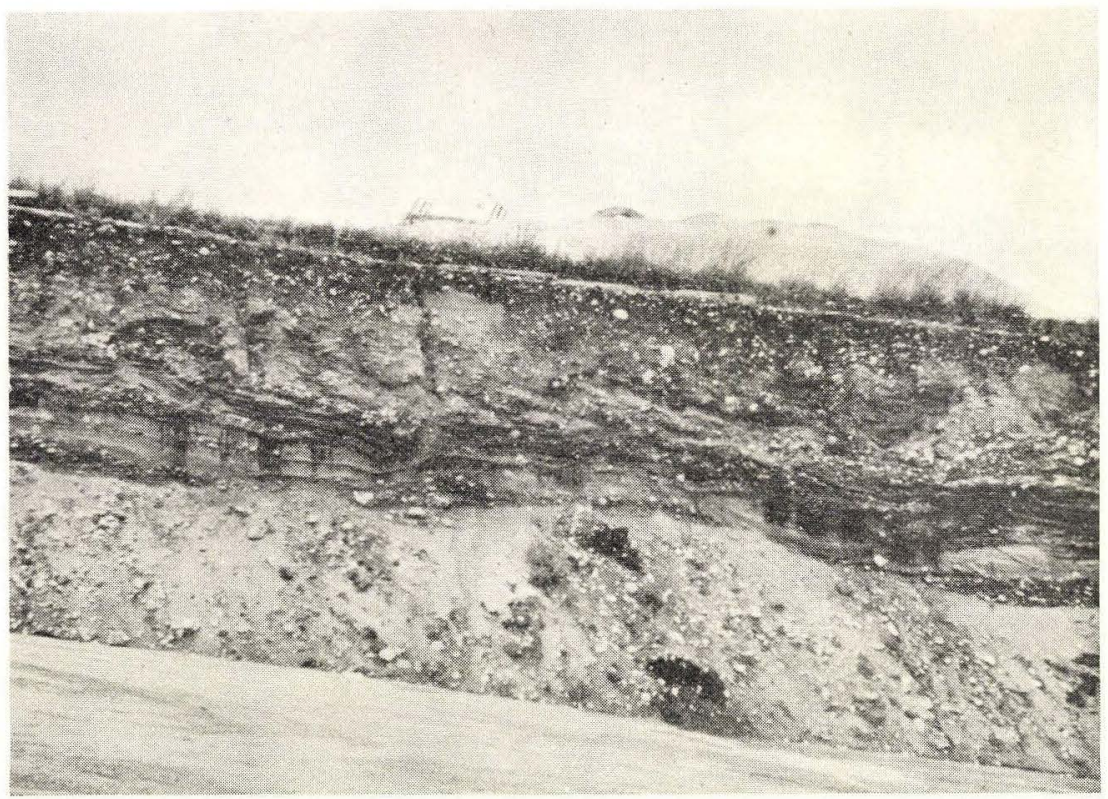

Fig. 22. Grusgrav ved Rødding. Østvæggen med den utydelige Brodelhorisont.

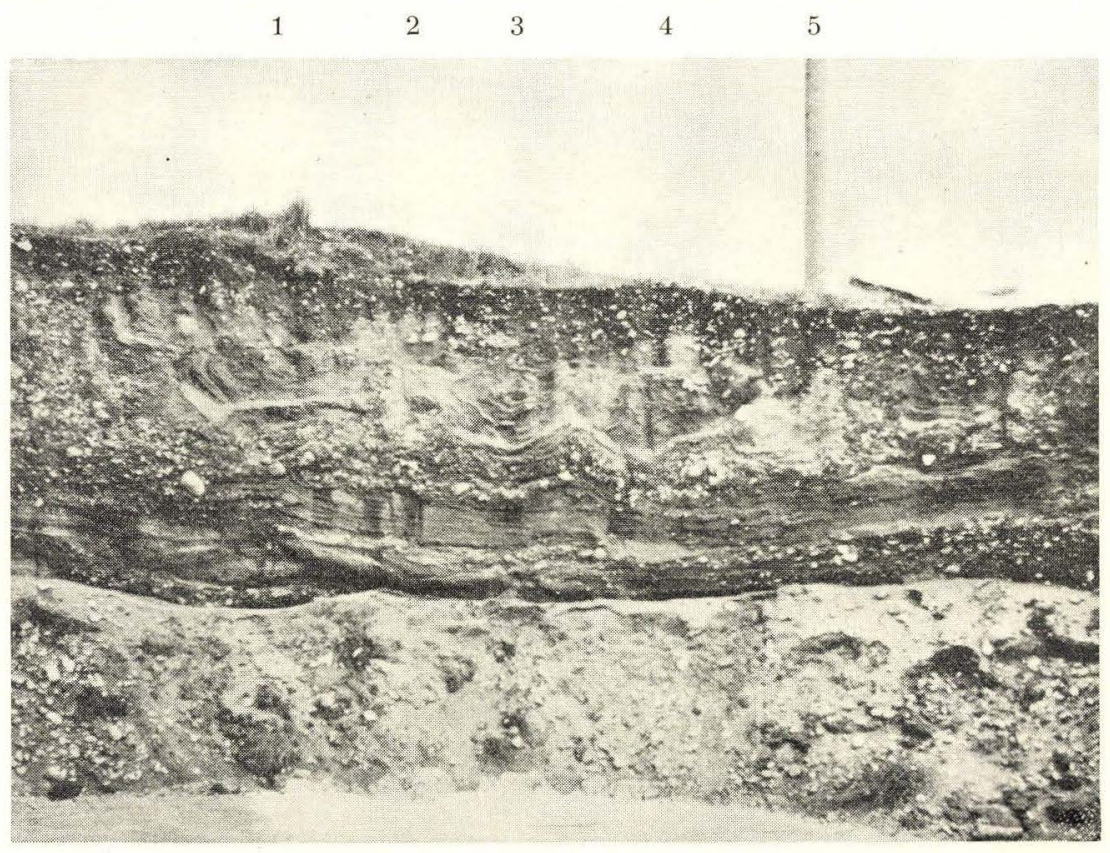

Fig. 23. Grusgrav ved Rødding. Sydvæg. Smukt udviklet Brodelhorisont. 
næsten alle er mindre end Hasselnødder, mens Stenene i de nedre Lag og i Kammene næsten alle er større end Dueæg, og mange andre endog større end en knyttet Næve.

Gryde Nr. 2 er adskilt fra Nr. 1 ved en $40 \mathrm{~cm}$ høj og ved Grunden lige saa bred, uregelmæssig, opefter tilspidset Kam af Grus, hvori alle Stenene med et Par enkelte Undtagelser er rejst paa Højkant. Den naar $60 \mathrm{~cm}$ ned under det stenede Sands Underkant, og ligger altsaa i et noget dybere Niveau end den foregaaende. Den er $60-70 \mathrm{~cm}$ bred og fyldt med rødgult, smaastenet Sand ligesom Nr. 1.

Gryde Nr. 3 er adskilt fra Nr. 2 ved en ca. $38 \mathrm{~cm}$ høj og ved Grunden $35-40 \mathrm{~cm}$ bred, opadvendt kileformet Kam af Grus. Gryden er $90 \mathrm{~cm}$ bred og naar $70 \mathrm{~cm}$ ned under det stenede Sand. Den er ret uregelmæssig, men lader sig dog tydelig erkende som en Brodelgryde, hvilket for en stor Del skyldes, at man her ser den samme karakteristiske Lejring i det indre Sand, som er iagttaget $i$ de to foregaaende Gryder.

Gryde Nr. 4 er ret utydelig og vanskelig at erkende som Gryde, som Følge af, at Kammene tilsyneladende er skredet sammen foroven, saaledes at vi her nærmest har et ret uregelmæssigt Sandparti i en ca. $100 \mathrm{~cm}$ bred Kam af Grus. I Virkeligheden drejer det sig her sikkert om Gryder af samme Art som dem, der var saa almindelige i Troldhede-Profilet, og som er betegnet Nr. 5, 7 og 12 .

Gryde Nr. 5 er atter en smuk og typisk Gryde. Den naar $30 \mathrm{~cm}$ ned under det stenede Sand og er 60-70 cm bred. Man bemærker her den samme Lejring, som fandtes i de tre først omtalte Gryder.

De øvrige Gryder i Væggen er saa utydelige, at de ikke lader sig opmaale. Det blev forsøgt at udgrave enkelte af de beskrevne Gryder, men dette blev atter opgivet, da det derved viste sig, at naar Gryderne i Profilvæggen fremtræder saa tydeligt, skyldes det, at Stenene i Kammene er skyllet rene af Regnvandet. Det viste sig ligeledes at være meget vanskeligt at følge Kammene ind i Væggen blot med nogenlunde Sikkerhed. Brodelhorisonten i Nordvæggen ligner ganske den i Sydvæggen. Dog er Nordvæggen saa stærkt tilregnet, at det ikke var muligt at udskille et bestemt Antal Gryder, selv om man hist og her ser ganske tydelige Brodelteksturer.

Den anden af de tre Grave Vest for Rødding ligger lige ved Vejen ca. $100 \mathrm{~m}$ Vest for den ovenfor omtalte Grav. Den er ogsaa ført ned i lagdelt Grus. Der er kun een Væg af Interesse, nemlig Sydvæggen. I denne $100 \mathrm{~m}$ lange, noget uregelmæssige, Væg ser man visse Steder en ret tydelig, men overalt stærkt forstyrret Brodelboden, der i Almindelighed naar ca. 1,5 m ned under Jordoverfladen. Her ligger der ogsaa øverst $25-50 \mathrm{~cm}$ stenet Sand uden tydelig Tekstur umiddelbart under det tynde Pløjelag. Gryderne er de fleste Steder fyldte med gulligt Sand, andre Steder ser man Gryder dannet i, og delvis fyldt med, Fingrus. Ved en overfladisk Betragt- 
ning af Graven lægger man kun i ringe Grad Mærke til Brodelteksturerne, men Brodelhorisonten adskiller sig tydeligt fra det nedre Sand og Fingrus ved den paafaldende Mængde af Sten, der er vendt paa Højkant.

\section{Grusgrav ved Sølsted.}

Umiddelbart vest for Hovedlandevejen fra Ribe til Tønder, omtrent midtvejs mellem Bredebro og Sølsted, hvor Vejen har et Knæk, findes der en Grav i Morænesand. Den har to Vægge, som er saa rene, at man kan gøre nogle Iagttagelser; nemlig en Vestvæg, der er 60—70 m lang og 3-4 m høj, og en Sydvæg, der er ca. $25 \mathrm{~m}$ lang og $3 \mathrm{~m}$ høj. I Morænesandet ser man en tydelig Brodelhorisont, liggende ca. $2 \mathrm{~m}$ under Jordoverfladen. Over Brodelhorisonten, der er ca. $1 \mathrm{~m}$ høj, ligger der en ca. $0,5 \mathrm{~m}$ bred Zone, der viser ret forvirrede Lejringer, som har en temmelig stor Lighed med Fluidalteksturer. Herover ligger der 0,5-1 m smukt horisontalt lagdelt Flyvesand. Den vekslende Mægtighed af Flyvesandet skyldes, at vi her i Graven ser et Snit igennem en lav Klit. Grænsen mellem Flyvesandet og de nedenunderliggende Jordlag er skarp og tydeligt markeret ved en tynd Stenhorisont.

Gryderne i Brodelhorisonten er for en stor Del meget store, mer end en Meter i Diameter, men næsten overalt ret utydelige. I Virkeligheden lader Gryderne sig kun med Sikkerhed erkende visse Steder i Væggen. De mellemliggende Partier af Brodelhorisonten viser utydelige Gryder, afvekslende med ret forvirrede Lejringer. Som Helhed er Brodelhorisonten imidlertid let kendelig paa det store Antal af kantstillede Sten. Paa denne Maade faar den visse Steder en stor Lighed med de Horisonter med utydelige Teksturer, man ser i den øverste Del af Grusaflejringer mange andre Steder i Vestjylland. Man har her Indtrykket af, at en oprindelig smuk Brodelboden er ødelagt ved senere Jordflydning. (Den øvre Horisont med den ejendommelige Fluidaltekstur). Blandt andet ser man hist og her Gryder, der gaar ca. $1 \mathrm{~m}$ dybere end den tydelige Brodelhorisont, og i en Meters Dybde under denne ser man ogsaa flere Steder uregelmæssige Sandpartier, der maaske skal tydes som en ved senere Flydning næsten fuldstændig ødelagt Brodelhorisont. Over den er der ved Jordflydning anbragt ca. $1 \mathrm{~m}$ Pseudomoræne, hvori der atter er udviklet den Brodelhorisont, der endnu fremtræder ganske tydeligt. Denne Horisont er igen blevet noget forstyrret ved Anbringelsen af det øverste Lag med de ejendommelige Fluidalteksturer. Senere er dennes øverste Del blevet afblæst, hvorved Stenhorisonten er fremkommet, og til Slut er det dækkende Lag af Flyvesand blevet anbragt over Stenhorisonten.

I Sydvæggen (Fig. 25) ser man ogsaa nogle Gryder, men de er af et saadant Format, at man vilde være tilbøjelig til at tro, de var dannet af Trykket af Indlandsisen, hvis man ikke kunde se, at Horisonten her 


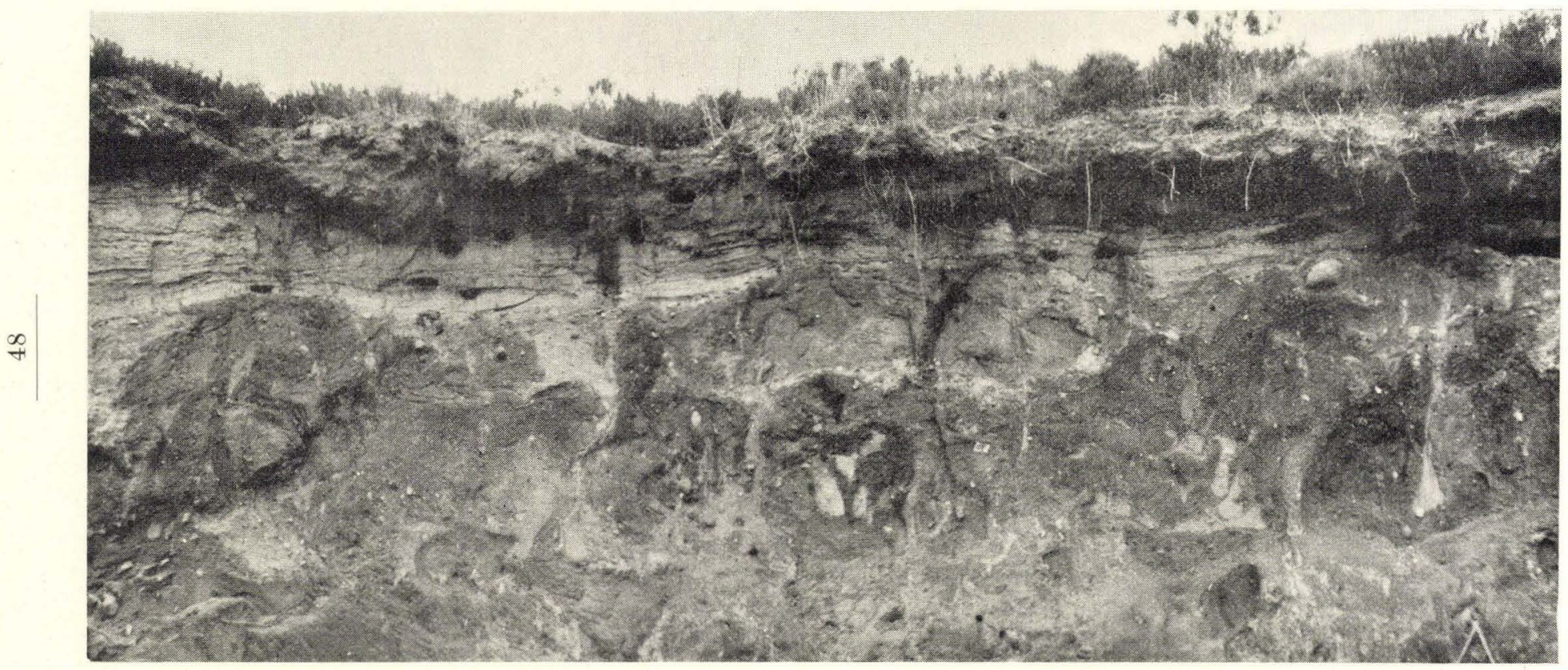

Fig. 24. Grusgrav ved Sølsted. Vestvæggen. Flydejord med udvisket Grydestruktur. 
i Sydvæggen staar i direkte Forbindelse med Brodelhorisonten i Vestvæggen. Den største Gryde maaler $120 \mathrm{~cm}$ paa sit bredeste Sted; Kammene, der adskiller Gryderne, er ca. $40 \mathrm{~cm}$ brede og dannet af ret groft Grus. Gryderne er fyldt med Sand, der viser en meget smuk Lagdeling, konform med Grydens Sider. Sandet i Gryderne indeholder kun ganske faa Sten, men Kammene er meget stenede.

Her i denne Grav danner Gryderne sikkert Stennet; thi de smaa Indskæringer paa godt 1 m's Dybde, som man ser flere Steder i Vestvæggen, viser Grydeformer paa alle deres Vægge.

\section{Grusgrav i Møgeltønder.}

I Mikkelsens Sandkule« i den vestlige Udkant af Møgeltønder ser man i den næsten fuldstændig tilskredne Vestvæg en meget utydelig Brodelboden. Væggen er ca. $30 \mathrm{~m}$ lang og $6-7 \mathrm{~m}$ høj. Den bestaar helt igennem af stærkt foldet, lagdelt Sand med spredte Sten. Over dette Sand ligger der et tyndt ca. $40 \mathrm{~cm}$ mægtigt Lag af Moræneler, overdækket af $40-$ $50 \mathrm{~cm}$ humøst Sand. Gryderne findes i den nederste Del af Moræneleret og gaar en Smule ned i det lagdelte Sand. De er $20-25 \mathrm{~cm}$ i Diameter. De fremtræder kun tydeligt et enkelt Sted i Væggen.

\section{Nørre Uttrup Teglværk.}

Tæt Nordøst for Nørre Sundby ligger der et Teglværk, hvortil man henter Leret i nogle store Grave i yngre Yoldialer noget Vest for Teglværket. Lige Syd for Teglværket er en lille Grav ført ned i Saxicavasandet, hvorfra man henter Finsand. I denne Gravs Nordvæg er der en Brodelhorisont (Fig. 26), bestaaende af 15-20 Gryder, der gennemsnitlig er $25-40 \mathrm{~cm}$ i Diameter, og som naar 60-70 cm ned under Muldens Underkant. Muldlaget øverst er mellem $40 \mathrm{og} 50 \mathrm{~cm}$ tykt. Gryderne er fyldt med ganske stenfrit Ler, og sænker sig ned i Finsandet uden at være adskilt ved egentlige Kamme. Afstanden mellem de enkelte Gryder er nemlig i de fleste Tilfælde stor, mellem $30 \mathrm{og} 50 \mathrm{~cm}$. Længst mod Ost antager de enkelte Gryder i Horisonten et ejendommeligt Udseende, idet de ligger i ret stor Afstand fra hinanden og er ganske smalle. I den vestligste af disse Gryder ser man i Grydens Bund en stor Kalkblok, $10-15 \mathrm{~cm}$ i Diameter, der udfylder den nedre Del af Gryden. Hele Gryden gør nærmest Indtryk af at være dannet ved Nedsynkning af denne Blok i Finsandet. Her i disse Gryder ser man ikke noget Tegn paa, at Kammene er dannet af oppresset Materiale; thi den utydelige Horisontallejring, der kan ses i Sandet, genfindes ogsaa i de Sandpartier, der ligger mellem Gryderne og altsaa svarer til Kammene. Længere mod Øst i 


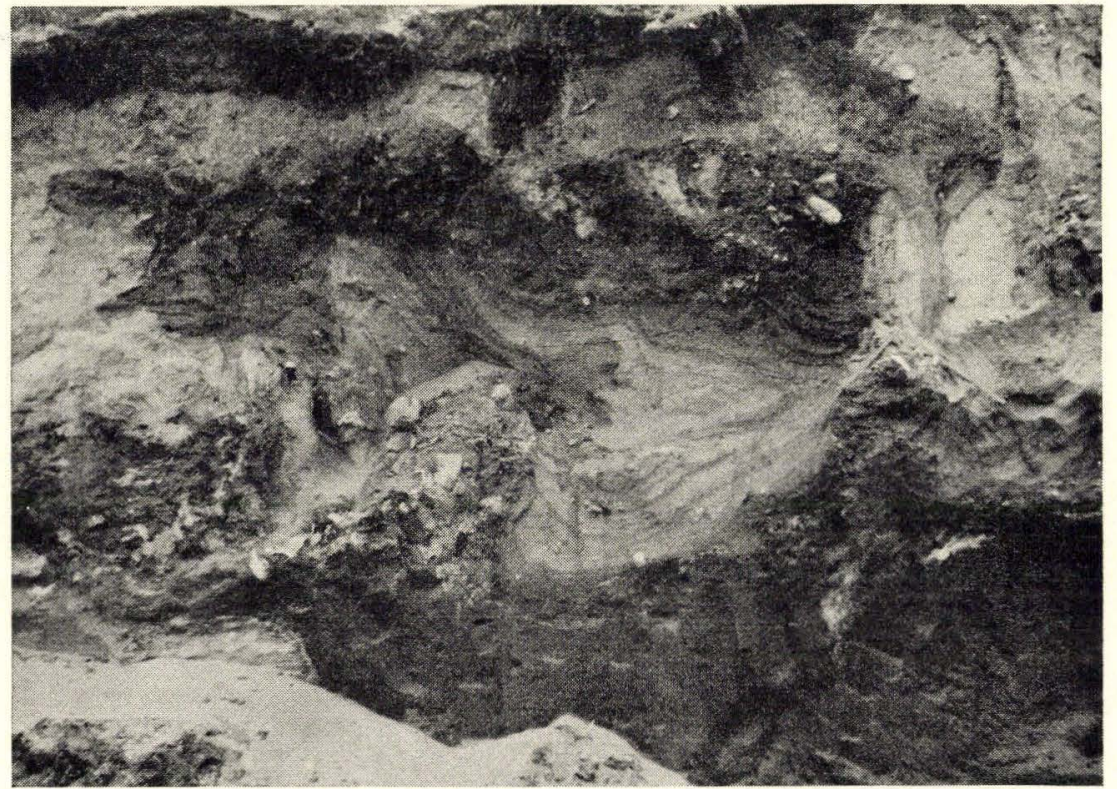

Fig. 25. Grusgrav ved Sølsted. Sydvæg. Man bemærker de store Gryder.

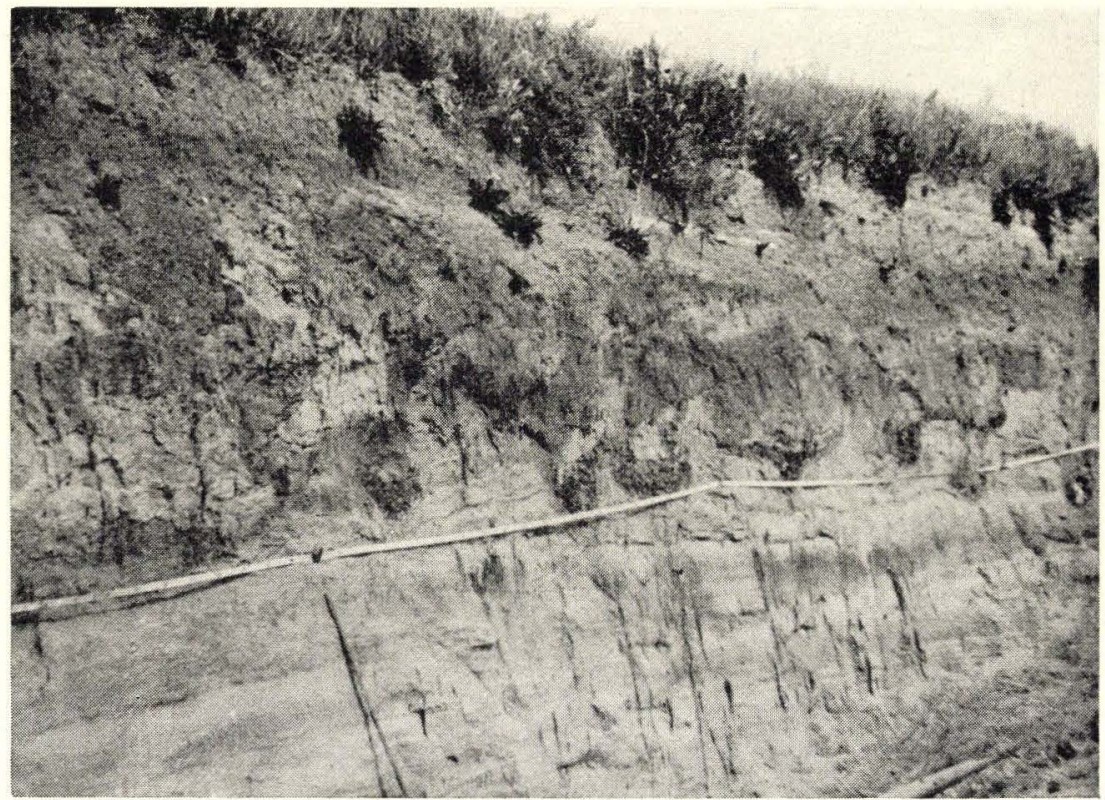

Fig. 26. Nørre Uttrup Teglværk. Nordvæg med Brodelhorisont. 
Profilet ser man flere Kalkblokke, der ligger i samme Niveau som Brodelhorisonten, men her træffer man intet Spor af nogen Grydedannelse, hverken omkring Blokkene eller imellem dem. Et Par af Gryderne blev afgravet. Herved viste det sig, at de bestaar af cylinderformede Nedposninger i Finsandet. Det viste sig dog ved Afgravningen, at der ikke støder andre Gryder umiddelbart op til de to tætliggende, der blev udgravet. Brodelhorisonten frembyder saaledes en stor Lighed med Udkanten af Brodelhorisonten i Graven tæt Nord for Troldhede og Graven ved Fiskbæk.

I de øvrige Vægge i Graven kan man se, at der tidligere er foretaget en Afgravning af de øverste Lag, hvorefter der atter er foretaget en Opfyldning med muldet Sand. Det er derfor ikke muligt at finde nogen Brodelhorisont der.

\section{Grusgrav ved Hundshoved.}

Et Par Kilometer Syd for Nørre Snede ved Hundshoved umiddelbart foran den store Israndslinie, der danner Gadbjerg-Liniens Fortsættelse mod Nord over Kollemorten til Nørre Snede findes der en lille Grav i Smeltevandssand. Her i denne Gravs lave Vægge ser man nogle ejendommelige Teksturer, som sandsynligvis skylder et eller andet Solifluktionsfænomen deres Oprindelse.

I Gravens Nordvæg, der er $23 \mathrm{~m}$ lang og $2 \mathrm{~m}$ høj, ligger der nederst lagdelt, stenet Smeltevandssand, hvoraf visse Partier endda er ganske stenfrie. Væggen var desværre for en stor Del tilskreden. Det stenede, fint lagdelte Sand er $40 \mathrm{~cm}$ mægtigt. Derover ser man i den østligste Ende af Profilet ca. $50 \mathrm{~cm}$ Grus, der ikke viser nogen tydelig Lejring, og som gaar jævnt over i stenet, leret Sand, der sender indtil $50 \mathrm{~cm}$ høje og ca. $15 \mathrm{~cm}$ brede Kamme op i det overliggende ca. $90 \mathrm{~cm}$ mægtige Lag af uregelmæssigt leret, stenet Sand. Øverst ligger der et ca. $10 \mathrm{~cm}$ mægtigt Lag af Blegsand. Disse høje Kamme danner her i Væggen 4-5 tydelige Gryder.

Umiddelbart Vest for disse Gryder ses nogle ejendommelige, blomkaalslignende Opposninger i det øverste, svagt stenede Sand, der gaar ned imellem Opposningerne som temmelig brede, svagt forgrenede Spalter, der langs Siderne er noget mere lerede. Paa denne Maade viser disse Opposninger sig ligesom overtrukne af et $0,5-1 \mathrm{~cm}$ tykt sandet Lerlag. Paa dette Sted blev der foretaget en Udgravning.

Udgravning Nr. 1 er ca. $120 \mathrm{~cm}$ bred og $140 \mathrm{~cm}$ lang. Den er ført ned i en Dybde af $75 \mathrm{~cm}$. Man ser i Udgravningen, at de blomkaalsagtige Opposninger afgravet horisontalt danner fire glatte Kupler af det tynde Lag af sandet Ler. Kuppel Nr. 1 er ca. $45 \mathrm{~cm}$ lang og $25 \mathrm{~cm}$ bred. Den naar en Højde af ca. $20 \mathrm{~cm}$. Den har Form som den ene Halvdel af en Omdrejningsellipsoide, hvis sydlige Ende er afskaaret af Profilvæggen. 
Kuppel Nr. 2 er en omtrent fuldkommen Kuglekalot. Den er ca. 20 cm i Diameter og $15 \mathrm{~cm}$ høj. Kuppel Nr. 3 er ligeledes kalotformet, men noget mer end den sydlige Halvdel af den er nu gravet bort. Den er ca. $22 \mathrm{~cm}$ i Diameter og $12 \mathrm{~cm}$ høj. Kuppel Nr. 4 er kun for en Dels Vedkommende lagt blot. Den er $20 \mathrm{~cm}$ bred og $25 \mathrm{~cm}$ lang. Dens Højde er $15 \mathrm{~cm}$.

Ca. $16 \mathrm{~m}$ herfra ser man atter utydelige Gryder i leret Grus i Væggen. Her blev der ligeledes foretaget en Udgravning.

Udgravning Nr. 2 er $160 \mathrm{~cm}$ lang og $90 \mathrm{~cm}$ bred. Den naar ca. $100 \mathrm{~cm}$ ned. Bunden af Udgravningen fik Lov til at tørre i nogle Dage, hvorefter den blev behandlet med en Pensel, hvormed Sandet i de afdækkede Gryder blev udbørstet. Kammene derimod, der bestaar af mere leret Materiale, lod sig ikke fjerne paa denne Maade. Man saa da tydeligt fem Ringe, adskilte ved ophøjede lerede Kamme, der svarede til Kammene i Gravens Vægge. Gryderne Nr 1, 2 og 3 var alle tydelige; $30-35 \mathrm{~cm}$ i Diameter og alle snittet omtrent efter Diameteren af Profilvæggen, i hvilken de ogsaa ses som ret utydelige Gryder; $10-12 \mathrm{~cm}$ brede. Gryde Nr. 4 var ca. $40 \mathrm{~cm}$ i Diameter; men er temmelig utydelig. Gryde Nr. 5 er derimod meget tydelig; ca. $35 \mathrm{~cm}$ i Diameter.

Østvæggen er meget uregelmæssig. Man ser her stærkt stenet Sand over lagdelt Grus. Grænsen imellem disse to Jordarter er det imidlertid vanskeligt at fastsætte; særlig fordi den øverste Del af Gruset ogsaa her visse Steder danner blomkaalslignende Opposninger i det stenede Sand. I den sydlige Del af Væggen og i den østlige Del af Sydvæggen ser man ligeledes utydelige Gryder af leret, stenet Materiale fyldte med stenet, lerfrit Sand. I den lille Sydvæg blev der ogsaa foretaget en lille Udgravning.

Udgravning Nr. 3 er $40 \mathrm{~cm}$ bred, $125 \mathrm{~cm}$ lang og $50 \mathrm{~cm}$ dyb. Bunden af denne Udgravning blev ogsaa børstet ren, hvorved det viste sig, at Kammene her fortsætter ind i Væggen som Striber; strygende omtrent lige Øst-Vest.

Vestvæggen er 3,5 $\mathrm{m}$ høj paa det højeste Sted og viste ca. $1 \mathrm{~m}$ sandet, vellejret Grus. Derover ligger der ea. $1 \mathrm{~m}$ Flyvesand. I det øverste Blegsand ser man en $20 \mathrm{~cm}$ bred Horisont af Flyvesand.

\section{Sandgrav ved Lundtofte, Nord-Sjælland.}

Paa Sydsiden af Vejen mellem Lundtofte og Hjortekær ligger der en Grusgrav, hvori Kastrup Glasværk henter Glassand. Over 7-8 m fint Sand med Skraalag ligger der $1 \mathrm{~m}$ Moræneler. Ca. $1 \mathrm{~m}$ under Morænens Undergrænse ser man Brodelhorisontens Overkant (Fig. 27). Selve Horisonten er ca. $30 \mathrm{~cm}$ høj. Man ser her Gryder, hvis Indre bestaar af fint Sand, der er meget uregelmæssigt lagdelt. Kammene har mer eller min- 


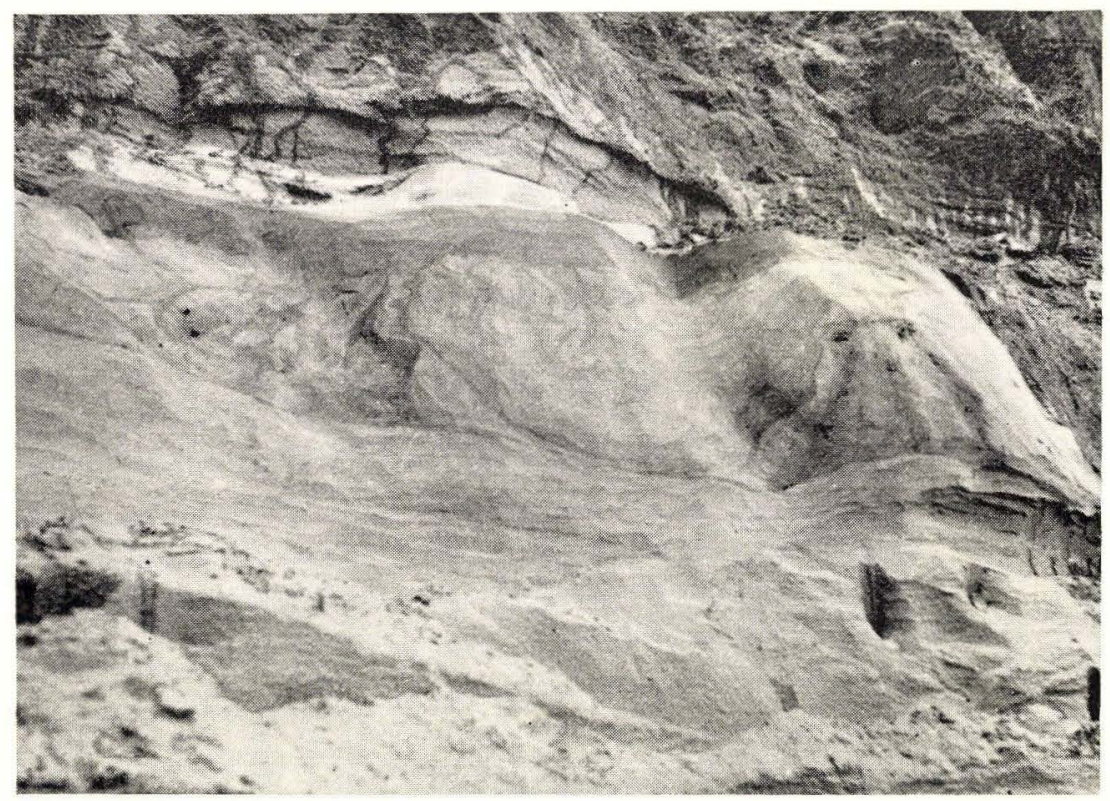

Fig. 27. Sandgrav ved Lundtofte. Man ser omtrent i Billedets Midte den tvivlsomme Brodelhorisont.

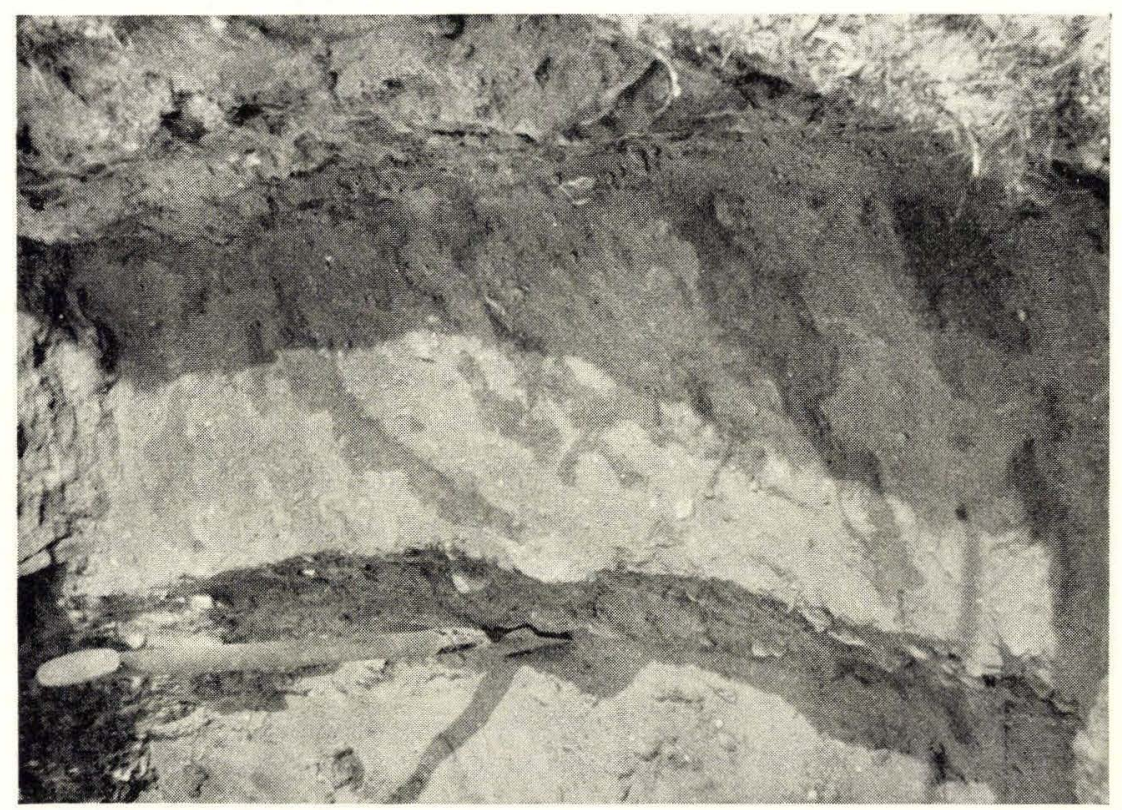

Fig. 28. Sandgrav ved Lundtofte. Horisontalsnit gennem Brodelhorisonten. 
dre Form som opadvendte Kiler. De er i Almindelighed omkring $30 \mathrm{~cm}$ høje og højst lige saa brede, for største Delen dog betydelig smallere. Fra Grydernes fine Sand var de afgrænset ved et Lerlag, der udvendig beklæder hele Kammen. Dog er det i Regelen vanskeligt at finde, hvor Kammen hører op, og det Indre af Gryden begynder, idet der i den yderste Del af Gryderne findes tynde Lerlag i Sandet, der ligger konformt med Grydernes Ydergrænse.

Nogle af Kammene blev afdækkede ved Afgravning (Fig. 28). De viste sig herved at løbe omtrent parallelt, strygende omtrent Sydøst-Nordvest. En enkelt af de afgravede Kamme delte sig indefter i to Kamme, hvoraf den ene øjensynlig et Stykke inde i Væggen sluttede sig til den nordøstlige Parallelkam. Det var imidlertid ikke muligt at forfølge Kammen til Skæringspunktet.

\section{De danske Brodelhorisonter og den arktiske Strukturmark.}

I det foregaaende Kapitel er fra forskellige Dele af Landet beskrevet en Række ejendommelige Horisonter, som alle udviser det fælles Træk, at de bestaar af grydeformede eller baadformede Nedposninger af sandet, temmelig stenfrit Materiale, adskilte ved i Almindelighed ret stenede Kamme. At dømme efter Afbildninger og Beskrivelser fra Udlandet kan der ikke herske Tvivl om, at disse Horisonter er af ganske samme Art som de, der er beskrevet fra Tyskland under Betegnelsen, Brodelhorisonter.

Siden GRIPP i 1927 forklarede saadanne ejendommelige Horisonter som Rester af en arktisk Strukturmark, har et stadig stigende Antal Forskere sluttet sig til hans Mening, uden at der dog er fremdraget ret mange nye Træk, der yderligere har kunnet bekræfte Rigtigheden af denne Opfattelse. Det vil derfor ikke være uden Betydning at tage Spørgsmaalet op til fornyet Overvejelse paa Grundlag af det Materiale, som er fremdraget her i Landet og som udgør denne Afhandling.

De danske Brodelhorisonter er alle Overfladedannelser, som, saavidt det har kunnet iagttages, findes baade paa Bakkeskrænter og i Lavninger. Dette gælder dog kun for de vestjyske Horisonter. Da alle Horisonterne - paa nær Forekomsterne i Nr. Uttrup Teglværks Grav (S. 49), ved Lundtofte (S. 52) og i Stenlille Aas (S. 12) — er fundet i Vestjylland, er denne Regel næsten almengyldig. Horisonterne ved Nr. Uttrup og ved Lundtofte afviger iøvrigt stærkt fra de vestjyske. Gryderne er mindre, 
og hverken i Gravene ved Stenlille Aas eller i Lundtofte har man kunnet udskille typiske Gryder, og selv om de omtalte Horisonter muligvis er Flydejordsdannelser, er det langt fra sikkert, at de repræsenterer en Strukturmark.

I de Tilfælde hvor man har kunnet følge den samme Brodelhorisont over tilstrækkelig store Afstande, har man iagttaget, at Brodelhorisonten ikke ændrer Udseende, selv om Underlaget skifter over til en anden Jordart. Brodelhorisonten bevarer i saadanne Tilfælde i det store og hele den samme Mægtighed, og Grydernes Størrelse er ikke afhængig af Materialets Karakter. I Klinten Øst for Esbjærg er saaledes flere af Gryderne udformet i Lag af ret groft Grus, mens andre er udviklet i fint Sand, og i Teglværksgraven Øst for Esbjærg naar Horisonten ned i det fede Yoldialer. Dette tilsammen med det ovenfor nævnte Forhold, at Brodelhorisonterne er overfladiske Dannelser, kan tyde paa, at deres Dannelse skyldes atmosfæriske Faktorer.

Undersøger man en typisk Horisont nøjere, vil man finde, at den bestaar af et enkelt Lag af gryde- eller baadformede Partier af temmelig stenfrit Sand, adskilte fra hinanden af smalle Kamme, bestaaende af det samme Materiale, som danner Horisontens Underlag og i Almindelighed beklædt med en tynd Kappe af Smaasten. Gryderne synes sjældent at være mere end $1 \mathrm{~m}$ i Diameter. Saafremt Sandpartierne er baadformede, har de i Almindelighed en lignende Bredde, mens Længden kan være forskellig i de forskellige Horisonter.

Dette svarer ganske til, hvad vi ved om Forholdene i den arktiske Strukturmark. Ogsaa den er opdelt i nogenlunde regelmæssige Polygoner af stenfrit Materiale, adskilte fra hinanden ved i Reglen stenede Kamme. Størrelsen af Gryderne i de danske Horisonter stemmer ogsaa meget godt med Størrelsesordenen af de Polygoner i den arktiske Strukturmark. Ganske vist angives Maskediameteren at være noget større i Arktis, men dette skyldes rimeligvis, at Forfatterne fortrinsvis har udvalgt Netværk med de største Ringdiametre som Eksempler. Der findes imidlertid talrige Beskrivelser af Strukturmark med mindre Ringdiametre, og det kan i hvert Fald ikke bestrides, at Ringdiametrene fra den danske Strukturmark falder inden for den normale Variation. Yderligere Undersøgelser i Arktis maa herefter afgøre, om en Ringdiameter paa 0,5 til $1 \mathrm{~m}$ er den hyppigst forekommende.

Lige som det er Tilfældet i Arktis finder man i de danske Brodelhorisonter baade Netværk af regelmæssige Polygoner, fortrukne Polygoner og Stenstriber, og ligesom i Arktis findes Stenstriberne kun paa hældende Terræn. Dette er saaledes Tilfældet i Troldhedeprofilet (S. 32) og i Grusgraven ved Rødding i Sønderjylland (S. 44). Orienteringen af Stenkammene er ogsaa fuldstændig den samme som i Arktis, idet Kammene løber nedad Skraaningen mod det laveste Niveau. 
Særlig illustrerende er Forholdene i Klinten og Teglværksgravene Øst for Esbjærg (S. 13 og 21). Ude i Klinten ser man ret stærkt fortrukne Ringe paa Overgangen til Stenstriber. Terrænets Fald er ringe, næppe til at iagttage, men paa Grund af Forekomsten af knæbøjede Lag i Klinten (S. 14) kan man slutte, at Flydejorden har bevæget sig i Forhold til sit Underlag, og at Flydningen er foregaaet i Retning mod Nord, altsaa i samme Retning som Polygonerne er udtrukket. Ved Udgravninger Nord for Klinten er der fundet fortrukne Polygoner, visende den samme Flyderetning. Længere mod Nord finder man Stenringe (S. 23), og her har Horisonten en noget større Mægtighed end ude i Klinten. Her findes aabenbart den Lavning, ned imod hvilken Flydningen er foregaaet, og som er blevet udfyldt af Flydejorden.

Stenene i Kammene vil næsten altid ligge saaledes, at den største Flade er konform med Grydens Yderflade. Af denne Grund vil de i Hovedsagen være lodretstillede i Kammenes øvre Partier. Denne Iagttagelse har en betydelig Interesse, da talrige Forfattere netop har fremhævet dette som karakteristisk for den arktiske Strukturmark.

Som tidligere omtalt (S. 55) bestaar Kammene af det samme Materiale, som danner Brodelhorisontens Underlag, og er i Almindelighed forsynet med en tynd Beklædning af Smaasten. Kammene i de Brodelhorisonter, der er beskrevet fra Udlandet, synes at være opbygget paa ganske samme Maade. Dette Forhold har WolfF (1930) og BAHr (1932) i særlig Grad været opmærksomme paa. BAHR forkaster af denne Grund GRIPPS Brodelhypotese og mener, at Kammene bestaar af Materiale, der er presset op fra Lagene under Brodelhorisonten, mens der til Gengæld er sunket Materiale ned i Grydernes Midte. I Brodelhorisonterne ved Troldhede St. og i Nr. Uttrup Teglværks Grav er det imidlertid lykkedes at iagttage en smuk Lagdeling i Kammene. Denne Lagdeling er af ganske den samme Art som Lagdelingen under Brodelhorisonterne og viser med al ønskelig Tydelighed, at Kammene er Erosionsrester. Materialet i dem har altsaa ikke været underkastet voldsomme Flytninger, og Lagdelingen er ikke blevet ødelagt ved Oppresning. Gryderne derimod maa være fremkommet ved Processer i den smukt lagdelte Serie, hvorved den oprindelige Lagdeling er blevet ødelagt, og der er sket en betydelig Tilblanding af fremmed Materiale.

Sandet i Gryderne viser ofte en smuk Lagdeling, idet Lagene ligger konformt med Grydens Inderflade, saaledes at det ser ud, som om en hel Masse stadig mindre Gryder er sat inden i hinanden. De faa Sten, der kan findes spredt i disse Sandpartier, vil ogsaa være indordnede i dette System, saaledes at deres største Flade i Almindelighed vil danne et Afsnit af en Lagflade. Stenene i den øvre Del af Gryderne vil derfor som oftest være kantstillede. Ogsaa til dette Fænomen finder man Paralleler til i den arktiske Strukturmark. Den Beskrivelse Meinardus (1912) 
giver af Stenstriberne paa Spitzbergen belyser dette særdeles vel. Beskrivelsen lyder saaledes: "Die umschlossenen Felder weichen Bodens sind oft von sekundären, bogenförmigen Strukturlinien durchzogen, deren konvexe Seite gefällwärts gerichtet ist.« _ _ — »In manchen Fällen werden diese Strukturlinien dadurch deutlicher, dass sich kleine plattige Steinchen aufrecht in der Richtung der Linien eingestellt haben.«

Man kan altsaa paavise, at Strukturen i de danske Brodelhorisonter Punkt for Punkt svarer til hvad vi kender til Forholdene i den arktiske Strukturmark, og ligesom i Arktis finder man paa Lokaliteter uden Hældning ringformede Strukturer, mens den mindste Hældning i Terrænet straks har foraarsaget en Fortrækning af Strukturen i Faldets Retning.

De fundne Horisonter med fortrukne Net og Stenstriber har ikke udmærket sig ved nogen Ejendommeligheder af særlig Interesse. Dette er derimod Tilfældet med Brodelhorisonterne, bestaaende af cirkulære Ringe. Paa alle de fundne Lokaliteter er det nemlig lykkedes at paavise, at den oprindelige Horisont er blevet mer eller mindre odelagt ved Dannelsen af een eller flere yngre Horisonter oven i den gamle. I Teglværksgraven Ost for Esbjærg er der saaledes fundet to Generationer af Gryder; i Teglværksgraven i Bramming tre og paa Lokaliteten ved Sølsted i Sønderjylland var Lejringsforholdene saa forvirrede, at det var umuligt med Sikkerhed at udskille de enkelte Horisonter. At der virkelig er Tale om flere selvstændige Horisonter udviklet oven i hinanden kan der ikke være Tvivl om. Ved Udgravning af Forekomsterne i Teglværksgraven Øst for Esbjærg og i Teglværksgraven i Bramming var de nedre Dele af hver enkelt Horisont udmærket bevaret og viste sig at bestaa af ret regelmæssige Ringe. Kun de øvre Partier af Gryderne var ødelagte ved Udformningen af nye Gryder paa et højere Niveau. Denne Iagttagelse tvinger een til den Slutning, at der er sket en Paalejring af nyt Materiale paa den gamle Strukturmark. Heri er der saa igen dannet en ny Strukturmark, og denne Proces kan have gentaget sig flere Gange, hvorved Strukturen i Flydejorden kan blive overordentlig indviklet. Det kan i første Øjeblik virke uforstaaeligt, at Horisonterne med Stenstriber og fortrukne Net aldrig har vist saadanne Forhold, mens det er Reglen, at Horisonterne med Stenringe er saaledes forstyrrede. Ved nærmere Eftertanke er det imidlertid ikke saa overraskende. Stenstriberne og de fortrukne Net er jo udformet paa Skraaninger, hvor eventuelt nytilkommet Materiale stadig flyder bort, mens Stenringene hyppigt vil være dannede i Bunden af Lavninger, hvor der intet Fald er, og hvor det Materiale, der skrider ned ad Skraaningerne, bliver aflejret.

Foruden de ovenfor omtalte arktiske Solifluktionsformer findes der endnu en Gruppe, nemlig Flydejordstungerne og Flydejordsterrasserne. Nogle af disse Fænomener (særlig visse Terrasseformer) er nært knyttet 
til Strukturmarken, af hvilke de udgør specielle Udformninger. For andres Vedkommende er Tilknytningen mere usikker (f. Eks. Flydejordstungerne); en stor Del af Fænomenerne har imidlertid næppe nogen Forbindelse med Strukturmarken. Det er imidlertid fælles for alle disse Former, at de dannes paa stærkt hældende Skraaninger. Dette er maaske Aarsagen til, at der ikke er fundet nogle af disse Former i Vestjylland, hvor Landskabsformerne er saa stærkt udjævnede. Det er imidlertid ogsaa tænkeligt, at Teksturen er blevet saa forvirret, maaske endda fuldkommen ødelagt ved den stærke Flydning, at saadanne Former under normale Omstændigheder ikke mere kan erkendes som Flydejord.

\section{De arktiske Frostfænomeners Betydning som Klimaindikatorer.}

De arktiske Frostfænomener dannes altid under ganske bestemte Klimaforhold. Naar man derfor finder Spor af saadanne Fænomener, hvor Klimaet nutildags ikke kan være Aarsagen til deres Dannelse, kan man altsaa drage visse Slutninger om, hvorledes Klimaet maa have været i tidligere Tid paa dette Sted. Forekomsten af Brodelboden viser os saaledes klart, at der har været perennerende Tæle i de isfri Omraader under den sidste Istid, eller i hvert Fald i en vis Periode af dette Tidsrum. Hvis der nemlig ikke havde været frossen Jord i en vis Dybde, som havde forhindret Nedbøren i at sive væk, kunde der ikke være udviklet Brodelboden i de øverste Partier af tykke Gruslag, som vi finder det paa Lokaliteterne ved Troldhede, Rødding og Herning.

Om Brodelhorisontens Mægtighed er identisk med den maximale Optøningsdybde, ved vi desværre ikke noget bestemt om. Der findes i den mig tilgængelige Litteratur om dette Emne ikke nogen Behandling af dette Problem, men meget tyder paa, at dette er Tilfældet i hvert Fald i de Egne, hvor man finder de meget store Strukturer udviklet. I hvert Fald angiver Brodelhorisonternes Mægtighed ubestrideligt en Minimumsværdi for denne Dybde. Nedenstaaende gives en Tabel for denne Størrelse paa de beskrevne Lokaliteter.

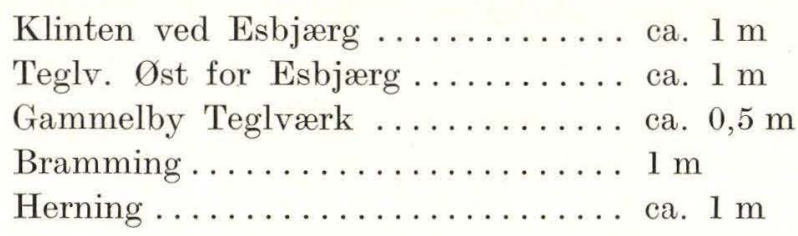




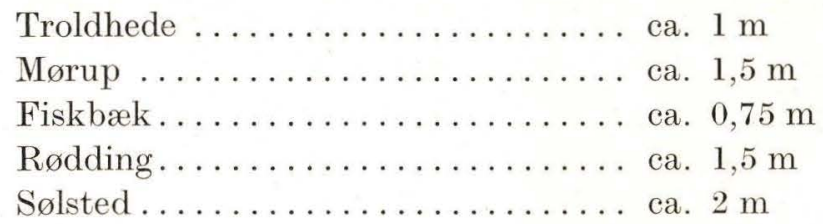

Af disse Værdier maa man imidlertid udelade dem, der stammer fra Lokaliteter, hvor man finder flere Brodelhorisonter over hinanden, herved udgaar Bramming og Sølsted af Beregningerne. Betragter man herefter Tabellen, vil man se, at langt de fleste Værdier ligger omkring $1 \mathrm{~m}$. Dette Tal maa imidlertid tages med meget Forbehold, da Optøningsdybden maa have haft forskellig Værdi, alt efter som Lokaliteten ligger paa en nord- eller sydeksponeret Skrænt. Endvidere vil Optøningsdybden i høj Grad have været afhængig af en eventuel Bevoksning, hvorom vi intet kan vide nu. Imidlertid maa man vel have Lov at henlede Opmærksomheden paa det meget interessante Faktum, at de to eneste sydeksponerede Lokaliteter, nemlig Mørup og Rødding, begge udmærker sig ved at besidde et Par af de højeste Værdier, nemlig 1,5 m.

Vi kan altsaa slutte, at der under sidste Istid - eller i hvert Fald i en vis Periode af dette Tidsrum - har været en perennerende Tæle i de Egne af Landet, hvor man finder Rester af Polygonjord. Klimaet maa derfor have været meget strengt. I det store og hele regner man med, at Betingelsen for, at der kan eksistere en perennerende Tæle, er, at den aarlige Middeltemperatur ligger lavere end $0^{\circ} \mathrm{C}$. Hvor langt under $0^{\circ} \mathrm{C}$ Middeltemperaturen har ligget, kan man ikke slutte noget om ud fra Undersøgelserne. Dybden af Tælen vil stort set være afhængig af denne Værdi, men Faktorer som Jordens Varmeledningsevne, Vegetationsdække og Overfladeform kan spille en betydelig Rolle. Desværre lader det sig jo kun gøre at danne sig et vist Begreb om Optøningsdybden, mens det ikke hidtil har været muligt at finde Spor af Tælens Undergrænse. Optøningsdybden giver imidlertid et vist Begreb om Sommertemperaturen, selv om vi ogsaa maa behandle denne Værdi med stor Forsigtighed, fordi, som tidligere nævnt, Ekspositionshjørne og Vegetation har stor Indflydelse paa denne Størrelse. Imidlertid tyder meget paa, at Optøningsdybden her i Almindelighed har ligget omkring een Meter. Dette tyder paa, selv efter arktiske Forhold, ret kølige Somre. I hvert Tilfælde maa vi regne med, at Klimaet ikke har været ekstremt tørt; thi Polygonjord synes kun at kunne udvikles i de Egne af Arktis, hvor Nedbøren ikke er ganske minimal, eller hvor der er meget Smeltevand, som har vanskeligt ved at strømme bort (Тh. Sørensen 1935).

I nogle Tilfælde er der iagttaget Tegn paa, at Brodelgryderne - ligesom det hyppigt er Tilfældet i Arktis - har været opdelt i flere mindre, sekundære Gryder. Dette er saaledes Tilfældet med enkelte Gryder i 
Klinten Ost for Esbjærg (S. 17) og i Grusgraven ved Mørup (S. 40). En saadan Opdeling af Strukturmarken i mindre Gryder skyldes ifølge Th. Sørensen, at Jordbunden er blevet mere tør. Hvorvidt dette saa igen skyldes en Klimaændring, eller kun har sin Aarsag i den Udvaskning af Kolloiderne, der ifølge Ramann (1915) finder Sted i arktiske Egne, er det $\mathrm{i}$ de fleste Tilfœlde svært at afgøre.

Af stor Interesse er Forholdet mellem Brodelhorisonterne og Frostspalterne i denne Henseende. Mens de normalt udviklede Brodelhorisonter kun findes uden for Isens Hovedopholdslinje, falder Østgrænsen for Frostspalternes største Hyppighed sammen med den østjyske Israndslinje. Alene dette viser, at Frostspalterne er et Fænomen knyttet til en Periode af Afsmeltningstiden og altsaa yngre end Strukturmarken. Dette falder godt i Traad med, at Brodelhorisonterne ved Esbjerg er gennemskaaret af Frostspalter. I Modsætning til Strukturmarken synes Frostspalterne nu til Dags kun at være almindelig udbredt i arktiske Egne, hvor Klimaet har et kontinentalt Præg. Man kan heraf slutte, at Klimaet, dengang Frostspalterne blev dannet, har haft et mere kontinentalt Præg end dengang Brodelhorisonten blev dannet.

Frostspalternes Overkant maa betegne den maksimale Optøningsdybde paa det Tidspunkt, Spalterne blev dannet. Ser vi paa Lokaliteterne Øst for Esbjerg, er det imidlertid paafaldende, at Frostspalterne tager deres Udspring i et højere Niveau end Brodelhorisontens Underkant. Optøningsdybden, dengang Frostspalterne blev dannet, maa altsaa have været mindre, end den var dengang, Brodelhorisonten blev dannet. Dette kan maaske skyldes, at Jordbunden kan have været bevokset, da Frostspalterne blev dannet, mens den utvivlsomt har været nøgen, da Brodelbevægelsen foregik. Forskellen er imidlertid saa stor, at jeg vil være tilbøjelig til at tro, at Somrene i Virkeligheden har været køligere, da Frostspalterne blev dannet. Da Klimaet utvivlsomt var blevet mere kontinentalt paa dette Tidspunkt skulde man jo endog have ventet det modsatte. Vintrene maa paa dette Tidspunkt have været meget strenge; thi Frostspalterne dannes kun i meget kolde Perioder.

Disse fremførte Paastande maa imidlertid kun betragtes som Retningslinjer for videre Arbejde. Dels er det forbundet med stort Besvær at finde tilstrækkelig mange, og tilstrækkelig gode, Profiler her i Landet alene, dels — og ikke mindst — er Forholdene i Arktis, trods en righoldig Litteratur, ikke tilstrækkelig godt undersøgte. Der er imidlertid næppe Tvivl om, at disse Fænomener vil være af Betydning for Arbejdet med at danne sig et Billede af Klimaudviklingen under Istiden. 


\section{Summary.}

\section{Some Occurrences of Arctic Soil-Polygons ("Brodelboden") Preserved in Danish Glacial Sediments.}

During the past twenty years or so several expeditions to Arctic lands have recorded observations of the peculiar Arctic solifluction phenomena ("Brodelboden" = stone rings, stone stripes etc.), whereby our knowledge of them has been greatly increased. As northern Europe had an Arctic climate during certain parts of the Glacial Age, the question naturally arises whether similar processes did not take place in the soil of Denmark, and if so, whether they left no trace behind them. In actual fact, curious textures have been found in the upper strata of European countries, textures which are regarded as remains of Arctic soil-polygons (Gripp 1927; WolfF 1927, 1930; KeILHACK 1927; Firbas \& Graham 1928; Krekeler 1929; Bennhold 1929; Becksmann 1931; Schultz 1931; Beschoren 1931; Pfuhl 1932; Bahr 1932; Dǘcker 1933; Gellert 1933; Richter 1933; Wittmann 1936; Edelman, Florschütz \& Jeswiet 1936; Bigot 1928, 1930, 1931, 1935; Milon \& BerTHOIS 1930).

Several localities with such phenomena have also been discovered in Denmark. At several places, mainly in Jutland (Esbjerg, Bramming, Herning, Troldhede, Mørup, Rødding, Sølsted, Nr. Uttrup etc.) pockets of stoney sand have been found in gravel or clay. These pocket horizons have features that conform closely with the recent soil-polygons. They are all surface phenomena, and they occur in both hill slopes and depressions. Where it is possible to trace the same horizon for a sufficient distance it has been proved that the horizon does not change in appearance even if the nature of the substratum becomes another. The typical horizon consists of a single stratum of kettle or boatshaped pockets of almost stoneless sand, separated by narrow ridges consisting of the same material as that forming the substratum of the horizon and usually having a plaster of small stones. In these Danish brodel-horizons as in the Arctic we find a network of regular polygons, distorted polygons and stoney stripes, and likewise the stoney stripes occur in dipping terrain. The orientation of the stoney ridges is also exactly the same as in the Arctic, for they run down the slope towards the lowest level.

Conditions in the cliff and the brickworks pits east of Esbjerg are particularly illustrative. In the cliff there are greatly distorted rings at the transition to stone stripes. The fall of the ground is slight, in fact scarcely observable; but on account of the presence of drag it is possible to conclude that the flow-earth has moved in relation to its substratum and that the flow proceeded north- 
wards, that is to say in the same direction as that in which the polygons are drawn out. Excavations north of the cliff have revealed distorted polygons exhibiting the same direction of flow. Farther north one finds stone rings, and there the horizon is somewhat thicker than in the cliff. Here evidently is the depression down to which the flow proceeded and which was filled with the flowearth.

In almost all cases the stones in the ridges lie with the greatest surface conformable with the outer surface of the depression. For this reason they are mainly vertical in the upper parts of the ridges. This observation is of particular interest, as many authors have pointed it out as being characteristic of the Arctic.

As already stated, the ridges consist of the same materials as those which form the substratum of the brodel-horizon, and they usually have a thin covering of small stones. Ridges in brodel-horizons described abroad seem to be built up in exactly the same manner. WolfF (1930) and BAHR (1932) in particular had observed this. For this reason BAHr rejects Gripp's brodelhypothesis and considers that the ridges consist of materials that have been pressed up from the deposits under the brodel-horizon, and at the same time materials have fallen into the middle of the depressions. However, in the brodel-horizons at Troldhede Station and in the brickworks pit at Nr. Uttrup a distinct stratification has been observed in the ridges. This stratification is of exactly the same kind as that under the brodel-horizons and is adequate evidence of the fact that the ridges are remnants of the original rock. Accordingly, the material in them was not subjected to flow and the bedding was not deformed by up-thrust. On the contrary, the depressions must have been formed by processes in the original, well-stratified series which destroyed the stratification, and a considerable admixture of extraneous material took place.

The sand in the depressions is often well stratified with the beds conforming to the inner surface of the depression, giving the impression of a large number of ever-smaller "basins" being nested one within the other. The very few stones scattered about in these sandy layers are also coordinated in the system, their greatest surface usually forming part of the plane of a stratum. As a consequence, the stones in the upper part of a depression will usually stand on edge. This phenomenon too is paralleled in the Arctic soil-polygons. The description given of the stone stripes on Spitzbergen by Meinardus (1912) illustrates this very well. The description runs as follows: "Die umschlossenen Felder weichen Bodens sind oft von sekundären, bogenförmigen Strukturlinien durchzogen, deren konvexe Seite gefällwärtz gerichtet ist." — "In manchen Fällen werden diese Strukturlinien dadurch deutlicher, dass sich kleine plattige Steinchen aufrecht in der Richtung der Linien eingestellt haben."

The irregular reticulations and the stone stripes are always situated on the slopes, whereas the horizons with circular rings always occur in the depressions, for which reason the latter horizons are nearly always more or less destroyed, flow-earth from higher levels having been deposited on the original horizon. Then another depression developed in the new deposit. If this process was repeated several times it will no longer be possible to distinguish the various horizons.

The occurrence of brodelboden in Danish glacial deposits shows that in those days the country had a perennial "tjäle" like that of Arctic lands nowadays. It is beyond doubt that the thickness of the brodel-horizons represent a minimum value of the depth thawed out in summer at the time 
the brodel-process was going on. The following values have been measured at various places in Jutland: the cliff at Esbjerg, about 1 metre; the brickworks pit east of Esbjerg, about $1 \mathrm{~m}$; Gammelby brickworks east of Esbjerg, about $0.5 \mathrm{~m}$; Bramming, about $1 \mathrm{~m}$; Herning, about $1 \mathrm{~m}$; Troldhede, about $1 \mathrm{~m}$; Mørup, about $1.5 \mathrm{~m}$; Fiskbæk, about $0.75 \mathrm{~m}$; Rødding, about $1.5 \mathrm{~m}$; Sølsted, up to about $2 \mathrm{~m}$. These values, however, must be treated with great caution, as they may have been influenced considerably by exposure and vegetation. Nevertheless, the slight depth of thaw-even according to Arctic standards - suggests rather cold summers. At this time the climate cannot have been extremely dry, for polygon-soil seems to develop only in those parts of the Arctic where precipitation is not quite minimal, or where there is much meltwater which has difficulty in draining off (Тн. SørEnsen 1936). In some instances there are signs that the brodel-depressions were divided up into smaller, secondary depressions, as is often the case in the Arctic. According to Sørensen this division is due to the soil having become drier. Whether this is due to a change in the climate or merely to the washing out of the colloids which, according to RAMANN (1915) takes place in Arctic regions, is difficult to decide.

Normally developed brodel-horizons seem to occur chiefly in regions that were ice-free during the last glacial period. This strongly suggests that they were formed during that period. The frost fissures, on the other hand, seem to have been formed during a phase of the waning period (NøRvang 1942). This agrees very well with the fact that the frost fissures east of Esbjerg cut through the brodel-horizon. Nowadays these frost fissures seem to occur in Arctic regions with an extremely severe climate, which indicates that the climate became more severe towards the close of the glacial age; even the summers seem to have been colder at this juncture, for the upper edges of the frost fissures, which presumably represent the maximum depth of the summer thaw, lie higher than the lower edge of the brodel-horizons at this spot. 


\section{Litteraturliste.}

Andersen, S. A., 1931: Om Aase og Terrasser inden for Susaa's Vandomraade. D. G. U. II. R. Nr. 54 .

Bahr, A., 1932: Frostgestauchte Böden im westlichen Schleswig-Holstein. Zeitschr. Deutsch. Geol. Ges. 84.

Becksmann, E., 1931: Fossile Brodelböden im Profil des Roten Kliffs (Sylt). Neues Jahrb. f. Min. etc. 66 B.

Bennhold, W., 1929: Ueber Fliesserdeerscheinungen in unterdiluvialen Sanden bei Wernsdorf. Zeitschr. f. Geschiebeforsch. 5.

Benz, A., 1930: Tertiär und Diluvium in westfälisch-holländischen Grenzgebiet. Zeitschr. Deutsch. Geol. Ges. 82.

Beschoren, B., 1931: Über einheimisches Diluvium in der Umgebung von Burgdorf in Hannover. Jahrbuch d. Preuss. Geol. Landesanst. für 1931. 52.

Bigot, A., 1930: Les terrasses pléistocéne du littoral du Cotentin. Livre Jubilaire du Centenaire de la Société géologique de France. 1.

- 1932: Rôle de la solifluxion. Comptes Rendus Acad. Science Paris. 195.

- 1934: La terrasse littorale de Vasouy (Calvados). Comptes Rendus somm. Séances. Soc. Géol. France.

- 1935: Pléistocène des Iles Anglo-Normandes. Comptes Rendus somm. Séances Soc. Géol. France.

- 1937: Bibliographie analytique sur des travaux de la solifluxion dans le NordOuest de la France.

Dücker, A., 1933: Steinsohle oder Brodelpflaster? Centralbl. f. Min. B.

Edelman, C. H., F. Florschütz \& J. Jeswiet, 1936: Über spätpleistozäne und frühholozäne, kryoturbate Ablagerungen in den östlichen Niederlanden. Verh. Geol.Mijnbouwk. Genootschap Nederland en Koloniën.

Firbas, F. \& R. Grahmann, 1928: Ueber jungdiluviale und alluviale Torflager in der Grube Marga bei Senftenberg (Niederlausitz). Abh. Math. Phys. Klasse Sächs. Acad. d. Wiss. 40 (4).

Gallwitz, H., 1937: Fliesserde und Frostspalten als Zeitmarken. Geol. Rundschau 28 (8).

Gellert, J. F., 1933: Diluvialer Frostboden in Oberbaden. Zeitschr. Deutschen Geol. Ges. 85.

GripP, K., 1927: Beiträge zur Geologie von Spitzbergen. Naturw. Ver. in Hamburg 21 $(2-4)$.

- 1929: Glaciologische und geologische Ergebnisse der Hamburgischen Spitzbergenexpedition 1927. Naturw. Ver. in Hamburg. 22 (2-4).

Horn, E., 1912: Die geologischen Aufschlüsse des Stadtparkes am Winterhude. Zeitschr. Deutsch. Geol. Ges. 64 MB. 
Jessen, A., 1922: Geologisk Kort over Danmark. Kortbladet Varde. D. G. U. I. R. Nr. 14 .

- , V. Madsen, V. Milthers \& V. Nordmann, 1918: Brorup-Mosernes Lejringsforhold. D. G. U. IV. R. Bd. 1 Nr. 9.

Jessen, K. \& V. Milthers, 1928: Stratigraphical and palaeontological studies of Interglacial Freshwater Deposits. D. G. U. II. Rk. Nr. 48.

Keilhack, K., 1927: Ueber Brodelböden im Taldiluvium bei Senftenberg. Zeitschr. Deutsch. Geol. Ges. 79 MB.

Kessler, P., 1925: Das eiszeitliche Klima. Stuttgart.

Krekeler, F., 1929: Fossile Strukturböden aus der Umgebung von Giessen in Wiesbaden. Zeitschr. Deutsch. Geol. Ges. 81.

LoRié, J., 1892: Les phènoménes pseudo-glaciaires en Hollande. Arch. Mus. Teyler Sér. II 3.

Meinardus, W., 1912: Über einige charakteristische Bodenformen auf Spitzbergen. Sitz.Ber. d. Mediz. naturw. Ges. zu Münster.

Nørvang, A., 1942: Frostspalter i Jylland. Medd. Dansk Geol. Foren. 10 (2).

Mrlon, Y., 1933: L’influence de la solifluxion. Comptes Rendus sommaire Séances Soc. Géol. France.

- \& L. Berthois, 1930: Étude préliminaire des formations quaternaire de Brignogan (Finistère). Comptes Rendus sommaire Soc. Géol. France.

- \& L. Dangeard, 1928: Sur l'importance des phénomènes de solifluxion en Bretagne. Comptes Rendus Acad. Science. Paris. 187.

Pfunl, E., 1932: Ueber die Schichtenstörungen in den untersten Sanden der Tongruben von Glindow. Zeitschr. f. Geschiebeforsch. 8.

Ramann, E., 1886: Der Ortstein und ähnliche Secundärbildungen in den Diluvial- und Alluvialsanden. Jahrbuch d. Preuss. Geol. Landesaust. f. 1885.

—, 1915: Die Einwirkung elektrolytarmer Wasser auf diluviale Ablagerungen und Böden. Zeitschr. Deutsch. Geol. Ges. 67.

Richter, K., 1933: Gefüge und Zusammensetzung des norddeutschen Jungmoränen. Zeitschr. f. Geschiebeforschung. Beiheft.

Sснмірт, K., 1933: Zur Kenntnis der periglacialen Ablagerungen in Mittelfranken. Diss. Erlangen.

Schröder, H. \& J. Stoller, 1905: Wirbeltierskelette aus den Torfen von Klinge bei Kottbus. Jahrbuch d. Preuss. Geol. Landesaust. f. 1905.

Schultz, O., 1931: Ueber Brodeltexturen in subglacialen Sanden. Zeitschr. f. Geschiebeforsch. 7 .

Steenstrup, K. J. V., 1897: Jordskælvsspalter? Medd. Dansk Geol. Foren. Nr. 4.

Sørensen, Tн., 1935: Bodenformen und Pflanzendecke in Nordostgrönland. Medd. om Grønland 93 (4).

Wittman, O., 1936: Diluvialprofile mit periglazialen Erscheinungen im Douaugebiet. Jahresber. Mitt. d. Oberrhein. geol. Ver. N. F. 25.

WolfF, W., 1927: Einige glazialgeologische Probleme aus dem norddeutschen Flachlande. Zeitschr. Deutsch. Geol. Ges. 79 MB.

- 1930: Die Bodenbildungen Schleswig-Holstein und ihr Verhältnis zu den geol. Bodenarten. Jahrb. Preuss. Geol. Landesanst. 51. 

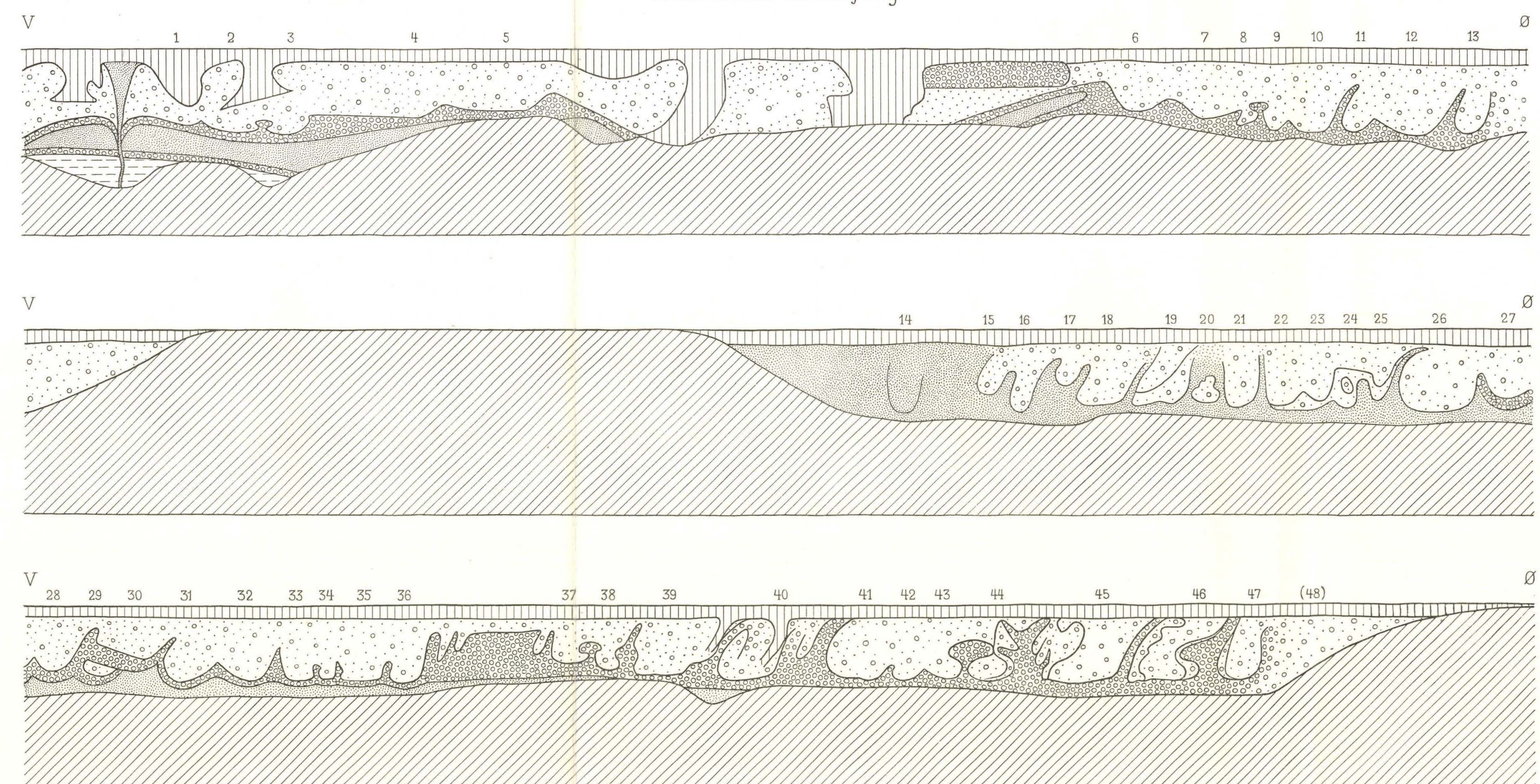

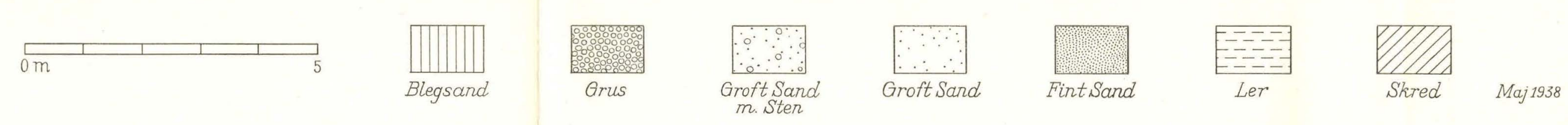


FR. BAGGES KGI. HOFBOGTRYKKERI KØBENHAVN 